WSRC-TR-96-0324

\title{
GROUNDWATER MONITORING PROGRAM EVALUATION FOR A/M AREA, SAVANNAH RIVER SITE
}

\author{
R.A. Hiergesell \\ SRTC/ESS \\ J.S. Bollinger \\ SRTC/ATS
}

\section{DISCLAIMER}

This report was prepared as an account of work sponsored by an agency of the United States Government. Neither the United States Government nor any agency thereof, nor any of their employees, makes any warranty, express or implied, or assumes any legal liability or responsibility for the accuracy, completeness, or usefulness of any information, apparatus, product, or process disclosed, or represents that its use would not infringe privately owned rights. Reference herein to any specific commercial product, process, or service by trade name, trademark, manufacturer, or otherwise does not necessarily constitute or imply its endorsement, recommendation, or favoring by the United States Government or any agency thereof. The views and opinions of authors expressed herein do not necessarily state or reflect those of the United States Government or any agency thereof.

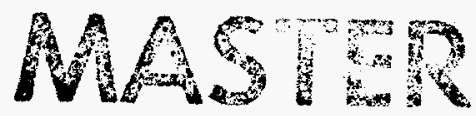

Westinghouse Savannah River Company

Savannah River Site

Aiken, SC 29808 
DISCLAIMER

Portions of this document may be illegible in electronic image products. Images are produced from the best available original document. 


\section{TABLE OF CONTENTS}

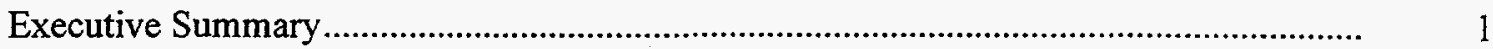

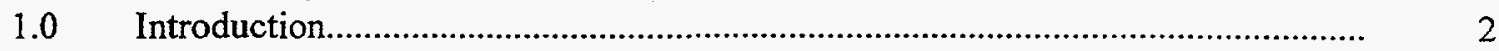

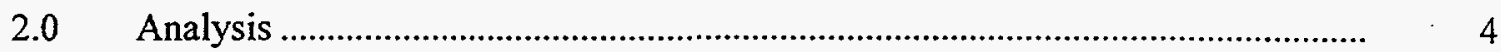

$2.1 \quad$ Hydrogeologic model .......................................................................... 4

2.2 Geographic Information System Analysis ............................................. 5

$2.3 \quad$ Evaluation ............................................................................................. 7

2.3.1 Well integrity and sample reliability........................................ 12

2.3.2 Strategic location ................................................................ 15

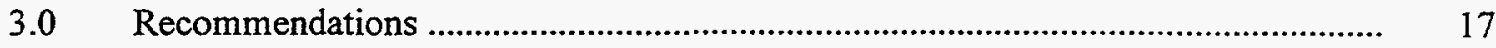

3.1 Recommendations relating to well integrity ............................................ 17

3.2 Recommendations relating to well location .................................................. 18

3.3 Recommendations for further GIS development ...................................... 18

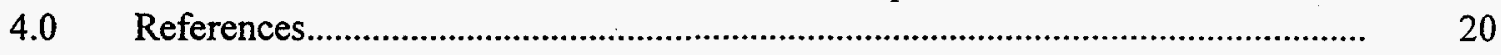

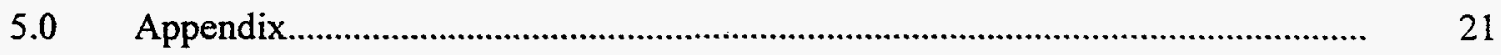

\section{LIST OF FIGURES}

Figure $\quad 1$ TCE concentration in wells finished in the M-Area Aquifer ...................... 8

Figure 2 PCE concentration in wells finished in the M-Area Aquifer ..................... 9

Figure 3 TCE concentration in wells finished in the Lost Lake Aquifer .................. 10

Figure $\quad 4 \quad$ PCE concentration in wells finished in the Lost Lake Aquifer ................... 11

\section{LIST OF TABLES}

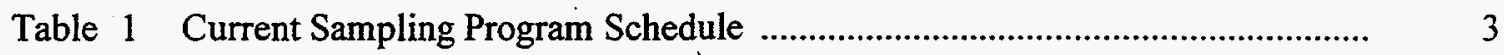

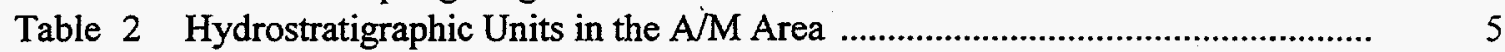

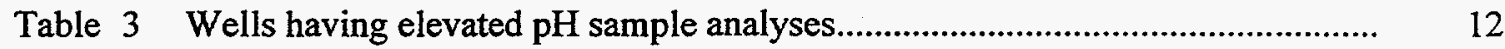

Table 4 Wells having elevated turbidity in samples .........................................................

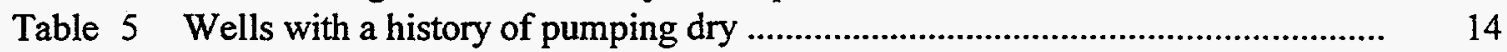

Table 6 Wells which apparently breach a confining unit ...............................................

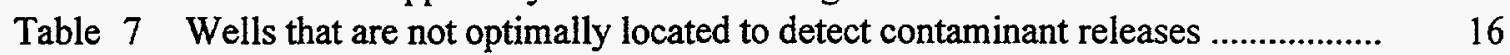

Table A Master list of wells in the A/M Area .............................................................. 22

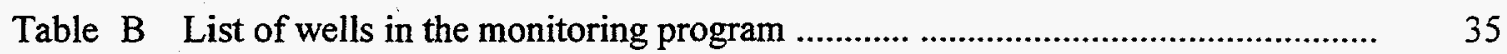

Table C Partial list of annular materials ARC/INFO coverage point attribute ................. 46

Table D Partial listing of screen zone ARC/INFO coverage point attribute table ............ 49

Table E Description of attributes for the screen zone coverage point attribute table ...... 52

Table F Description of attributes for the annular material coverage point attribute table

Table G Partial listing of records for combined annular materials .............................. 58

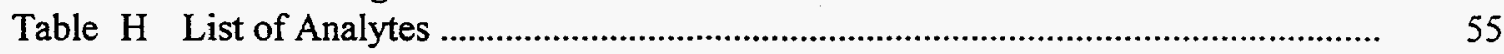




\section{GROUNDWATER MONITORING PROGRAM EVALUATION FOR A/M AREA}

\section{EXECUTIVE SUMMARY}

This investigation was undertaken with the primary purpose of assessing the groundwater monitoring program within the A/M Area to identify ways in which the monitoring program could be improved. The task was difficult due to the large number of wells located within the A/M Area and the huge database of analytical data. It was recognized early in this investigation that one of the key tasks was to develop a way to gain access to the groundwater databases so that recommendations could be made. To achieve this, geographic information systems (GIS) technology was used to extract pertinent groundwater quality information from the Geochemical Information Management System (GIMS) groundwater database and display the extracted information spatially. GIS technology was also used to determine the location of well screen and annular material zones within the $\mathrm{A} / \mathrm{M}$ Area hydrostratigraphy and to identify wells that may breach confining units. Recommendations developed from this study address:

- wells that may not be providing reliable data but continue to be routinely sampled.

- wells that may be inappropriately located but continue to be routinely sampled.

- further work that should be undertaken, including well development, evaluation of wells that may be breaching confining units, and development of an automated link to GIMS using GIS so that GIMS data can easily be accessed and displayed geographically. 


\subsection{INTRODUCTION}

Within the A/M Area, groundwater monitoring is conducted primarily for the purpose of maintaining compliance of the Savannah River Site (SRS) with the RCRA and other associated South Carolina regulations. The types of wells that are monitored for compliance are the Point of Compliance (POC) wells, generally located close to individual disposal facilities and the background (BG) wells. Groundwater monitoring is also conducted in other wells to monitor the effectiveness of corrective actions currently being undertaken within the $\mathrm{A} / \mathrm{M}$ Area. These wells include plume definition (PDW) wells and recovery wells. Other types of wells in the A/M Area include special investigation wells (SP) and production wells (PW).

The wells in the groundwater monitoring program were installed to monitor for possible environmental impacts resulting from the disposal of contaminants in various disposal facilities near the A/M Area. Each series of wells is assigned a well series name to link it with the disposal facility it was installed to monitor. The well series names are listed below and the full name of the associated disposal facility is provided for each. Only the AC wells are not specifically linked to a disposal facility.

$\begin{array}{ll}\text { ABP } & \text { A-Area Metals Burning Pits } \\ \text { AC } & \text { A-Area Cluster Perimeter Wells } \\ \text { ACB } & \text { A-Area Coal Pile Runoff Containment Basin } \\ \text { AMB } & \text { Metallurgical Laboratory Seepage Basin } \\ \text { AOB } & \text { Motor Shop Oil Basin } \\ \text { ARP } & \text { A-Area Burning Rubble Pits } \\ \text { ASB } & \text { Savannah River Lab Seepage Basins } \\ \text { MCB } & \text { Miscellaneous Chemical Basin } \\ \text { MSB } & \text { M-Area HWMF Wells: Plume definition wells } \\ \text { SRW } & \text { Silverton Road Waste Site }\end{array}$

Each of the well types described above are monitored for different analyte suites and at different times of the year. The analyte suites which are conducted include the Groundwater Protection Standard (GWPS) analyses, Monitoring Constituent Standard (MCS) analyses, and Appendix IX Parameters, Polychlorinated Biphenyls (PBC's). Additionally, Field Parameters and Synchronous Water Levels are obtained. The schedule for collecting each of the sample suites, by well type is presented below in Table 1, Current Sampling Program. A list of the analytes associated with each sample analysis suite (with the exception of the Appendix IX suite, is presented below Table 1 . 
Table 1. Current Sampling Program Schedule

\begin{tabular}{|c|c|c|c|c|c|c|c|}
\hline Well Type & $\begin{array}{l}\text { Synchronous } \\
\text { Water Levels }\end{array}$ & $\begin{array}{l}\text { Field } \\
\text { Parameters }\end{array}$ & GWPS & PCB's & $\begin{array}{l}\text { Appendix } \\
\text { IX }\end{array}$ & MCS & $\begin{array}{l}\text { Radiological } \\
\text { Indicators }\end{array}$ \\
\hline Piezometers & Quarterly & & & & & & \\
\hline POC & Quarterly & $\overline{1 Q, 3 Q}$ & $1 Q, 3 Q$ & $1 Q, 3 Q$ & $20 \%, 3 \mathrm{Q}$ & $3 Q$ & $3 Q$ \\
\hline $\mathrm{BG}$ & Quarterly & $1 \mathrm{Q}, 3 \mathrm{Q}$ & $1 Q, 3 Q$ & & & $3 Q$ & $3 Q$ \\
\hline PDW & Quarterly & 10,30 & $1 \mathrm{Q}, 3 \mathrm{Q}$ & $1 \mathrm{Q}, 3 \mathrm{Q}$ & & $3 Q$ & $3 Q$ \\
\hline Recovery & Monthly & Monthly & Monthly & $1 Q, 3 Q$ & & & \\
\hline & & & (organics) & & & & \\
\hline New Wells & Quarterly & Quarterly & Quarterly & & & Quarterly & \\
\hline & & & & & & & \\
\hline
\end{tabular}

1Q - First Quarter; 3Q - Third Quarter; PCB's - Polychlorinated Biphenyls; GWPS - Groundwater Protection Standard; MCS Monitoring Constituents Standard; POC - Point of Compliance Well; BG - Background Well; PDW - Plume Definition Well

Field Parameters: $\quad \mathrm{pH}$, specific conductance, temperature, alkalinity, water level, turbidity

Appendix IX: $\quad$ EPA list, presented in many references. Included in DPST-87-667

GWPS:

$\mathrm{Ba}$, cyanide, $\mathrm{Pb}, \mathrm{Ni}$, Se, chlorobenzene, 1,1-dichloroethane, 1,1-dichloroethylene, 1,2dichloroethylene, PCB's, 1,1,2,2-tetrachloroethane, tetrachloroethylene, 1,1,1-trichloroethane, and trichloroethylene

MCS: $\mathrm{Al}, \mathrm{Cl}, \mathrm{Cr}, \mathrm{Co}, \mathrm{Cu}, \mathrm{F}, \mathrm{Mn}, \mathrm{Hg}, \mathrm{NO}_{3}, \mathrm{Na}, \mathrm{SO}_{4}, \mathrm{PO}_{4}, \mathrm{U}$, and $\mathrm{Zn}$

Radiologic

Parameters: Gross Alpha, nonvolatile beta, and radium (tot. alpha emitting)

This investigation was undertaken with the primary purpose of assessing the groundwater monitoring program within the A/M Area to identify ways in which the monitoring program could be streamlined and improved. The task was difficult due to the large number of wells located within the $\mathrm{A} / \mathrm{M}$ Area and a huge database of analytical data that has been collected. It was recognized early in this investigation that one of the key tasks was to develop a way to gain access to the groundwater databases so that recommendations could be made. To achieve this, GIS technology was used to extract pertinent groundwater quality information from the GIMS groundwater database and display the extracted information spatially. This technology was also used to determine the location of well screen and annular material zones within the $\mathrm{A} / \mathrm{M}$ Area hydrostratigraphy and to identify wells that may breach confining units.

Two master lists of wells were utilized in the investigation, one containing all wells in the $A / M$ Area, including special investigation wells, vadose zone wells and many other wells that are not routinely monitored. This list contains over 500 wells and is presented in Table $A$ in the Appendix. A second list was utilized for specific recommendations relating to sample collection. This list was formulated by Rust, Inc. as a task to Environmental Restoration Department (ER) and includes those wells currently in the groundwater sampling program. This list is presented in Table B in the Appendix. 


\subsection{ANALYSIS}

To identify ways in which the groundwater monitoring program might be improved, the focus of the analysis was on issues relating to whether individual wells are capable of providing groundwater samples that are representative of aquifer units within which they are finished. Factors which contribute to this ability include: the adequacy of well construction, the strategic location of the well within the groundwater flow system and the ability of the well to provide a sufficient quantity of water to provide representative groundwater samples.

While the great majority of wells installed at SRS since the early 1980's are perfectly adequate, samples collected at some wells suggests there may be a problem with the well construction that could impact their ability to provide representative groundwater samples.

Due to the number of wells in the A/M Area, this investigation relied heavily upon the use of database queries to extract pertinent information from the Environmental Monitoring Section (EMS) groundwater databases so that evaluations could be made. GIS tools were then used to evaluate the information extracted from GIMS, including well construction, field parameters and analytical data. The result was a series of tables of well information which could be used to assess the adequacy of wells for groundwater monitoring.

Well sample reliability relates to the ability of a well to provide a groundwater sample that is representative of groundwater quality in the aquifer unit within which it is screened. Factors which contribute to this ability include the adequacy of well construction and the ability of the well to produce a sufficient quantity of water to produce a sample truly reflective of the groundwater conditions in the vicinity of the well screen. Well construction factors include the position of the well screen and sand pack relative to hydrostratigrapic units, grout contamination of filter pack near the screen zone, and how effective the well development process was. The ability of a well to produce a sufficient quantity of qroundwater is related to whether the screen exists fully or partially within the saturated zone, the well development process, and the natural permeability of the formation material adjacent to the screen zone.

Some wells in the groundwater monitoring network may never experience elevated concentrations because their location within the groundwater flow system is such that they may never sample contaminated water. These wells are situated lateral to the primary horizontal flow direction or are located downgradient, at a relatively great distance from the source area, and finished in only the uppermost portion of the saturated zone. Other wells may be located sufficiently far from the source areas in the downgradient direction that they will detect only the most mobile contaminants in the foreseeable future, yet they are sampled at least annually for contaminants that are not mobile.

\subsection{Hydrogeologic model}

The hydrogeologic model utilized for comparison with well construction data is that incorporated in the $\mathrm{A} / \mathrm{M}$ Area general groundwater model by Jackson, Savannah River Technology Center/Environmental Sciences Section SRTC/ESS (personal communication). The specific layers include the following seven hydrostratigraphic units, listed from deepest to shallowest: Crouch Branch Aquifer; Lower Clay-Crouch Branch Confining Unit; Middle SandCrouch Branch Confining Unit; Upper Clay-Crouch Branch Confining Unit, Lost Lake Aquifer, Green Clay Confining Unit and the M-Area Aquifer Unit. The hydrostratigraphic picks 
embodied in this model have been deciphered from borehole cores and borehole geophysical logs. Table 2, below, lists the hydrostratigraphic units for A/M Area.

Table 2 Hydrostratigraphic Units in the A/M Area

\begin{tabular}{|l|l|}
\hline & HYDROSTRATIGRAPHIC UNIT \\
\hline Layer 1 & M-Area Aquifer \\
\hline Layer 2 & Green Clay Confining Unit \\
\hline Layer 3 & Lost Lake Aquifer \\
\hline Layer 4 & Upper Clay - Crouch Branch Confining Unit \\
\hline Layer 6 & Middle Sand - Crouch Branch Confining Unit \\
\hline Layer 6 & Lower Clay - Crouch Branch Confining Unit \\
\hline Layer 7 & Crouch Branch Aquifer \\
\hline
\end{tabular}

Elevations of the interfaces between hydrostratigriphic units were obtained as gridded EarthVision files. The EarthVision command EV_EXPORT was used to generate data files that could then be incorporated into ARC/INFO.

\subsection{Geographic Information Systems Analysis}

GIS analysis supporting the A/M Area well reduction study included two main objectives-determining the hydrostratigraphic units where the tops and bottoms of $\mathrm{A} / \mathrm{M}$ Area well screen and annular material zones are located and accessing GIMS to obtain and display analyte information for these wells. GIMS is an Oracle database maintained by EMS that houses groundwater geochemistry, well construction, and soils data for the Savannah River Site.

The first objective involved accessing the GIMS well construction database to obtain construction data for the 570 wells included in the study (See Table A of the Appendix for a listing of these wells). The GIMS well construction database contains information such as well use, well geographic coordinates, depth to the top and bottom of screen and annular materials zones, and annular materials descriptions. This information was accessed using Oracle Structured Query Language (SQL) embedded in ArcView Avenue scripts so that the data could be imported directly into ArcView for analysis and display. The resulting annular materials table was subsequently used to generate an ARC/NFO GIS coverage. Well screen zone data was already available as a GIS coverage on the Environmental Protection Department (EPD) ArcView system. Well locations for both the annular material and screen zone coverages are in SRS coordinates.

In order to determine the hydrostratigraphic units where the screen zones and annular material zones are located for each $\mathrm{A} / \mathrm{M}$ Area well, a hydrostratigraphic model was first required. This model consisted of the eight surfaces which bound the seven hydrostratigraphic layers identified above. These eight surfaces were defined as elevations at nodal points on a regularly spaced grid network. These surfaces were contoured by the SRTC/ESS using EarthVision software on a 500 $\mathrm{ft}$. grid mesh and were converted to ARC/NNFO grid coverages as part of this study.

The ARC/NNFO LATTICESPOT command was then used to determine the vertical elevation on all eight surfaces corresponding to the $\mathrm{x}, \mathrm{y}$ location of each well. This process may be visualized 
by placing a vertical line at each well $x, y$ location such that the line penetrates the surfaces directly underlying the given well. LATTICESPOT determines the vertical elevation where the vertical line intersects each surface and writes this elevation to the ARC/INFO coverage containing the well coordinates. A total of eight elevation attributes were added to the annular materials and screen zone ARC/INFO coverages (seven elevations for the seven hydrostratigraphic surfaces and one for the land surface).

The hydrostratigraphic unit containing the top and bottom of each well screen or annular material zone was determined using an ARC Macro Language (AML) routine written to compare the tops and bottoms of screen and annular material zone elevations with the corresponding elevations on all eight surfaces at each well $x, y$ coordinate. For each well, attributes were written to the screen zone coverage indicating the hydrostratigraphic unit name corresponding to the top and bottom screen elevation. Likewise, for the annular materials coverage, attributes indicating the hydrostratigraphic unit containing the top and bottom annular materials zones were written to the annular materials coverage. Tables $C$ and $D$ of the Appendix provide a partial listing of the resultant ARC/NNFO annular materials and screen zone coverage point attribute tables, respectively. A description of the attributes for the screen zone and annular materials ARC/INFO point attribute tables is provided in Tables $\mathrm{E}$ and $\mathrm{F}$ of the Appendix, respectively.

Well screen zones potentially breaching a confining unit were identified in the screen zone coverage by comparing the hydrostratigraphic unit containing the top and bottom screen location. A potential confining unit breach was identified if the top and bottom screen location hydrostratigraphic units were different. An additional field labeled 'breach' was written to the screen zone ARC/INFO coverage (see Table D of the Appendix) indicating the possibility of a breached confining unit.

The screen zone ARC/MNFO coverage contains one record per well whereas the annular materials coverage has up to three records per well, depending on the number of distinct annular material zones. The annular materials data thus presented a complication in determining whether confining units are potentially breached. Annular materials zones which are continuous without breaks and which consist of porous materials such as sand, fine sand, or gravel may not penetrate a confining unit when considered as separate and distinct zones. The same annular materials considered as a continuous zone, however, may very well extend across a confining unit.

An additional AML was therefore written to determine whether the porous annular materials for a given well are continuous and whether the continuous zone penetrates a confining unit. This AML utilized as input the annular materials coverage described above (see Table $C$ of the Appendix). Table $C$ provides a partial list of records from the annular materials coverage where continuous annular materials zones have been combined, using the AML described above, to form a single record in the table.

Note that only wells with one or two annular materials zones were considered due to apparent inconsistencies in the well construction data. Out of 242 wells processed for the A/M Area, this constraint excluded only 29 wells. Finally, note that well construction data for $150 \mathrm{~A} / \mathrm{M}$ Area wells in this study was not in the well construction database.

The second major objective involved accessing the groundwater geochemistry data in GIMS for the analytes listed on Table $G$ of the Appendix. The A/M Area wells listed in Table B of the Appendix were used in conjuntion with GIMS queries so that data for only these wells was 
retrieved. Queries of the GIMS Oracle database on Pleiades were made using SQL embedded in Avenue scripts so that the data could be pulled directly into ArcView tables. These tables were then processed using the ArcView query builder to include only records with flag 1 contaminant levels. Flag 1 corresponds to one half of the Environmental Protection Agency (EPA) drinking water standard. The flag 1 concentration limit is provided for the analytes of interest in Table $G$ of the Appendix.

Note that the GIMS analyte data contains analyte sample result units in both milligrams per liter and micrograms per liter so that care had to be exercised in building the ArcView queries to use flag 1 search criteria compatible with the two different measurement units. Analyte data was pulled from GIMS for the wells listed in Table B of the Appendix for all periods of record and includes split samples, replicates, blind samples, duplicates, etc. This analyte data also included flag 1 hits below the detection limit, estimated analyte results, and rejected results. Obviously, significant care must be exercised by the user of this data to make sure inappropriate data are not used in analyses. GIMS groundwater geochemistry data on Pleiades is available from the first quarter of 1991 through the fourth quarter of 1995.

Several of the analyte tables were processed further to remove duplicate, replicate, split and other duplicate records so that the analyte information could be displayed spatially in ArcView. These tables were edited and duplicate records were removed arbitrarily. The edited tables include flag 1 hits for trichloroethylene (TCE) during the fourth quarter of 1994, mercury (first quarter of 1995), nitrate (first quarter of 1995), and tetrachloroethylene (PCE) during the third quarter of 1995 and were generated to examine the spatial distribution of the respective flag 1 contaminant hits. Data in these tables should be used only for inferring the spatial coverage of flag 1 hits and not for the determination of the specific analyte concentrations at any given well. In addition, any GIMS geochemical data included in this report and the aforementioned ArcView project must be screened by EMS personnel prior to release or use.

Wells exhibiting TCE and PCE concentrations equal to or in excess of the flag 1 criteria for the M-Area aquifer are provided in Figures 1 and 2, respectively, and for the Lost Lake aquifer in Figures 3 and 4, respectively. Data presented in these figures should be used only for inferring the spatial distribution of flag 1 hits and should not be used for any other purpose.

\subsection{Evaluation}

Information obtained from the database queries and GIS processing was utilized to perform evaluations and address the issue of well integrity. Factors which might be indicative of the lack of well integrity would include: sample analyses from individual wells which are chronically elevated in $\mathrm{pH}$ and turbidity, inability of a well to provide sufficient quantity of water to obtain a sample, and well screens and sand packs which are found to breach confining units that separate different aquifers. The evaluation also included an assessment of the strategic position of certain wells with respect to their ability to detect potential contaminants in the groundwater flow system. 
Figure 1. TCE Concentration in Wells Finished in the M-Area Aquifer
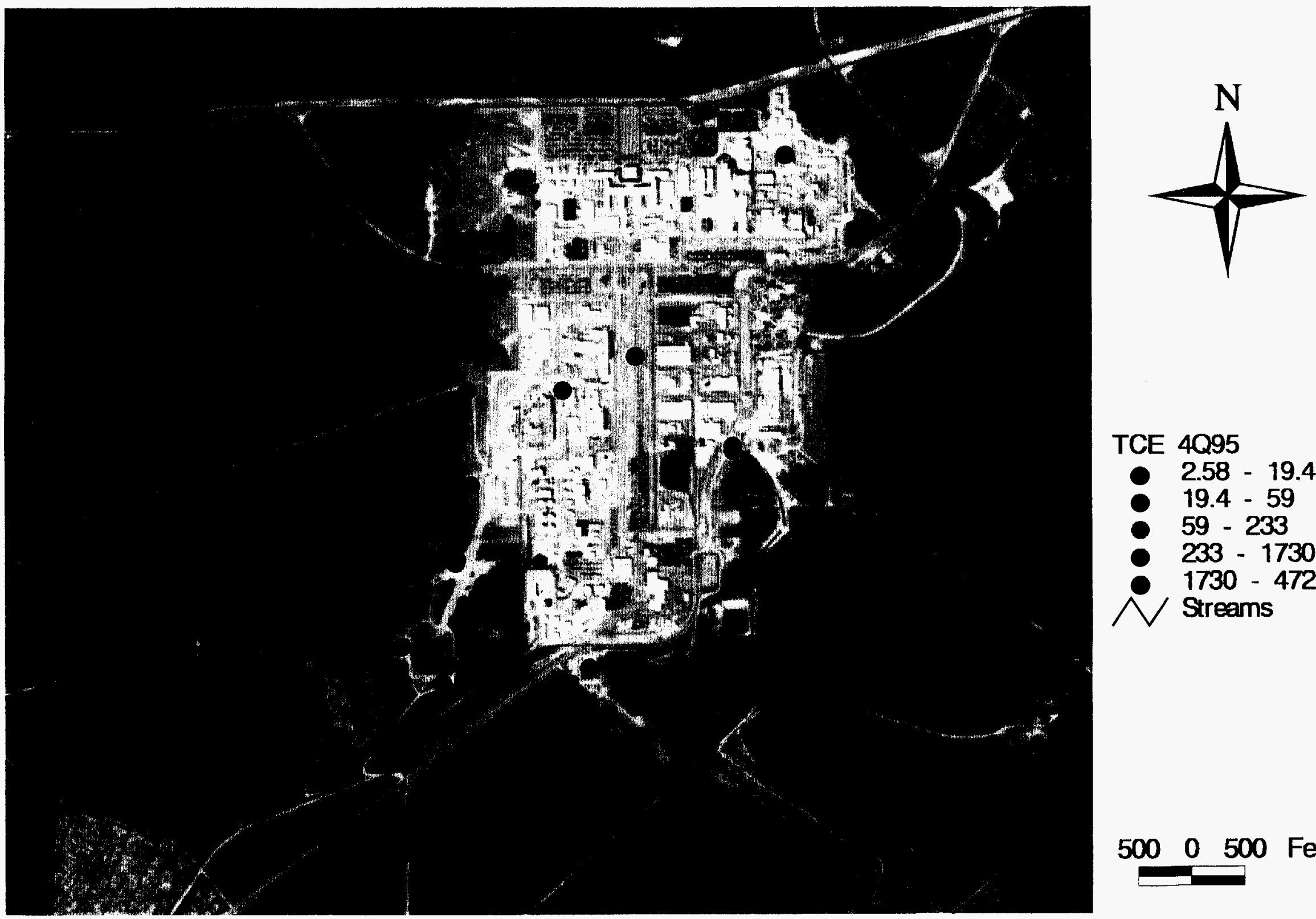

TCE 4095

- $2.58-19.4$

- $19.4-59$

- $59-233$

- $233-1730$

- $1730-47200$

$\curvearrowright$ Streams

$\begin{array}{llll}500 \quad 0 \quad 500 & \text { Feet }\end{array}$ 
Figure 2. PCE Concentration in Wells Finished in the M-Area Aquifer

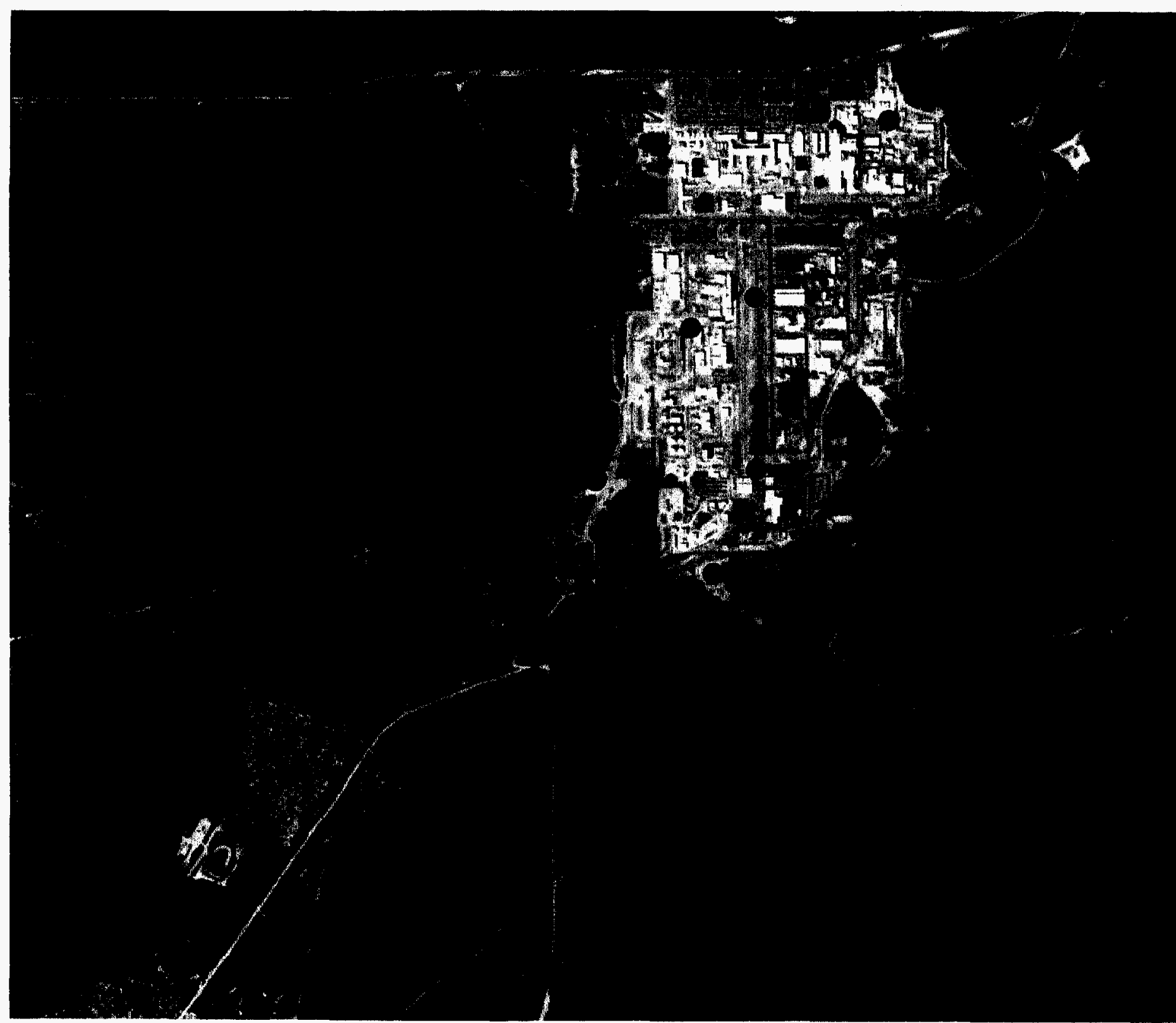

PCE 3q95

- $3.17-10$

- $10-28.8$

- $28.8-79$

- $79-400$

- $400-64800$ 
Figure 3. TCE Concentration in Wells Finished in the Lost Lake Aquifer

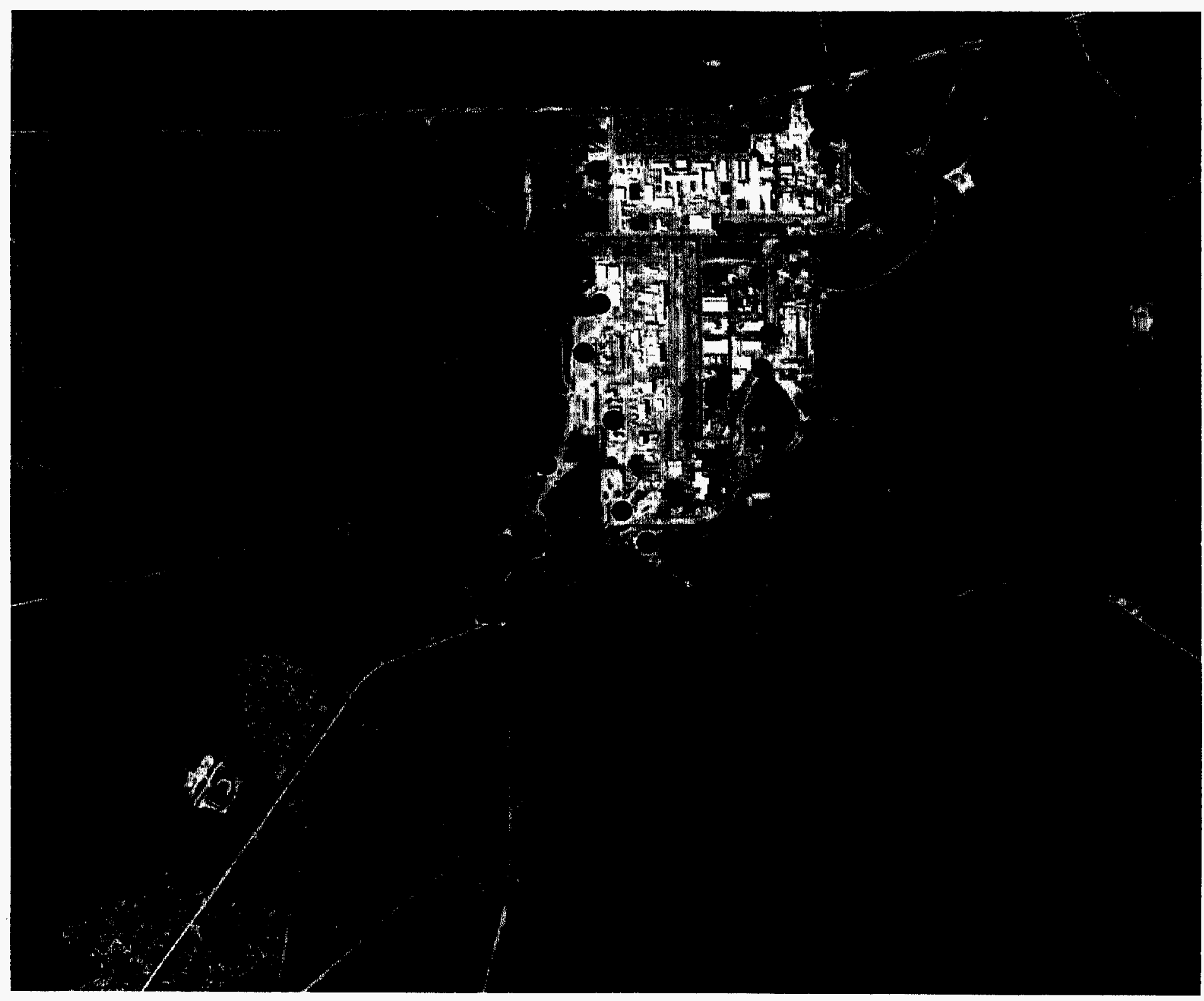

TCE 4095

- $2.58-19.4$

$19.4-59$

$59-233$

$233-1730$

- $1730-47200$

5000500 Feet 
$\frac{1}{3}$

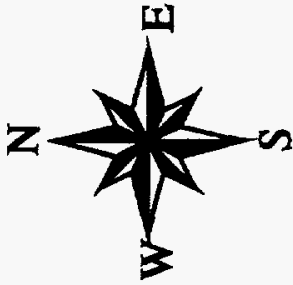

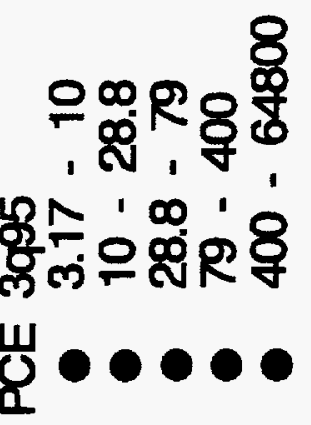

\$

난

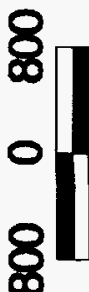

$\frac{9}{1}$

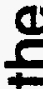

E

7

E

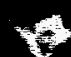

T.

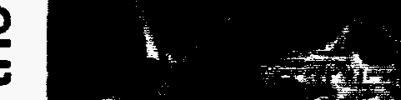

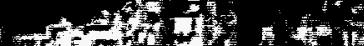

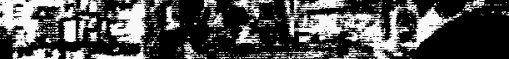

y $=0,2, z$

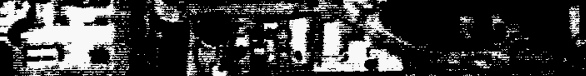

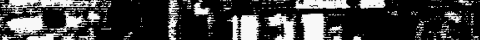

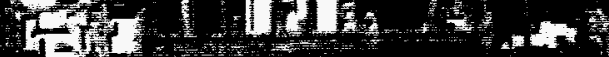

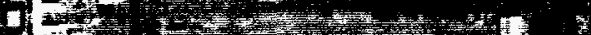

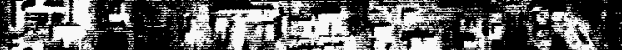

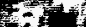

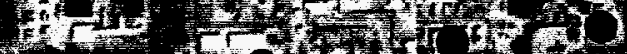

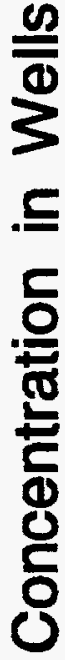

U

()

a.

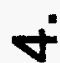

(1)

5

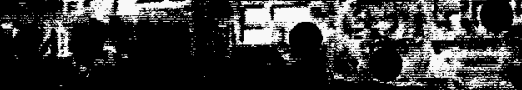




\subsubsection{Well integrity and sample reliability}

An SQL query of the GIMS database was used to extract sample analyses from wells for $\mathrm{pH}$, turbidity and whether the well pumped dry during the period from 1992 to present. During 1992 a new policy was implemented that required that samples collected from wells no longer be filtered prior to performing any laboratory analyses. Prior to this all samples were filtered before analysis. The query was restricted to that period when samples were no longer filtered in order to avoid comparing results from filtered samples with non-filtered samples. ArcView was used to display anomalous wells and to create tables. The criteria for determination of anomalous values were $\mathrm{pH}<4.0$ or $\mathrm{pH}>8.5$ and turbidity $>20 \mathrm{ntu}$ (nominal turbidity units). Consideration was only given to elevated values of $\mathrm{pH}$ since the grout material used in well construction is very alkaline. Low values of $\mathrm{pH}$, on the other hand, may be indicative of contaminants the well was installed to monitor. Wells with chronic $\mathrm{pH}$ values $>8.5$ could indicate problems that relate to the grout emplacement at the time of well installation. The altered $\mathrm{pH}$ can have the effect of biasing the concentrations of any potential contaminants in groundwater samples from that well. Listed below in Table 3 are wells in the A/M Area which exhibit chronically elevated $\mathrm{pH}$ levels. Also noted is the number of quarters since the beginning of 1992 that elevated values were detected and the mean value obtained in all anomalous measurements.

Table $3 \quad$ Wells having elevated pH sample analyses

\begin{tabular}{|l|c|c|c|}
\hline Well & $\begin{array}{l}\text { No. Quarters } \\
\text { 92-'96 }\end{array}$ & $\begin{array}{l}\text { Average } \\
\text { pH Value }\end{array}$ & $\begin{array}{l}\text { Well } \\
\text { Type }\end{array}$ \\
\hline & & & \\
\hline AMB-10A & 16 & 11.1 & PDW \\
\hline AMB-13AR & 13 & 10.8 & PDW \\
\hline AMB-6AA & 16 & 10.8 & PDW \\
\hline ASB-6TA & 18 & 10.8 & PDW \\
\hline MCB-5C & 20 & 12 & PDW \\
\hline MCB-7C & 16 & 12.2 & PDW \\
\hline MSB-13B & 20 & 11.9 & PDW \\
\hline MSB-1C & 24 & 11.7 & POC \\
\hline MSB-20C & 16 & 10.9 & PDW \\
\hline MSB-2B & 20 & 11.9 & POC \\
\hline MSB-2C & 22 & 11.3 & POC \\
\hline MSB-3C & 18 & 11.9 & POC \\
\hline MSB-46A & 16 & 9.2 & PDW \\
\hline MSB-48D & 13 & 9 & PDW \\
\hline MSB-4C & 15 & 10.7 & POC \\
\hline MSB-54C & 15 & 10.6 & PDW \\
\hline MSB-55HC & 18 & 11.5 & PDW \\
\hline MSB-62D & 23 & 11.7 & POC \\
\hline MSB-63D & 22 & 9.9 & POC \\
\hline MSB-66B & 17 & 10.3 & PDW \\
\hline MSB-6C & 15 & 10.8 & POC \\
\hline MSB-71B & 16 & 11.9 & PDW \\
\hline MSB-74C & 17 & 11.2 & PDW \\
\hline MSB-79B & 17 & 12.3 & PDW \\
\hline MSB-79C & 15 & 11.9 & PDW \\
\hline MSB-7B & 21 & 10.9 & POC \\
\hline MSB-82A & 23 & 11.8 & PDW \\
\hline MSB-83C & 17 & 9.3 & PDW \\
\hline MSB-83D & 11 & 8.9 & PDW \\
\hline MSB-85TA & 17 & 9 & PDW \\
\hline
\end{tabular}


Elevated levels of turbidity, $>20 \mathrm{ntu}$, may indicate that the well was incompletely developed or that the screen zone is finished in a low permeability formation. This is an informal threshold used by EMS personnel who maintain the GIMS database. Since well samples are no longer filtered prior to conducting the analyses, elements that comprise clay minerals may appear in elevated concentrations in analyses. Likewise, any other cations which might be adsorbed to the clay particles will also appear in elevated concentrations. Table 4 contains a list of all wells in the A/M Area which exhibited turbidity levels $>20$ ntu during the period of 1992 to the present. The number times the turbidity was elevated and the average turbidity level is also reported.

- Table $4 \quad$ Wells having elevated turbidity in samples

\begin{tabular}{|l|c|c|c|}
\hline Well & $\begin{array}{l}\text { Number of } \\
\text { elevated } \\
\text { samples 92-96 }\end{array}$ & $\begin{array}{l}\text { Average } \\
\text { NTU } \\
\text { Value }\end{array}$ & $\begin{array}{l}\text { Well } \\
\text { Type }\end{array}$ \\
\hline & 6 & 59 & PDW \\
\hline AMB-5 & 10 & 456 & PDW \\
\hline MCB-5C & 5 & 137 & PDW \\
\hline MCB-7C & 8 & 210 & PDW \\
\hline MSB-15C & 10 & 471 & PDW \\
\hline MSB-16C & 11 & 238 & PDW \\
\hline MSB-36D & 5 & 573 & POC \\
\hline MSB-3D & 7 & 319 & PDW \\
\hline MSB-42D & 10 & 240 & PDW \\
\hline MSB-46C & 6 & 46 & PDW \\
\hline MSB-48D & 6 & 34 & POC \\
\hline MSB-57D & 6 & 26 & POC \\
\hline MSB-60D & 7 & 27 & PDW \\
\hline MSB-70D & 9 & 50 & PDW \\
\hline MSB-85TA & 10 & 131 & PDW \\
\hline MSB-86C & 5 & 445 & PDW \\
\hline SRW-16A & & & \\
\hline
\end{tabular}

Another indicator of whether a well is capable of providing a representative sample is its ability (or inability) to produce water at a sufficient rate to collect a sample. Such wells may be finished in low permeability formations, or could have been incompletely developed. A list of wells which are in the groundwater monitoring program and for which sample collection personnel have had difficulty obtaining water in sufficient quantity to collect a a sample are listed below in Table 5. Typically, sample collection personnel purge these wells, then return at a later time to collect the samples. Only the wells that had to be revisited at least $20 \%$ of the time are listed in Table 5. 
Table 5.

Wells with a history of pumping dry (1988-1996)

\begin{tabular}{|l|l|l|l|l|l|l|}
\hline Well Name & $\begin{array}{l}\text { No. of } \\
\text { Sample } \\
\text { events } \\
\text { from 88-96 }\end{array}$ & $\begin{array}{l}\text { No. of } \\
\text { times no } \\
\text { sample }\end{array}$ & $\begin{array}{l}\text { No. of } \\
\text { samples - } \\
\text { wait for } \\
\text { recovery }\end{array}$ & $\begin{array}{l}\text { \% of times } \\
\text { no sample }\end{array}$ & $\begin{array}{l}\% \text { of times } \\
\text { wait for } \\
\text { recovery }\end{array}$ & Well Type \\
\hline AMB-10A & 34 & 0 & 11 & 0 & 32 & PDW \\
\hline AMB-13AR & 33 & 0 & 10 & 0 & 30 & PDW \\
\hline AMB-14D & 9 & 0 & 2 & 0 & 22 & PDW \\
\hline AMB-15D & 10 & 0 & 4 & 0 & 40 & PDW \\
\hline MSB-1C & 45 & 0 & 13 & 0 & 29 & POC \\
\hline MSB-1CC & 38 & 0 & 10 & 0 & 26 & POC \\
\hline MSB-2B & 40 & 0 & 10 & 0 & 25 & POC \\
\hline MSB-2C & 42 & 0 & 12 & 0 & 29 & POC \\
\hline MSB-4C & 39 & 0 & 10 & 0 & 26 & POC \\
\hline MSB-5C & 40 & 0 & 10 & 0 & 25 & POC \\
\hline MSB-6C & 43 & 0 & 12 & 0 & 28 & POC \\
\hline MSB-7B & 46 & 0 & 13 & 0 & 28 & POC \\
\hline MSB-13CC & 45 & 0 & 12 & 0 & 27 & POC \\
\hline MSB-13D & 43 & 0 & 12 & 0 & 28 & POC \\
\hline MSB-55HC & 44 & 0 & 11 & 0 & 25 & PDW \\
\hline MSB-59D & 39 & 0 & 10 & 0 & 26 & POC \\
\hline MSB-60D & 40 & 0 & 10 & 0 & 25 & POC \\
\hline MSB-62D & 44 & 0 & 12 & 0 & 27 & POC \\
\hline MSB-63D & 42 & 0 & 11 & 0 & 26 & POC \\
\hline MSB-82A & 47 & 2 & 15 & 4.3 & 32 & PDW \\
\hline MSB-83D & 38 & 0 & 10 & 0 & 26 & PDW \\
\hline MSB-85TA & 46 & 0 & 13 & 0 & 28 & PDW \\
\hline MSB-87C & 17 & 0 & 5 & 0 & 29 & PDW \\
\hline
\end{tabular}

A few wells in the A/M Area may have screens installed in positions that straddle confining units. Since sand packs are routinely emplaced in the well annular space surrounding the well screen, the effective screen zone is actually the zone for which a permeable filter pack material has been emplaced. Normally this extends from a few feet below the screen zone to several feet above the screen zone. If filter pack zones extend across confining units, samples collected from that well will reflect groundwater chemistry in both aquifers. Furthermore, the well may act as a vertical conduit for migration of groundwater from one aquifer to another and water levels recorded in the well will not be reflective of the potentiometric level in either aquifer.

A query was formulated to extract information from the well construction and annular materials databases. An Arc/Info AML was developed to compare these elevations to the hydrostratigraphic elevations at the location for each well. Subsequent processing with GIS was initiated to create tables of wells in the A/M Areas which apparently breach confining units. It should be noted that the well annular material database is still in the developmental stage and that not all wells at SRS are included in the database at this time. Also, during the process of extracting information from the database it became apparent that there are still problems with some of the data in the database. EMS is currently working to resolve these problems. Finally, this analysis ignored well annular materials where there were three or more permeable materials in the well annulus. The great majority of wells have either one or two different permeable materials surrounding the screen zone, however it is likely that a few wells with more than two materials were not identified in this investigation. 
Tables $C$ and $D$ in the Appendix provides well information relating to well annular material and screen zone elevations for a partial list of wells in the A/M Area. The information was used to determine if either the annular material or screen zone of each well extended entirely across (or breached) either the Green Clay Confining Unit or the Upper Clay of the Crouch Branch Confining Unit. This information is presented with the caveat that the determination of a "breach" is dependent not only upon the accuracy of the data contained in the well construction and well annular material databases, but also on the accuracy of the hydrogeologic model used in the study. Wells that apparently breach a confining unit and are in the groundwater monitoring program are listed below in Table 6.

Table $6 \quad$ Wells that apparently breach a confining unit

\begin{tabular}{|l|c|c|}
\hline WELL & $\begin{array}{l}\text { CONFINING UNIT } \\
\text { APPARENTLY } \\
\text { BREACHED }\end{array}$ & WELL TYPE \\
\hline & & \\
\hline ABP-8C & GC & PZ \\
\hline ABW-1 & GC & PZ \\
\hline AMB-12D & GC & PDW \\
\hline AMB-4D & GC & PDW \\
\hline ARP-2 & GC & PZ \\
\hline ASB-8A & UCCRBRCU & PZ \\
\hline MSB-29D & GC & PGW \\
\hline MSB-30B & UCCRBRCU & PZ \\
\hline MSB-35A & UCCRBRCU & PDW \\
\hline MSB-39C & GC & PZ \\
\hline MSB-40D & GC & PDW \\
\hline MSB-45A & UCCRBRCU & POC \\
\hline MSB-5C & GC & PDW \\
\hline MSB-69D & GC & PDW \\
\hline MSB-77B & UCCRBRCU & PDW \\
\hline MSB-82D & GC & PDW \\
\hline MSB-83D & GC & PZ \\
\hline SRW-3A & GC & \\
\hline
\end{tabular}

Note: GC - Green Clay; UCCRBRCU - Upper Clay of the Crouch Branch Confining Unit PZ - Piezometer, PDW - Plume Definition Well, BGW - Background Well POC - Point of Compliance Well

\subsubsection{Strategic location}

The specific location of a well and its distance from the source area is vital to its ability to detect any contaminants that might be emanating from a disposal facility in the subsurface. Wells should be located in the down gradient direction, in both the horizontal and vertical directions in order to intercept and sample water that is moving along the groundwater flow paths that originate at the disposal facility that is being monitored. In particular, certain wells that are located at some distance may never intercept any contaminants because they only penetrate a few feet into the saturated zone and monitor relatively clean water originating as recharge.

Differences in individual contaminant solubility and ionic charges result in some contaminants being more mobile than others. Positively charged elements or molecules tend to adsorb to the 
surfaces of clay minerals in the subsurface thus retarding their movement. For those wells located at a relatively great distance from the source area, there is little chance of detecting the relatively immobile contaminants. Analyses for these contaminants are often conducted routinely on samples collected from relatively distant wells, some of which penetrate only the top few feet of the water table aquifer.

To address the issue of strategic location for wells that are currently a part of the groundwater monitoring network the following approach was utilized. A map of the A/M Area having all of the monitoring wells finished in the M-Area Aquifer posted, along with TCE concentrations at each well, was examined. The approximate boundary of the TCE plume was noted with respect to the location of certain wells. A group of wells outside the plume extent was selected and a determination made if a water table well existed at that location. Next, these wells were evaluated in terms of average TCE concentration and for any flag 1 violations since 1992. The wells that were located at a relatively great distance from the source area and are finished in the shallowest part of the aquifer are listed below in Table 7 .

Table 7. Wells that are not optimally located to detect possible contaminants

\begin{tabular}{|l|c|}
\hline WELL & WELL TYPE \\
\hline & \\
\hline MSB-87C & PDW \\
\hline MSB-48D & PDW \\
\hline MSB-54D & PDW \\
\hline MSB-55D & PDW \\
\hline MSB-49D & PDW \\
\hline MSB-70D & PDW \\
\hline MSB-32C & PDW \\
\hline
\end{tabular}

Note: PDW- Plume Definition Well 


\subsection{RECOMMENDATIONS}

The analyses undertaken in this investigation were directed toward identification of wells which might fall into the following categories: wells that may not be providing reliable data but continue to be routinely sampled and wells that may be inappropriately located but continue to be routinely sampled. Specific recommendations are provided with this in mind while other recommendations identify further work that should be undertaken, including GIS development and detailed evaluation of wells that may be breaching confining units.

\subsection{Recommendations relating to well integrity}

- Elevated $\mathrm{pH}$ and turbidity recommendations

Sixteen wells were identified in the analysis part of this report as repeatedly having elevated turbidity measurements. The range of average values from each well was from 26 to 573 . EMS regards any value of ntu $>20$ to be elevated. All of the wells are either PDW or POC wells and are actively monitored as part of the groundwater monitoring program in $\mathrm{A} / \mathrm{M}$ Area according to the schedule identified in Table 1 in the text. The most likely cause for the elevated turbidity is incomplete development. All of these wells would probably benefit from additional well development but the wells with the highest turbidity would benefit the most. The use of a dispersing agent in the development process has been shown to significantly enhance the removal of clay material from the filter pack and formation material and would be of great benefit if re-development is conducted on these wells. A combination of established methods and newly available methods could be employed.

The database screening identified 30 wells in the $\mathrm{A} / \mathrm{M}$ Area, all of which are actively monitored, as having chronically elevated $\mathrm{pH}$ values. The most likely cause is improper grout emplacement or curing. A proven methodology for remediating wells having grout contamination in the vicinity of the filter pack is not available. Since four wells having elevated $\mathrm{pH}$ (MSB-5C, $-7 \mathrm{C}$, $48 \mathrm{C}$, and $-85 \mathrm{TA}$ ) also have elevated turbidity, these wells could be monitored to see if additional development work has any impact alleviating their $\mathrm{pH}$ problem.

\section{- Screen zone analysis recommendations}

The 18 wells listed in Table 6 . have permeable annular materials that apparently breach confining units adjacent to those zones. More work is required to determine if this is actually the case. It is likely that some of these wells are finished at locations where the Green Clay confining unit and the Upper Clay of the Crouch Branch Confining Unit do not exist in the subsurface. Since the hydrogeologic model originated as layer coverage in a groundwater flow model, all layers have to be continuous across the domain. In areas where confining units pinch out hydraulic characteristics of aquifer are assigned to the layer. This may give a false hit on the screening that was done to identify wells that breach confining unit. It is recommended that careful follow up work be conducted to evaluate each well to determine if the sand pack does actually breach the confining unit. The detailed work should involve inspection of the borehole geophysical logs from each of the wells (or from the nearest cluster well neighbor having borehole geophysical logs) and examination of the well construction records. 
Seven of the wells are not a part of the groundwater monitoring program for the $\mathrm{A} / \mathrm{M}$ Area and therefore are not a concern in regard to acquisition of representative samples. However, these wells may be acting as conduits for vertical migration of water between aquifers and some estimate of this impact will still be needed if they are eventually found to actually breach confining units. If any of the other 11 wells are confirmed as breaching a confining unit careful consideration must be given to whether they should remain on the sample schedule.

\subsection{Recommendations relating to well location}

Table 7 identifies 7 wells as being situated at a location where they are not likely to monitor any contaminants in the subsurface, only 5 are wells that are actually monitored in the groundwater monitoring program. These wells are MSB-87C, $-48 \mathrm{D},-54 \mathrm{D},-55 \mathrm{D},-49 \mathrm{D}-70 \mathrm{D}$, and $-32 \mathrm{C}$. These wells all penetrate the upper part of the saturated zone and do not have elevated TCE analyses. Locally introduced recharge at the water table is thought to cause these wells to intercept clean water, whereas natural flow paths originating at the disposal facilities are thought to carry dissolved contaminants deeper into the groundwater flow system. Deeper wells located at the same clusters, however, may intercept any dissolved contaminants. It is recommended that these wells be considered for dropping the MCS analytes that are analyzed for during the third quarter every year. These analytes are relatively immobile and are not likely to have migrated far from the source areas. It is also recommended that some consideration be given to eliminating the GPWS analyses that are done or, at a minimum, reduce them to a once per year event. Currently, GPWS analyses are conducted twice, annually. If GPWS analyses are not eliminated, the sample suite should be reduced to eliminating the non-organic analytes of that suite.

Another recently completed study, conducted under the direction of Lynn Ehrke, ER, has concluded that extensive modifications to the sample schedule of PDW wells should be made. The recommendation from that study is to analyze samples from those wells only for TCE and PCE and to eliminate the analyses for other GWPS and MCS analytes. That conclusion is supported by this investigation, although the recommendation is made for all PDW wells and not simply the remotely located PDW wells. Many PDW wells experience elevated levels of TCE/PCE but not for other contaminants. Despite this pattern, the wells are repeatedly sampled and analyzed for the MCS and GPWS analyte suites, most of which are relatively immobile species and have never been detected at locations away from the disposal sites.

\subsection{Recommendations for further GIS development}

GIS is a very powerful tool for accessing data in relational databases such as Oracle, displaying the data, and performing complex analyses. In this study, SQL was used to retrieve GIMS data and bring the data directly into ArcView for display and analysis. Constructing the SQL strings to obtain the desired GIMS data required considerable time and could be greatly simplified to allow individuals not familiar with SQL to query the GIMS geochemical database and obtain data for their own GIS analyses using ArcView.

ArcView access to GIMS could be automated to allow users to select GIMS data by well name, quarter, analyte, or geographic location using a menu driven graphical user interface. ArcView could then be used to analyze the data to geographically locate wells exceeding specified analyte concentrations, etc. 
ArcView is a Windows based desktop GIS application that is quite easy to use and can be loaded onto any Macintosh or IBM compatible PC. ArcView can be used to display GIMS data on maps with user selected features such as roads, streams, buildings, soil type, aerial photos, etc. and can also be used to perform analyses of the GIMS data. This analysis capability includes making contaminant contour maps, trend plots of analyte and field data results over time, selecting wells according to user defined criteria (e.g. selecting all wells in the M-Area aquifer exceeding flag 1 concentrations for TCE and PCE for the fourth quarter of 1994), as well as many other powerful functions.

Automating an ArcView linking capability to GIMS would provide environmental scientist and engineers with a very powerful display and analysis tool. It is recommended that funding be allocated to provide this automated link in FY97. 


\subsection{REFERENCES}

Gordon, D.E., Johnson, W.F., Kaback, D.S., Looney, B.B, Nichols, R.L., Shedrow, C.B., 1987, Characterization Recommendations for Waste Sites at the Savannah River Plant, DPST-87-667, E.I. du Pont de Nemours \& Co. Savannah River Laboratory, Aiken, SC. 
WSRC-TR-96-0324

5.0 APPENDIX 
Table A. Master list of wells in the A/M Area 


\begin{tabular}{|c|c|c|c|c|c|c|c|c|c|c|c|c|c|c|c|c|}
\hline \multicolumn{2}{|c|}{$\overline{\text { TABLE A }}$} & & \multicolumn{5}{|c|}{ MASTER LIST OF WELLS IN A/M AREA } & & & & & & & & & \\
\hline WELL & TYPE & SRS N & SRS E & UTMN & UTME & $\mathrm{SZT}$ & SZ B & GRND & TOC & TOS & EWD & C DIA & CASING & PUMP & INSTALL & ABANDON \\
\hline$A \overline{A B P} \quad 1 \mathrm{~A}$ & $M w, \overline{P l}$ & 97501.6 & 44425.6 & 3686136.21 & 431186.55 & 202.9 & 172.9 & 357.9 & 359.9 & 360 & 187 & 4 & PVC & s & $8 / 15 / 84$ & \\
\hline ABP $1 D D$ & $\mathrm{Pz}$ & 97511.4 & 44433.6 & 3686139.53 & 431187.5 & 227.2 & 207.2 & 357.9 & 360.1 & & 152.9 & 2 & PVC & & $6 / 30 / 89$ & \\
\hline$\overline{A B P} 2 A$ & $\overline{M W}, \overline{P I}$ & 97764.3 & 44118.8 & 3686145.94 & 431064.67 & 211.1 & 181.1 & 370.1 & 371.9 & 372 & 190.8 & 4 & PVC & s & $8 / 10 / 84$ & \\
\hline ABP $2 D D$ & $\mathrm{Pz}$ & 97753.7 & 44126.7 & 3686144.81 & 431068.38 & 222.3 & 202.2 & 368.3 & 370.6 & & 168.4 & 2 & PVC & & $6 / 23 / 89$ & \\
\hline$\overline{A B P} 3$ & $\overline{M w}, \mathrm{PI}$ & 97794.1 & 44509.3 & 3686222.91 & 431155.51 & 236.9 & 206.9 & 351.9 & 353.7 & 353.8 & 146.8 & 4 & PVC & s & $8 / 4 / 83$ & \\
\hline$\overline{A B P} 3 \mathrm{C}$ & $\overline{\mathrm{Mw}}, \mathrm{PI}$ & 97778.2 & 44506.3 & 3686218.46 & 431157.34 & 165.3 & 160.3 & 352.3 & 354.5 & 354.8 & 194.2 & 4 & PVC & 5 & $7 / 10 / 89$ & \\
\hline ABP 4 & $\overline{M w}, \overline{P I}$ & 97489.7 & 44096 & 3686073.57 & 431107.91 & 212.5 & 182.5 & 362.5 & 364.3 & 364.5 & 181.8 & 4 & PVC & s & $6 / 21 / 84$ & \\
\hline ABP $4 D D$ & $\mathrm{Pz}$ & 97495.5 & 44101.3 & 3686075.79 & 431107.92 & 223.2 & 203.2 & 362.7 & 365 & & 161.8 & 2 & PVC & & $6 / 23 / 89$ & \\
\hline ABP $6 D$ & $\mathrm{Pz}$ & 97889.7 & 44101.4 & 3686172.74 & 431037.86 & 222.4 & 202.4 & 363 & 365.3 & & 162.9 & 2 & PVC & & $7 / 5 / 89$ & \\
\hline ABP 7D & $\mathrm{Pz}$ & 97449.7 & 43930.1 & 3686033.9 & 431074.11 & 225.2 & 205.2 & 361.9 & 364.2 & & 159 & 2 & PVC & & $6 / 30 / 89$ & \\
\hline$A B P B C$ & $\mathrm{Mw}, \mathrm{PI}$ & 97855.6 & 43968.7 & 3686140.79 & 431010.63 & 190.6 & 185.5 & 369.8 & 372.1 & 372.3 & 186.6 & 4 & PVC & s & $7 / 20 / 89$ & \\
\hline$\overline{A B P} 8 D$ & $M w, P I$ & 97854.9 & 43984.1 & 3686144.08 & 431014.38 & 228.2 & 208.1 & 368.8 & 370.9 & 371.1 & 162.8 & 4 & PVC. & s & $7 / 20 / 89$ & \\
\hline ABW 1 & $\mathrm{Mw}, \mathrm{Pl}$ & 105939.9 & 55016.4 & 3690114.34 & 432283.03 & 215.1 & 185.1 & 323.1 & 324.8 & 325 & 139.7 & 4 & PVC & s & $6 / 2 / 83$ & \\
\hline$\overline{A C} \quad 1 A$ & $M w, P \mid$ & 105865 & 42238.8 & 3687803.97 & 429148.8 & 145.7 & 140.7 & 260.7 & 262.1 & 262.4 & 121.4 & 4 & Steel & $s$ & $8 / 3 / 81$ & \\
\hline $\begin{array}{ll}A C & 1 B\end{array}$ & Mw,PI & 105862.8 & 42250.5 & 3687805.06 & 429151.6 & 202.1 & 197.1 & 261.1 & 262 & 262.2 & 64.9 & 4 & Steel & 5 & $7 / 28 / 81$ & \\
\hline$A C \quad 2 A$ & $\mathrm{Mw}, \mathrm{PI}$ & 105636.4 & 46428.6 & 3688499.13 & 430221.4 & 146 & 141 & 342.7 & 344.7 & 344.9 & 203.7 & 4 & PVC & s & 9/9/81 & \\
\hline 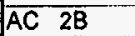 & Mw,PI & 105648.7 & 46444.5 & 3688504.66 & 430223.3 & 236.4 & 216.4 & 342.8 & 344.8 & 345 & 128.4 & 4 & PVC & s & $8 / 12 / 81$ & \\
\hline $\begin{array}{ll}A C & 3 A \\
\end{array}$ & $M w, P I$ & 100989.1 & 42119.8 & 3686581.57 & 429993.51 & 153.6 & 148.6 & 300.4 & 302.3 & 302.5 & 153.7 & 4 & PVC & s & $9 / 15 / 81$ & \\
\hline$A C \quad 3 B$ & Mw,PI & 100996.5 & 42113.6 & 3686582.7 & 429990.72 & 213.4 & 193.4 & 300.1 & 302.5 & 302.8 & 109.1 & 4 & PVC & S & $8 / 21 / 81$ & \\
\hline $\begin{array}{lll}A C B & 1 A\end{array}$ & $M w, \overline{P I}$ & 102622.9 & 51369.9 & 3688642.97 & 431979.59 & 247.6 & 217.6 & 357.6 & 359.6 & 359.7 & 142 & 4 & PVC & s & $1 / 11 / 84$ & \\
\hline$\overline{A C B} 2 A$ & $M w, P I$ & 102367.4 & 51561.3 & 3688614.6 & 432072.46 & 237.8 & 207.8 & 347.8 & 349.8 & 350 & 142 & 4 & PVC & s & $1 / 30 / 84$ & \\
\hline$A C B 3 A$ & $\mathrm{Mw}, \mathrm{Pl}$ & 102154.3 & 51313.3 & 3688517.2 & 432049.44 & 236.3 & 206.3 & 346.3 & 348.3 & 349.5 & 142 & 4 & PVC & s & $1 / 25 / 84$ & \\
\hline$\overline{\mathrm{ACB}} \overline{4 A}$ & $M w, \overline{P I}$ & 102343.9 & 51116.2 & 3688528.87 & 431966.69 & 241.7 & 211.7 & 356.7 & 359.1 & & 147.4 & 4 & PVC & s & $2 / 2 / 84$ & \\
\hline AMB $4 A$ & Mw,PI & 104131.6 & 51469.8 & 3689032.75 & 431733.83 & 126.3 & 121.3 & 378.3 & 380.5 & 380.7 & 259.2 & 4 & $\overline{P V C}$ & $s$ & $8 / 30 / 91$ & \\
\hline AMB 4B & $\bar{M} w, \overline{P I}$ & 104145.6 & 51482.7 & 3689038.29 & 431733.87 & 157.3 & 152.3 & 378.3 & 380.4 & 380.6 & 228.1 & 4 & PVC & $s$ & 9/9/91 & \\
\hline AMB 4D & Mw. $\overline{P I}$ & 104154.7 & 51489 & 3689041.62 & 431733.9 & 233.4 & 213.4 & 378.4 & 380.3 & & 166.9 & 4 & $\overline{P V C}$ & s & 9/9/91 & \\
\hline$\overline{A M B} 5$ & $\bar{M} \bar{W}, \mathrm{PI}$ & 104083.4 & 51467.2 & 3689020.5 & 431741.19 & 242.1 & 222.1 & 377.6 & 379.6 & 379.8 & 157.5 & $\overline{4}$ & $\overline{P V C}$ & $\bar{s}$ & $9 / 14 / 88$ & \\
\hline$\overline{A M B} 6$ & $\bar{M} w, \overline{P I}$ & 104034.1 & 51466 & 3689007.14 & 431749.47 & 242.6 & 222.6 & 375.1 & 377.2 & 377.4 & 154.6 & 4 & PVC & s & $9 / 15 / 88$ & \\
\hline AMB 7 & $M W, \overline{P I}$ & 103920 & 51624.9 & 3689007.82 & 431809.97 & 242.1 & 222.1 & 368.1 & 369.9 & 370.1 & 147.8 & 4 & $\overline{P V C}$ & s & $9 / 6 / 88$ & \\
\hline$\overline{A M B} \overline{7 A}$ & $\overline{M W}, \bar{P} \mid$ & 103987.1 & 51591 & 3689019.05 & 431789.58 & 125.6 & 115.6 & 371.6 & 373.6 & 373.8 & 258 & 4 & PVC & $s$ & $7 / 26 / 91$ & \\
\hline$\overline{A M B} 7 \mathrm{~B}$ & $\bar{M}, \overline{P l}$ & 103972 & 51590.3 & 3689014.61 & 431791.41 & 162.9 & 152.9 & 370.9 & 373 & 373.1 & 220.1 & 4 & $\overline{P V C}$ & $\bar{s}$ & $7 / 26 / 91$ & \\
\hline$\overline{A M B} 8 \bar{D}$ & $M w, P$ & 103874.7 & 51400.5 & 3688957.16 & 431762.15 & 240.8 & 220.8 & 367.8 & 369.6 & 369.9 & 148.8 & 4 & PVC & $s$ & $10 / 31 / 89$ & \\
\hline AMB $9 D$ & $\overline{M w}, \mathrm{PI}$ & 103585.2 & 51263 & 3688860.57 & 431780.09 & 239.7 & 219.7 & 365.7 & 367.9 & 368.1 & 148.2 & 4 & $\overline{P V C}$ & $\bar{s}$ & $10 / 25 / 89$ & \\
\hline$\overline{A M B} 10 \mathrm{~A}$ & $\overline{M w}, \overline{P I}$ & 103326.4 & 51410 & 3688823.41 & 431862.66 & 111.4 & 106.4 & 364.4 & 366.5 & 366.6 & 260.1 & 4 & PVC & $s$ & $8 / 26 / 91$ & \\
\hline $\bar{A} \overline{M B} 10 \bar{B}$ & $\bar{M}, \overline{P I}$ & 103337.3 & $51 \overline{418.3}$ & 3688827.84 & 431862.69 & 154.3 & $14 \overline{9} . \overline{3}$ & 364.3 & 366.4 & 366.6 & 217.1 & 4 & PVC & $\mathrm{s}$ & $9 / 3 / 91$ & \\
\hline$\overline{A M B} 10 D$ & $\overline{M W}, \overline{P I}$ & 103293.4 & 51456 & 3688823.28 & 431880.34 & 239.4 & 219.4 & $\overline{363 . \overline{4}}$ & 365.5 & 365.8 & 146.1 & 4 & $\overline{P V C}$ & $\mathrm{~s}$ & $11 / 3 / 89$ & \\
\hline AMB 10DD & $M w, P I$ & 103278.7 & 51456 & 3688819.94 & 431883.11 & 358.6 & 338.6 & 363.6 & 365.4 & 365.7 & 26.8 & 4 & PVC & $\mathrm{s}$ & $6 / 7 / 89$ & \\
\hline$\overline{\mathrm{AMB}} \overline{11 \mathrm{~B}}$ & $M w, P I$ & 103154.2 & 51919.5 & 3688872.2 & 432019.35 & 184.5 & 174.5 & 362.5 & 364.6 & 364.7 & 190.1 & 4 & PVC & $s$ & $8 / 13 / 91$ & \\
\hline AMB 11D & $M w, P I$ & 103132.3 & 51932.6 & 3688868.82 & 432026.77 & 240.5 & 220.5 & 362 & 364 & 364.3 & 143.5 & 4 & PVC & $s$ & $6 / 13 / 89$ & \\
\hline AMB 12D & Mw.PI & 103602.4 & 51901.6 & 3688979.23 & 431934.48 & 239.4 & 219.4 & 367.8 & 369.8 & 370.1 & 150.4 & 4 & PVC & 5 & $6 / 16 / 89$ & \\
\hline AMB 13AR & $\overline{M w}, \overline{P I}$ & 103082 & 51396 & 3688761.03 & 431903.17 & 110.9 & 100.9 & 362.9 & 365.1 & 365.2 & 264.2 & 4 & PVC & s & $8 / 8 / 91$ & \\
\hline$\overline{\mathrm{AMH}} 1$ & $\mathrm{Sp}$ & 102654.7 & 48744.2 & 3688179.69 & 431326.68 & & & 361.3 & & & & 2.38 & EUE & & 1988 & \\
\hline$\overline{A M H} 2$ & $S p$ & 102708.8 & 48807.8 & 3688204.04 & 431332.44 & & & 363 & & & & 4.5 & Steel & & 1988 & \\
\hline$\overline{A M H ~} 3$ & $s p$ & 102670.5 & 48779.6 & 3688190.52 & 431332.25 & & & & 362.1 & & & 10 & HDPE & & 1991 & \\
\hline$\overline{A M H ~} 4$ & $s p$ & 102681.1 & 48784.6 & 3688193.96 & 431331.62 & & & & 362.4 & & & 10 & HDPE & & 1991 & \\
\hline
\end{tabular}




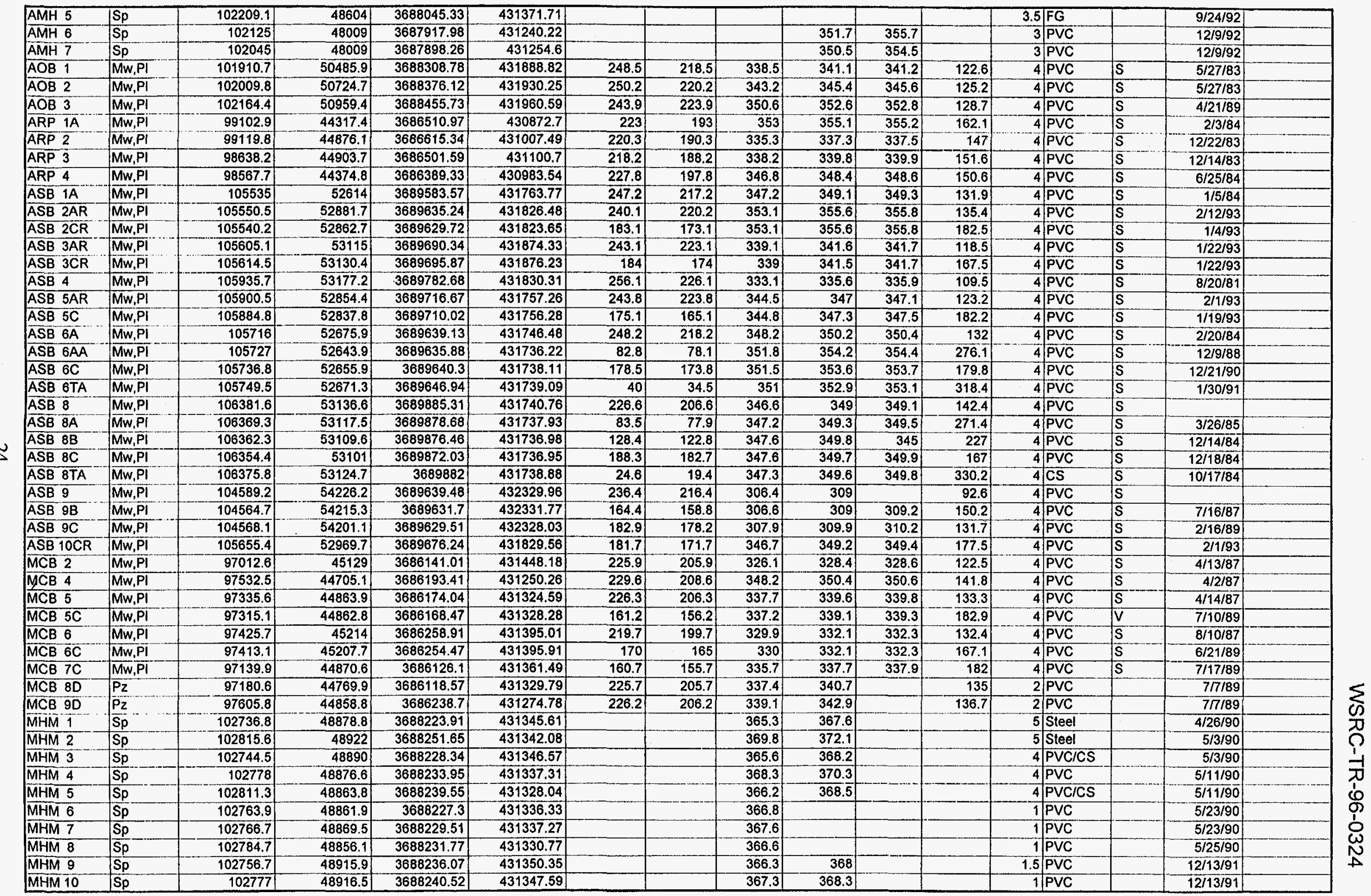




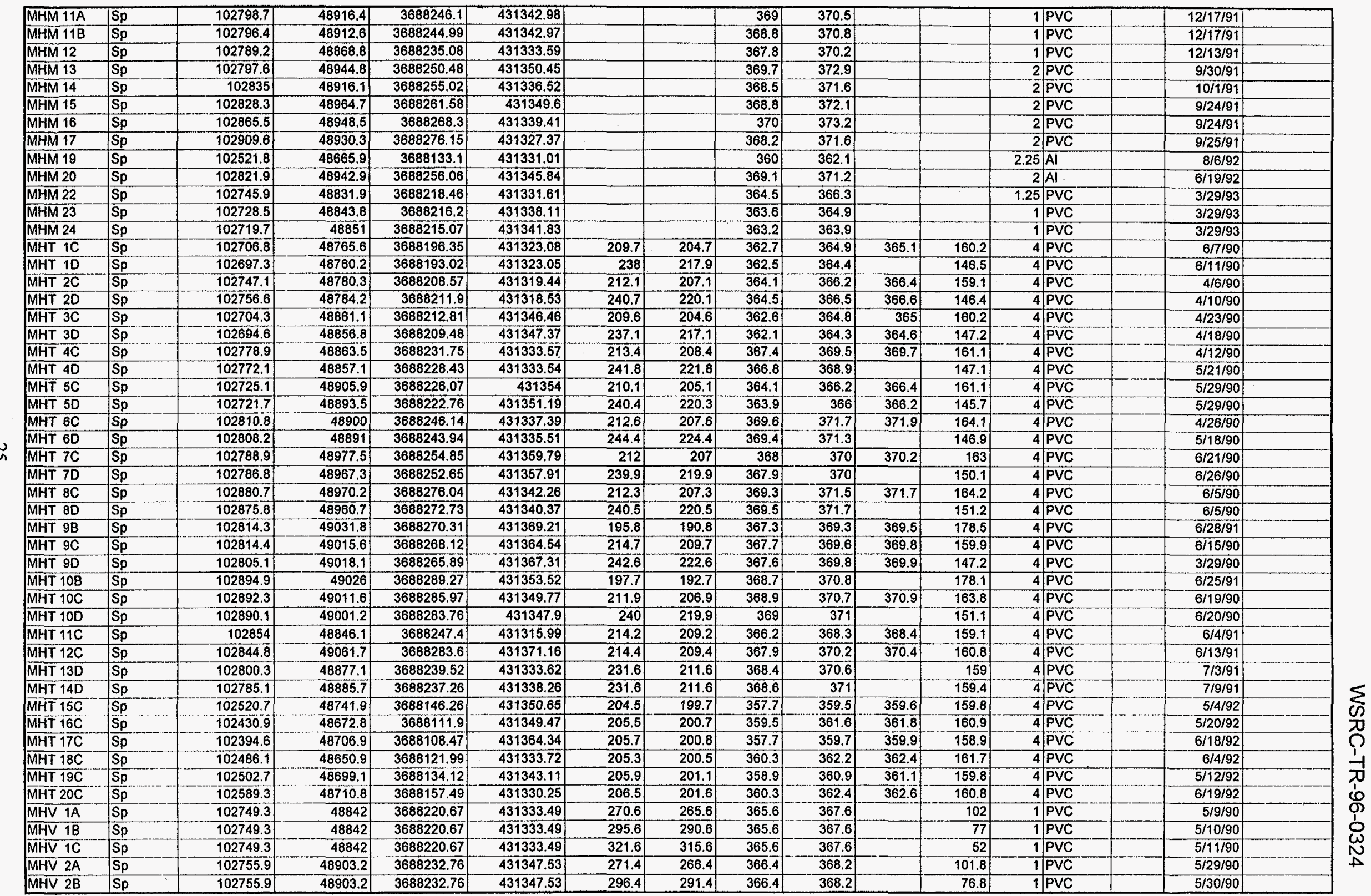




\begin{tabular}{|c|c|c|c|c|c|c|c|c|c|c|c|c|c|}
\hline MHV $2 \mathrm{C}$ & $S p$ & 102755.8 & 48903.2 & 3688232.76 & 431347.53 & 322.4 & 317.4 & 366.4 & 368.2 & 50.8 & $1 \mathrm{PVC}$ & $5 / 31 / 90$ & \\
\hline MHV 3A & $S p$ & 102774.7 & 48874.1 & 3688232.84 & 431337.3 & 273.2 & 288.2 & 368.2 & 370.3 & 102.1 & $1 \mid \mathrm{PVC}$ & $5 / 14 / 90$ & \\
\hline MHV 3B & $S p$ & 102774.7 & 48874.1 & 3688232,84 & 431337.3 & 298.8 & 293.8 & 368.2 & 370.3 & 78.5 & $1 \mid \mathrm{PVC}$ & $5 / 15 / 90$ & \\
\hline MHV $3 C$ & Sp & $\begin{array}{l}102774.7 \\
\end{array}$ & 48874.1 & 3688232.84 & 431337.3 & 323.2 & 318.2 & 368.2 & 370.3 & 52.1 & \begin{tabular}{l|l|l} 
PVC \\
\end{tabular} & $5 / 16 / 90$ & \\
\hline MHV 4A & $S p$ & 102841.7 & 48842.5 & 3688242.85 & 431317.82 & 272.1 & 267.1 & 366.1 & 368.6 & 101.5 & 1/PVC & $6 / 13 / 90$ & \\
\hline MHV $4 \mathrm{~B}$ & $S p$ & 102841.7 & 48.842 .5 & 3688242.95 & 431317.82 & 296.1 & 291.1 & 368.1 & 368.5 & 77.4 & 1 PVC & $6 / 15 / 90$ & \\
\hline MHV 4C & $S p$ & 102841.7 & 48842.5 & 3688242.85 & 431317.82 & 323.6 & 318.6 & 366.1 & 368.7 & 50.1 & $\overline{1} \mid \overline{P V C}$ & $6 / 18 / 90$ & \\
\hline MHV 5A & $S p$ & 102878.8 & 48917.5 & 3688266.16 & 431329,16 & 284.2 & 279.2 & 369.2 & 371.6 & 92.4 & $1 \overline{P V C}$ & $6 / 6 / 90$ & \\
\hline MHV 5B & Sp & 102878.8 & 48917.5 & 3688286.18 & 431329.16 & 301.2 & 296.2 & 369.2 & 371.5 & 75.3 & $1 / \mathrm{PVC}$ & $6 / 7 / 90$ & \\
\hline MHV 5C & $S p$ & 102878.8 & 48917.5 & 3688266.16 & 431329.16 & 324.2 & 319.2 & 369,2 & 371,6 & 52,4 & 1 PVC & $6 / 8 / 90$ & \\
\hline MHV 6 & $S p$ & 102780.1 & 48891.5 & 3688237.25 & 431340.12 & 358.8 & 253.8 & 368.1 & 368,4 & 114.6 & \begin{tabular}{l|l|}
4 & PVC \\
\end{tabular} & $6 / 25 / 91$ & \\
\hline MHV 7 & $S p$ & 102811.5 & 48878.1 & 3688242.85 & 431331.78 & 358.2 & 253.2 & 368.2 & 370.3 & 117.1 & 4 PVC & $6 / 21 / 91$ & \\
\hline MHV 8 & $S p$ & 102610.3 & 48846.3 & 3688187.22 & 431360.24 & 323.4 & 321.1 & 357.7 & 358.6 & 117.4 & \begin{tabular}{l|l} 
PVC \\
\end{tabular} & $4 / 10 / 92$ & \\
\hline MHV 9 & $S p$ & 102830.1 & 49046.7 & 3688276.85 & 431370.18 & 343.5 & $-341,2$ & 367.7 & 369,3 & 123.6 & 4/PVC & $4 / 16 / 92$ & \\
\hline MHV 10 & $s p$ & 102778.6 & 48825,7 & 3688225.17 & 431324.21 & & & 364 & 366.9 & & & $7 / 31 / 92$ & \\
\hline MHV 11 & $S p$ & 102761.8 & 48842.6 & 3688224.01 & 431331.65 & & & 365.5 & 368.5 & & & $7 / 30 / 92$ & \\
\hline MHV 12 & $S p$ & 102743.2 & 48860.2 & 3688222.85 & 431339.08 & & & 365.5 & 368.5 & & & $.7 / 31 / 92$ & \\
\hline MHV 20A & $S p$ & 102418.4 & 48658.3 & 3688106.37 & 431347.57 & 311.6 & 306.7 & 359.6 & 361.8 & 55.1 & $1 / \mathrm{PVC}$ & $12 / 4 / 92$ & \\
\hline MHV 20B & $S p$ & 102418.4 & 48658.3 & 3688106.37 & 431347.57 & 321,6 & 318.7 & 359.6 & 361.7 & 45 & 1 PVC & $12 / 4 / 92$ & \\
\hline MHV 20C & $S p$ & 102418.4 & 48658,3 & 3688106.37 & 431347.57 & 331,6 & 326.7 & 359,6 & 361.7 & 35 & 1/PVC & $12 / 4 / 92$ & \\
\hline MHV 20T & $S p$ & 102420.5 & 48649,8 & 3688105.27 & 431345.7 & & & & & & 2 PVC & $1 / 22 / 93$ & \\
\hline MHV 21A & $S p$ & 102433.6 & 48661.5 & 3688110.82 & 431345.74 & 311.7 & 306.8 & 359,7 & 362 & 55.2 & \begin{tabular}{l|l} 
PVC \\
.
\end{tabular} & $12 / 4 / 92$ & \\
\hline MHV 21B & $S p$ & 102433.8 & 48661.5 & 3688110.82 & 431345.74 & 321.7 & 316,8 & 359,7 & 362 & 45.2 & $1 / \mathrm{PVC}$ & $12 / 4 / 92$ & \\
\hline MHV 21C & $S p$ & 102433,6 & 48661.5 & 3688110.82 & 431345.74 & 331.7 & 326.8 & 359,7 & 362 & 35.2 & $1 / \overline{P V C}$ & $12 / 4 / 92$ & \\
\hline$\overline{M H V} 21 \mathrm{~T}$ & $\overline{s p}$ & 102435.5 & 48653.5 & 3688109.72 & 431343.87 & & & & & & $\begin{array}{l}2 \text { PVC } \\
\end{array}$ & $1 / 22 / 93$ & \\
\hline MHV 22A & $S p$ & 102443.5 & 48663.8 & 3688113.04 & 431344.83 & 311.7 & 308.8 & 359.7 & 362 & 55.2 & \begin{tabular}{l|l|l|} 
PVC \\
\end{tabular} & $12 / 4 / 92$ & \\
\hline MHV 22B & $S p$ & 102433.5 & 48663.8 & 3688110.81 & 431346.67 & 321.7 & 316.8 & 359.7 & 362 & 45,2 & $1 \mathrm{PVC}$ & $12 / 4 / 92$ & \\
\hline MHV 22C & $s p$ & 102433.5 & 48663.8 & 3688110.81 & 431348.67 & 331.7 & 326.8 & 350.7 & 362 & 35,2 & 1 PVC & $12 / 4 / 92$ & \\
\hline MHV 22T & $S p$ & 102446 & 48657.1 & 3888113.05 & 431342,86 & & & & & & \begin{tabular}{l|l|}
2 & $P V C$ \\
\end{tabular} & $1 / 22 / 93$ & \\
\hline MHV 23A & $S p$ & 102458 & 48666,9 & 3688117.49 & 431343 & 311.7 & 306.8 & 358.7 & 361.8 & 55.1 & \begin{tabular}{l|l|l} 
PVC \\
\end{tabular} & $12 / 4 / 92$ & \\
\hline MHV 23B & $S p$ & 102458 & 48686,9 & 3688117.49 & 431343 & 321.7 & 316.8 & 359.7 & 361.9 & 45.1 & $1 \longdiv { P V C }$ & $12 / 4 / 92$ & \\
\hline MHV 23C & $s p$ & 102458 & 48666.8 & 3688117.49 & 431343 & 331.7 & 326.8 & 359.7 & 362 & 35.2 & $1 \mathrm{PVC}$ & $12 / 4 / 92$ & \\
\hline MHV 23T & $S p$ & 102460.8 & 48661 & 3688117.5 & 431341.13 & & & & & & 2 PVC & $1 / 22 / 93$ & \\
\hline MHV 24A & $S p$ & 102439.8 & 48636.9 & 3688107.54 & 431339.2 & 312.5 & 307.6 & 360.5 & 362.7 & 55.1 & 1) PVC & $12 / 4 / 92$ & \\
\hline MHV 24B & $S p$ & 102439.8 & 48836.9 & 3688107.54 & 431339,2 & 322.5 & 317.6 & 360.5 & 3627 & 45.1 & 1 PVC & $12 / 4 / 92$ & \\
\hline MHV 24C & $\mathrm{sp}$ & 102438.8 & 48636.9 & 3688107.54 & 431339.2 & 332.5 & 327.6 & 360.5 & 362.8 & 35.2 & $1 / P V C$ & $12 / 4 / 92$ & \\
\hline MHV 24T & $S p$ & 102442.6 & 48640.9 & 36.88108 .65 & 431339.21 & & & & & & $2 \mid P V C$ & $1 / 22 / 93$ & \\
\hline MHV 25A & $\mathrm{sp}$ & 102428.8 & 48681 & 3688113 & 431351.34 & 311.1 & 306,2 & 359.1 & 361.5 & $55 . \overline{3}$ & $1 / P V C$ & $12 / 4 / 92$ & \\
\hline MHV 25B & Sp & 102428.9 & 48681 & 3688113 & 431351.34 & 321.1 & 316.2 & 359.1 & 361.5 & 45.3 & \begin{tabular}{l|l|} 
PVC \\
\end{tabular} & $12 / 4 / 92$ & \\
\hline MHV 25C & $\overline{\mathrm{sp}}$ & 102428.9 & 48681 & 3688113 & 431351.34 & 331.1 & 326.2 & 359.1 & 361.5 & 35.3 & $1 / \overline{P V C}$ & $12 / 4 / 92$ & \\
\hline MHV 25T & $s p$ & 102424.5 & 48679 & 36.88111 .88 & 431352.26 & & & & & & \begin{tabular}{l|l|}
2 & $P V C$
\end{tabular} & $1 / 22 / 93$ & \\
\hline MHV 26A & $\mathrm{Sp}$ & 102404.2 & 48655.3 & 3688101.82 & 431349.4 & 311.8 & 308.9 & 359.8 & 382.1 & 55.2 & \begin{tabular}{l|l|l}
1 & $P V C$ \\
\end{tabular} & $12 / 4 / 92$ & \\
\hline MHV 26B & $S p$ & 102404.2 & 48655.3 & 3688101.82 & 431349,4 & 321,8 & 316.9 & 359.8 & 362.1 & 45.2 & $1 / \mathrm{PVC}$ & $12 / 4 / 92$ & \\
\hline MHV 26C & $S p$ & 102404.2 & 48655.3 & 3688101.92 & 431349.4 & 331.8 & 326.9 & 359.8 & 362.1 & 35.2 & 1:PVC & $12 / 4 / 92$ & \\
\hline MHV 26T & $\mathrm{Sp}$ & 102406.1 & 48647.9 & 3688100.83 & 431347.53 & & & & & & 2 PVC & $1 / 22 / 93$ & \\
\hline MHV 27A & $\overline{s p}$ & 102374.3 & 48654.5 & 3688094.12 & 431354.83 & 311,9 & 307 & 359.8 & 362.1 & 55.1 & 1 PVC & $12 / 4 / 92$ & \\
\hline MHV 27B & $s p$ & $\begin{array}{l}102374.3 \\
\end{array}$ & 48654.5 & 3688094.12 & 431354,93 & 321.9 & 317 & 359.9 & 362 & 45 & 1 PVC & $12 / 4 / 92$ & \\
\hline$\overline{M H V} 27 \mathrm{C}$ & $S p$ & 102374.3 & 48654.5 & 3688094.12 & 431354.93 & 331.9 & 327 & 359.9 & 362.1 & 35.1 & $1 \mid P V C$ & $12 / 4 / 92$ & \\
\hline MHV 27T & $S p$ & 102380,4 & 48650.3 & 3688095.24 & 431353.08 & & & & & & 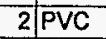 & $1 / 22 / 93$ & \\
\hline MHV 28A & $\mathrm{Sp}$ & 102368.3 & 48647.6 & 3688091.9 & 431354.91 & 311.8 & 307 & 359.8 & 362.2 & 55.2 & $1 \mid \overline{P V C}$ & $12 / 4 / 92$ & \\
\hline
\end{tabular}




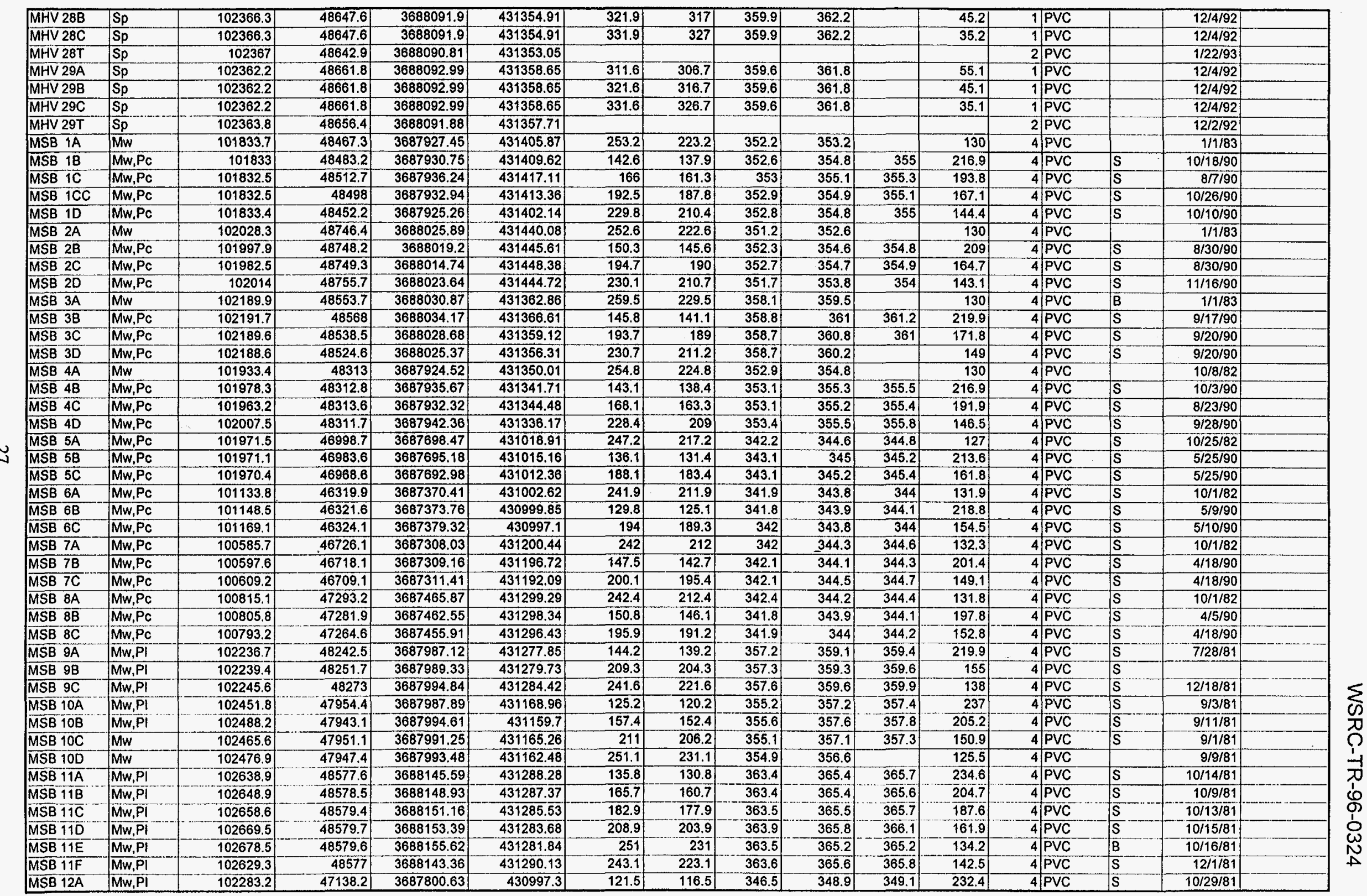




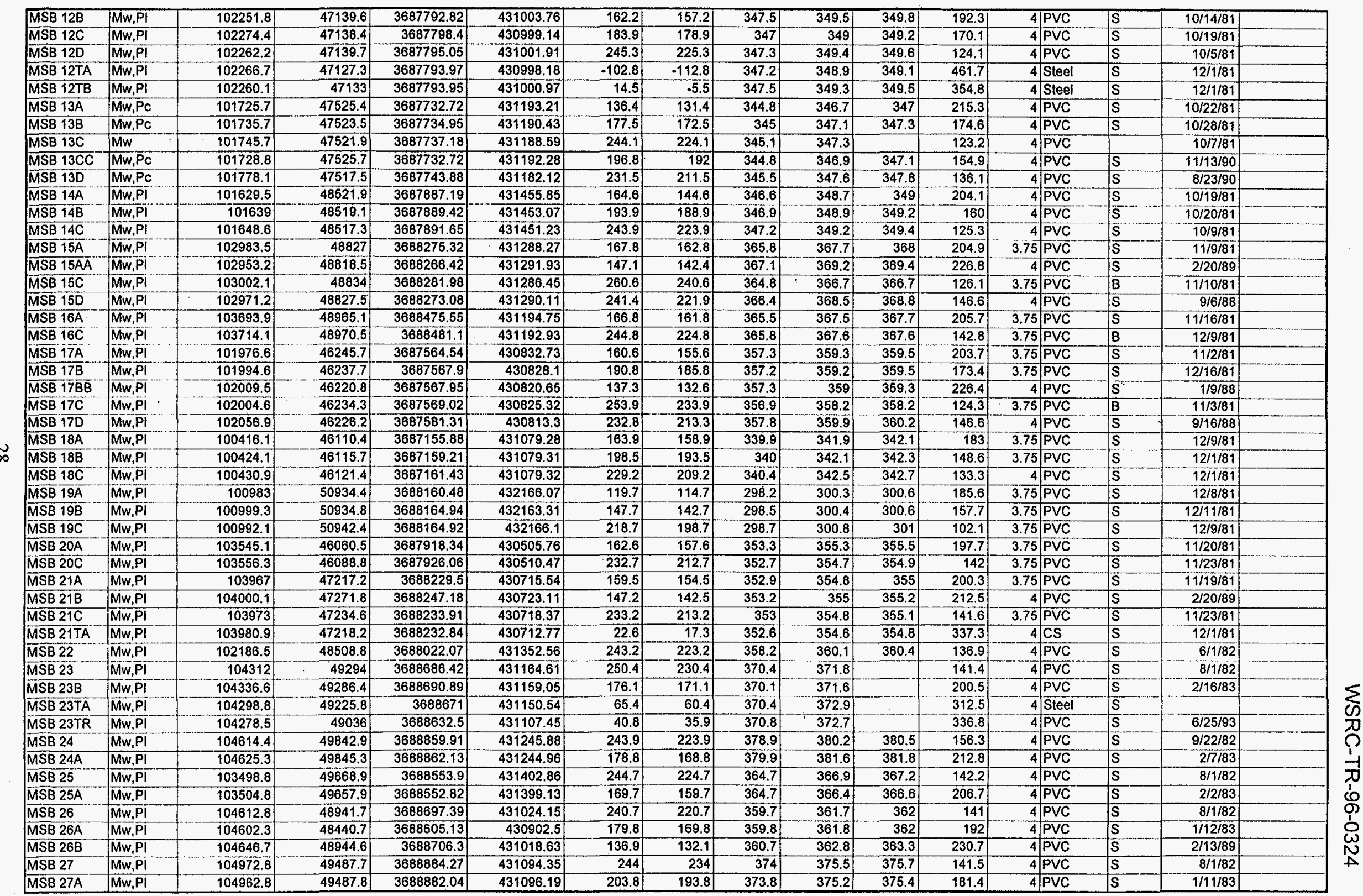




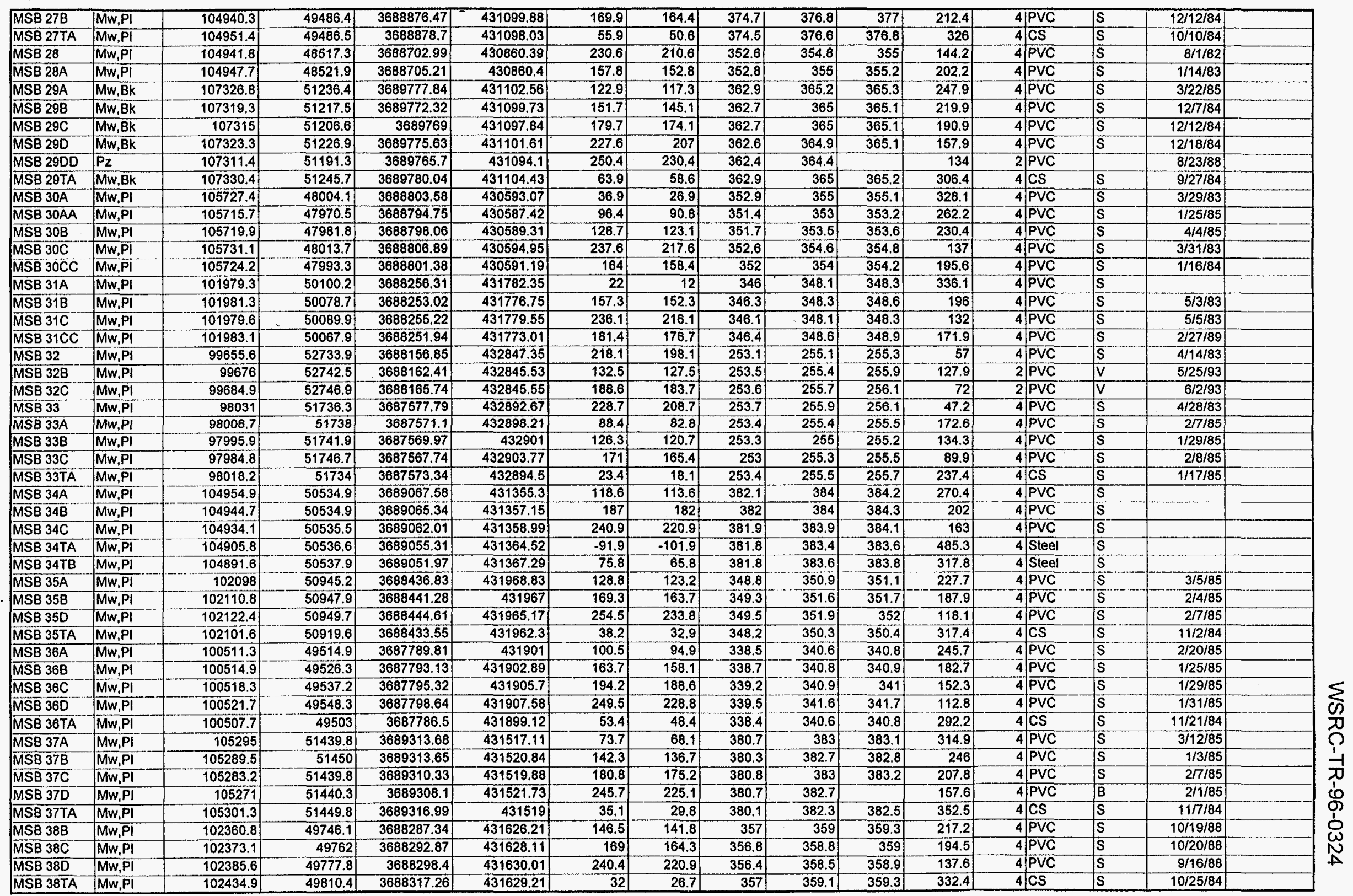




\begin{tabular}{|c|c|c|c|c|c|c|c|c|c|c|c|c|c|c|}
\hline MSB 39A & $M w, P I$ & 100837.6 & 48367.3 & 3687664.71 & 431559.46 & 111.7 & 106.1 & 339.7 & 341.6 & 341.7 & 235.5 & 4 PVC & 5 & $3 / 8 / 85$ \\
\hline MSB 398 & Mw,PI & 100844.6 & 48376.9 & 3687668.03 & 431561.34 & 149.8 & 144 & 339.6 & 341.8 & 342 & 197.8 & $4 \overline{\mathrm{PVC}}$ & s & $1 / 7 / 85$ \\
\hline MSB 39C & Mw,PI & 100852.1 & 48386.7 & 3687671.34 & 431562.3 & 199.6 & 194 & 339.7 & 341.5 & 341.7 & 147.5 & \begin{tabular}{l|l|l|}
4 & $P V C$ \\
\end{tabular} & $S$ & 1/1/85 \\
\hline MSB 39D & $\overline{M w}, P \mid$ & 100858.7 & 48396 & 3687674.66 & 431563.25 & 239.7 & 219 & 339.7 & 341.8 & 341.9 & 122.8 & 4 PVC & s & $1 / 14 / 85$ \\
\hline MSB 39TA & $M W, P I$ & 100830.6 & 48357.7 & 3687661.39 & 431558.5 & 49.7 & 44.4 & 339.7 & 341.8 & 342 & 297.4 & \begin{tabular}{l|l}
$\mathrm{CS}$ \\
\end{tabular} & s & $10 / 4 / 84$ \\
\hline MSB 40A & $\bar{M} w, P I$ & 97672.8 & 48279.4 & 3686869.25 & 432105.85 & 116.2 & 110.6 & 319.2 & 321.2 & 321.4 & 210.6 & $4 \mid \mathrm{PVC}$ & s & $3 / 1 / 85$ \\
\hline MSB 40B & $M w, P I$ & 97685 & 48281.6 & 3686872.59 & 432104.01 & 154.7 & 149.1 & 319.7 & 321.7 & 321.8 & 172.6 & $4 \mid \overline{P V C}$ & 5 & $1 / 31 / 85$ \\
\hline MSB 40C & $\overline{M w}, \mathrm{PI}$ & 97697.8 & 48283.5 & 3686875.93 & 432102.17 & 192.4 & 186.8 & 320.4 & 322 & 322.2 & 135.2 & \begin{tabular}{l|l|}
4 & PVC
\end{tabular} & $s$ & $2 / 4 / 85$ \\
\hline MSB 40D & $M w, P I$ & 97709.3 & 48285.1 & 3686879.27 & 432100.34 & 236.8 & 216.2 & 320.8 & 322.9 & 323.1 & 106.7 & 4 PVC & $B$ & $2 / 7 / 85$ \\
\hline MSB 40TA & $M w, \overline{P I}$ & 97660.4 & 48277.2 & 3686865.91 & 432107.69 & 29 & 23.7 & 319 & 320.9 & 321.1 & 297.2 & \begin{tabular}{l|l|}
$4 \mathrm{CS}$ \\
\end{tabular} & s & $11 / 30 / 84$ \\
\hline MSB 41A & $M w, P I$ & 102184.4 & 53424.1 & 3688902.77 & 432564 & 87.9 & 82.3 & 321.9 & 323.8 & 324 & 241.5 & 4 PVC & $S$ & $12 / 13 / 84$ \\
\hline MSB 41B & MW,PI & 102194.5 & 53417.8 & 3688905.01 & 432560.3 & 114.2 & 108.6 & 322.2 & 324 & 324.2 & 215.4 & 4 PVC & s & $2 / 25 / 85$ \\
\hline MSB 41C & $\bar{M}, \mathrm{PI}$ & 102203.9 & 53410.6 & 3688905.03 & 432557.51 & 152.5 & 146.9 & 322.5 & 324.6 & 324.8 & 177.7 & $4 \mid \mathrm{PVC}$ & $\mathrm{s}$ & $2 / 11 / 85$ \\
\hline MSB 41D & Mw,PI & 102213.4 & 53403.7 & 3688906.17 & 432553.79 & 247.8 & 227.1 & 322.8 & 325 & 325.1 & 97.9 & 4 PVC & s & $2 / 13 / 85$ \\
\hline$\overline{M S B}$ 41TA & Mw,PI & 102176.5 & 53429.7 & 3688902.75 & 432566.8 & 26.7 & 21.4 & 321.7 & 323.7 & 323.9 & 302.3 & \begin{tabular}{l|l}
4 & $\mathrm{CS}$ \\
\end{tabular} & $\mathbf{s}$ & $1 / 11 / 85$ \\
\hline$M$ & MW,Pl & 104557.9 & 51582.3 & 3689157.28 & 431684.46 & \begin{tabular}{|c|}
129.4 \\
\end{tabular} & 123.8 & 374.4 & 376.5 & \begin{tabular}{|c|}
376.7 \\
\end{tabular} & 252.7 & \begin{tabular}{l|l|}
$4 V C$ \\
\end{tabular} & s & $3 / 19 / 85$ \\
\hline MSB 42B & $M w, P$ & 104569.8 & 51582.8 & 3689160.61 & 431682.62 & 166.3 & 160.7 & 374.3 & 376.4 & 376.6 & 215.7 & 4 PVC & s & $1 / 16 / 85$ \\
\hline MSB 42C & $\bar{M}, \mathrm{PI}$ & 104581.9 & 51582.8 & 3689163.95 & 431680.78 & 204.3 & 198.7 & 374.3 & 376.4 & 376.5 & 177.7 & \begin{tabular}{l|l|l}
4 & PVC
\end{tabular} & $\mathrm{s}$ & $1 / 24 / 85$ \\
\hline MSB 42D & $M w, P I$ & 104595.2 & 51582.5 & 3689167.3 & 431678.01 & 247.2 & 226.6 & 374.2 & 376.4 & 376.5 & 149.8 & $4 \mid \mathrm{PVC}$ & $\bar{B}$ & $1 / 30 / 85$ \\
\hline MSB 42TA & $M w, P I$ & 104545.8 & 51581.7 & 3689153.94 & 431686.29 & 45.8 & 40.5 & 374.5 & 376.6 & 376.8 & 336.1 & \begin{tabular}{l|l|}
$4 \mathrm{CS}$ \\
\end{tabular} & $\mathrm{s}$ & $10 / 31 / 84$ \\
\hline$\overline{M S B} 43 A$ & $\bar{M} w, B k$ & 107275.3 & 49293.7 & 3689416.41 & 430633.75 & 140.5 & 134.9 & 355.5 & 357.7 & 357.9 & 222.8 & \begin{tabular}{l|l}
4 & PVC
\end{tabular} & $\bar{s}$ & $4 / 1 / 85$ \\
\hline$\overline{\mathrm{MSB}} 43 \mathrm{~B}$ & $M w, B k$ & 107274.6 & 49311.8 & 3689419.7 & 430638.43 & 175.5 & 169.9 & 355.5 & 357.8 & 358 & 187.9 & \begin{tabular}{l|l|l}
4 & PVC
\end{tabular} & $\mathrm{s}$ & $12 / 12 / 84$ \\
\hline MSB 43D & $M w, B k$ & 107274.2 & 49322 & 3689421.91 & 430640.3 & 220.8 & 200.2 & 355.8 & 358 & 358.1 & 157.8 & \begin{tabular}{l|l}
4 & PVC
\end{tabular} & s & $1 / 3 / 85$ \\
\hline MSB 43DD & Pz & 107273 & 49341.2 & 3689424.09 & 430645.9 & 243.2 & 223.1 & 356.2 & 357,9 & & 134.8 & \begin{tabular}{|l|l|}
2 & $P V C$ \\
\end{tabular} & & $8 / 23 / 88$ \\
\hline$\widehat{\text { MSB 43TA }}$ & $M w, B k$ & 107275.8 & 49281.8 & 3689414.21 & 430630.94 & 40.3 & 35 & 355.3 & 357.5 & 357.6 & 322.5 & \begin{tabular}{l|l|}
4 & $\mathrm{CS}$
\end{tabular} & s & $9 / 25 / 84$ \\
\hline$\overline{M S B} 44 A$ & $M W, P I$ & 103296.5 & 51106.9 & 3688761.81 & 431783.35 & 134.6 & 124.6 & 374.4 & 376.9 & 377.1 & 252.3 & $\begin{array}{l}4 / P V C \\
\end{array}$ & s & \\
\hline $\bar{M} \overline{S B}$ 44B & MW,PI & 103296.2 & 51096.4 & 3688759.6 & 431791.48 & 184.6 & 174.6 & 374.6 & 377 & 377.1 & 202.4 & $4 \mid$ PVC & is & \\
\hline MSB 44C & $M w_{1} \overline{P I}$ & 103296.3 & 51106.6 & 3688761.81 & 431793.35 & 239.4 & 229.4 & 374.4 & 376.8 & 376.8 & 147.4 & $2 \mid \overline{P V C}$ & 8 & \\
\hline$\overline{M S B}$ 45A & Mw,PI & 103998.1 & 50554.7 & 3688835.71 & 431532.35 & 139.2 & 129.2 & 378.4 & 380.8 & 381.1 & 251.6 & \begin{tabular}{l|l|l|} 
& PVC
\end{tabular} & $\mathrm{s}$ & \\
\hline MSB 45B & $M w, P I$ & 103987.9 & 50555.3 & 3688833.48 & 431534.2 & 190 & 180 & 378.3 & 380.9 & 381.1 & 200.9 & 4 PVC & s & \\
\hline$\overline{M S B} 45 \mathrm{C}$ & $M w_{1} P I$ & 103997.7 & 50554.7 & 3688835.71 & 431532.35 & 243.7 & 233.4 & 378.4 & 380.8 & 380.8 & 147.4 & 2 PVC & $\mathrm{B}$ & \\
\hline MSB 46A & $M w, P I$ & 103098.6 & 50548.3 & 3688612.84 & 431691.79 & 130 & 120 & 370 & 372.6 & 372.8 & 252.6 & 4 PVC & s & \\
\hline MSB 46B & $M w, P \mid$ & 103102.4 & 50557.5 & 3688615.05 & 431693.67 & 189.8 & 179.8 & 370.8 & 373,6 & 373.7 & 193.8 & \begin{tabular}{l|l|}
4 & PVC
\end{tabular} & s & \\
\hline MSB 46C & $M W, P \mid$ & 103098.5 & 50548.7 & 3688612.84 & 431691.79 & 247 & 237 & 370 & 372.6 & 372.6 & 135.6 & \begin{tabular}{l|l|l|} 
PVC & \\
\end{tabular} & B & \\
\hline MSB 47B & Mw,Pl & 106978.5 & 52207.2 & 3689865.5 & 431404.69 & 171.5 & 165.9 & 366.7 & 368.7 & 368.9 & 202.8 & \begin{tabular}{l|l|}
4 & PVC
\end{tabular} & $\mathrm{s}$ & $7 / 10 / 87$ \\
\hline$\overline{M S B} 47 \mathrm{BB}$ & $\bar{M} w, P I$ & 106999.7 & 52234.4 & 3689876.57 & 431407.56 & 120.3 & 115.6 & 366.3 & 368.8 & 369 & 253.2 & \begin{tabular}{l|l}
4 & $\overline{P V C}$
\end{tabular} & s & $10 / 16 / 89$ \\
\hline MSB $47 \mathrm{C}$ & $M w, P l$ & 106969.2 & 52195.5 & 3689861.08 & 431403.73 & 202.6 & 197 & 366.8 & 369 & 369.1 & 172 & \begin{tabular}{l|l}
4 & PVC
\end{tabular} & s & $7 / 14 / 87$ \\
\hline MSB 470 & $\bar{M} w, P I$ & 106960.1 & 52184 & 3689857.76 & 431401.84 & 246.1 & 226.5 & 366.6 & 368,8 & 369 & 142.3 & \begin{tabular}{l|l}
4 & PVC
\end{tabular} & 5 & $8 / 7 / 87$ \\
\hline$\overline{M S B}$ 47TA & $M w, P I$ & 106987.7 & 52219 & 3689869.93 & 431405.65 & 55.1 & 50.1 & 366.2 & 368.7 & 368.8 & 318.6 & $4 \mathrm{CS}$ & $s$ & $6 / 22 / 87$ \\
\hline$\overline{M S B} 4 \overline{A B}$ & $\bar{M} w, \overline{P I}$ & 107936.6 & 54099.8 & 3690441.07 & 431699.08 & 129.4 & 124.7 & 359.4 & 361.6 & 361.8 & 236.9 & \begin{tabular}{l|l|}
4 & $P V C$ \\
\end{tabular} & s & $1 / 12 / 90$ \\
\hline$\overline{M S B} 48 B$ & $\bar{M} w \bar{P} \mid$ & 107945 & 54112.2 & 3690445.49 & 431700.97 & 158.3 & 153.6 & 359.3 & 361.4 & 361.6 & 207.8 & $4 \overline{\mathrm{PVC}}$ & $s$ & $1 / 16 / 90$ \\
\hline MSB 48C & $\overline{M w}, \mathrm{PI}$ & 107917.5 & 54077 & 3690432.21 & 431697.16 & 180.2 & 175.4 & 360.2 & 362.3 & 362.5 & 186.9 & $4 / \mathrm{PVC}$ & $s$ & $5 / 25 / 89$ \\
\hline$\overline{M S B} 48 D$ & $M w, P l$ & 107914.4 & 54056.3 & 3690427.81 & 431692.47 & 243.5 & 222 & 360.5 & 362.6 & 362.8 & 140.6 & \begin{tabular}{l|l}
4 & $\overline{P V C}$ \\
\end{tabular} & $s$ & \\
\hline$\overline{M S B}$ 4BTA & $M w, P I$ & 107925.8 & 54089.2 & 3690436.64 & 431698.12 & 107.8 & 102.5 & 359.8 & 361.9 & 362.1 & 259.4 & \begin{tabular}{l|l}
$4 \mathrm{CS}$ \\
\end{tabular} & s & $1 / 15 / 90$ \\
\hline$\overline{M S B} 4 \overline{49 A}$ & $M w, P \mid$ & 99759 & 45864.6 & 3686950.36 & 431136.47 & 76.7 & 72 & 332.7 & 334.7 & 334.9 & 262.7 & $4 \mid \overline{P V C}$ & $s$ & $1 / 20 / 89$ \\
\hline MSB 49B & $\overline{M w}, \mathrm{PI}$ & 99737.8 & 45868.2 & 3686945.9 & 431141.09 & 116.3 & 110.7 & 331.8 & 334.1 & 334.8 & 223.4 & \begin{tabular}{l|l|l}
4 & PVC \\
\end{tabular} & s & $7 / 31 / 87$ \\
\hline MSB 49D & Mw,PI & 99724.9 & 45856.4 & 3686940.35 & 431141.05 & 236.4 & 216.7 & 331.8 & 334.3 & 334.4 & 117.6 & \begin{tabular}{l|l|}
4 & PVC \\
\end{tabular} & $\mathrm{s}$ & $8 / 10 / 87$ \\
\hline$\overline{M S B}$ 5OB & $M w, P I$ & 96433 & 51053.5 & 3687061.42 & 433011.04 & 155.2 & 149.6 & 221.3 & 223.7 & 223.9 & 74.1 & \begin{tabular}{l|l|l}
4 & PVC
\end{tabular} & s & $5 / 20 / 87$ \\
\hline MSB SOD & $\bar{M}, \mathrm{PI}$ & 96416.7 & 51044.1 & 3687055.87 & 433011.94 & 210.9 & 190.8 & 220.7 & 223.2 & 223.4 & 32.4 & \begin{tabular}{l|l|l|}
4 & PVC
\end{tabular} & $\mathrm{s}$ & $8 / 4 / 87$ \\
\hline MSB 51B & $M w, P \mid$ & 96992.7 & 52818 & 3687515.91 & 433345.54 & 160 & 154.4 & 261.1 & 263.2 & 263.3 & 108.8 & \begin{tabular}{l|l|l|} 
PVC & \\
\end{tabular} & s & $5 / 26 / 87$ \\
\hline
\end{tabular}




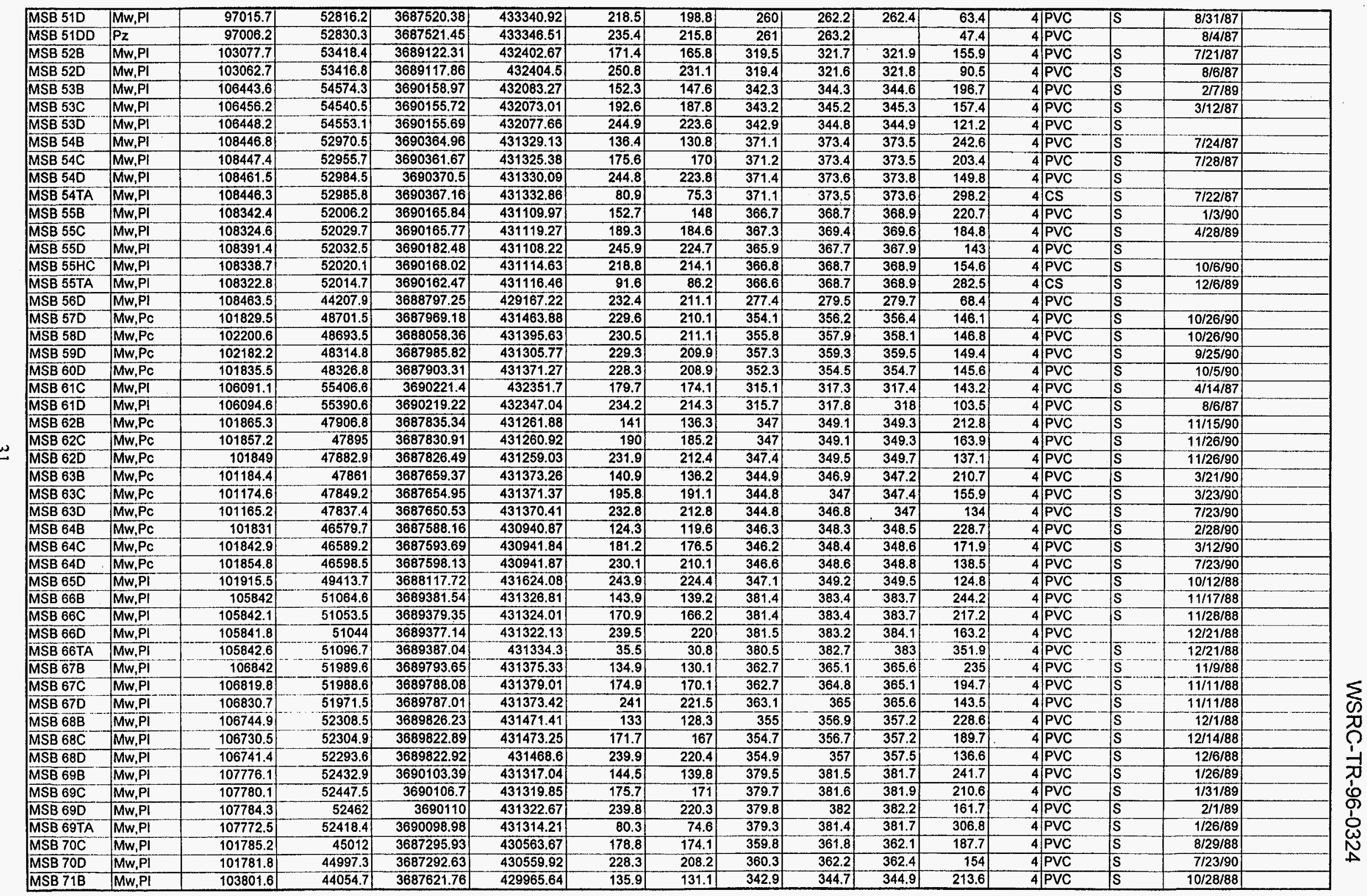




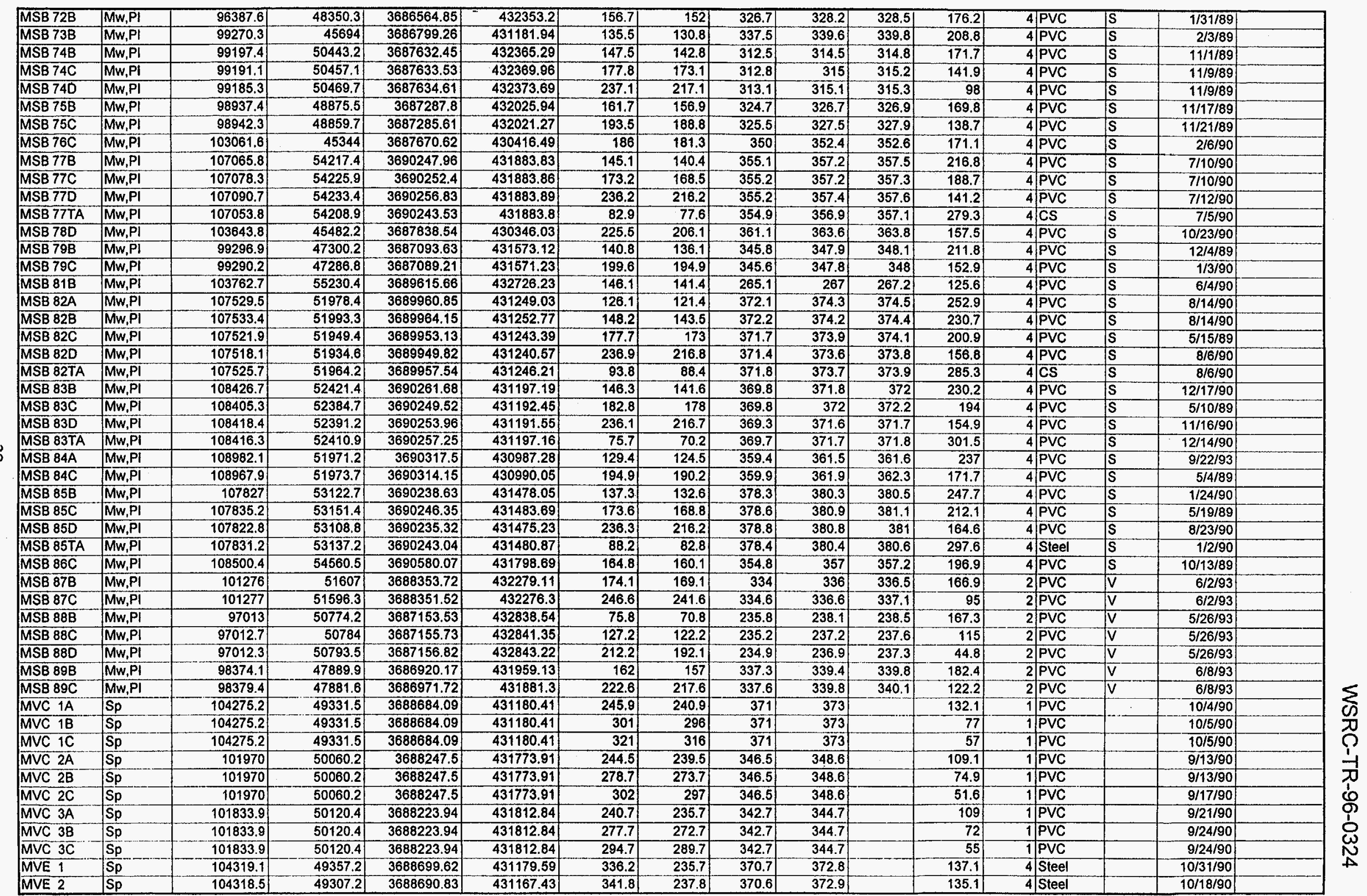




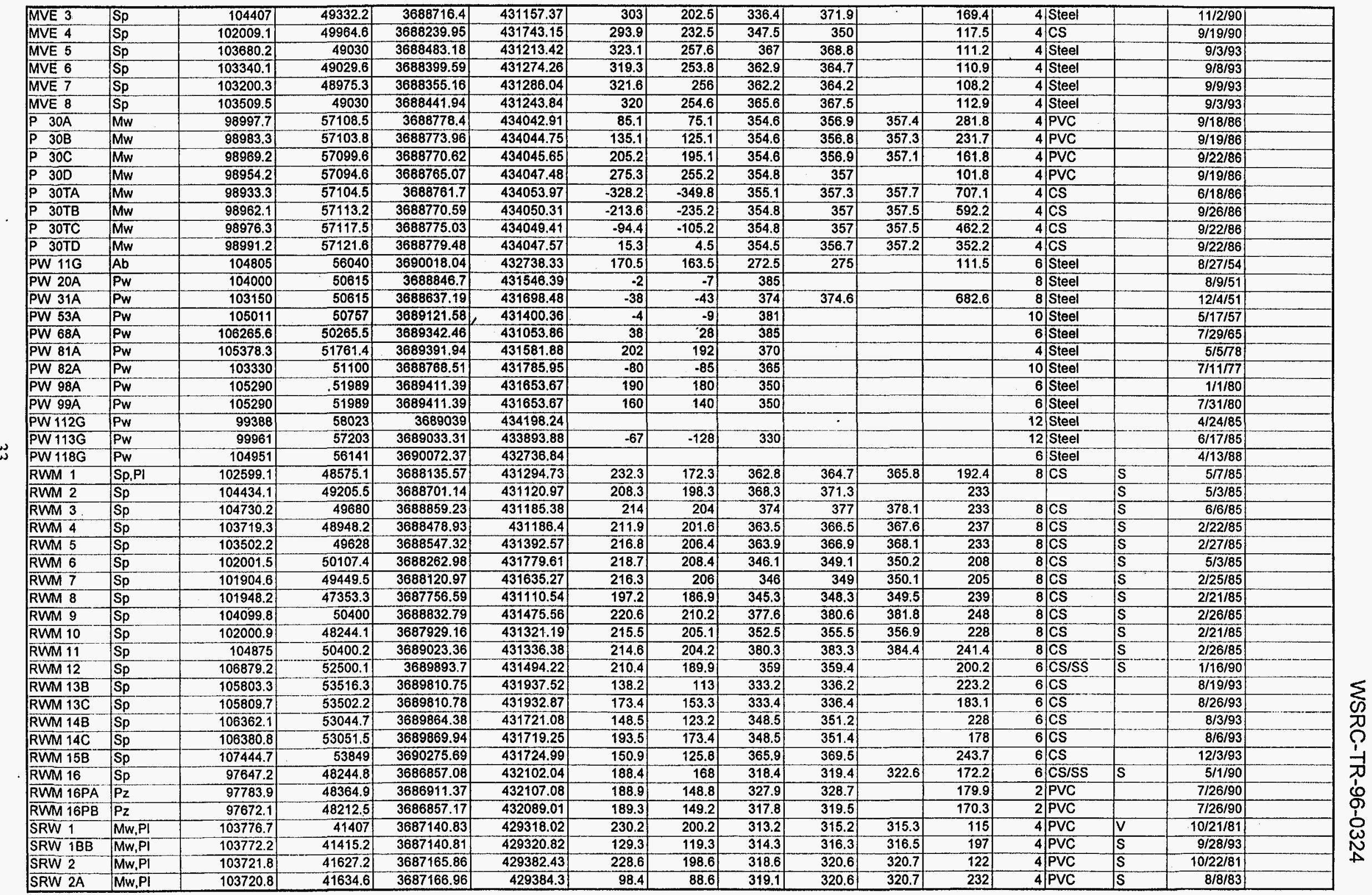




\begin{tabular}{|c|c|c|c|c|c|c|c|c|c|c|c|c|c|c|c|c|}
\hline SRW 2B & $M w, P I$ & 103729.7 & 41631.7 & 3687169.19 & 429381.53 & 162.6 & 152.8 & 319.2 & 320.6 & 320.7 & 167.8 & & PVC & S & $12 / 20 / 83$ & \\
\hline SRW $3 A$ & $M w, P I$ & 103516.4 & 41851.2 & 3687156.32 & 429474.52 & 193.1 & 163.1 & 330.1 & 332.1 & 332.2 & 169 & $4 \mid$ & PVC & s & $8 / 20 / 84$ & \\
\hline SRW 3BB & $M w, P I$ & 103526.6 & 41845.6 & 3687157.46 & 429470.8 & 130.3 & 120.2 & 330.3 & 332.3 & 332.5 & 212.1 & 4 & PVC & $\bar{s}$ & $9 / 23 / 93$ & \\
\hline$\overline{\text { SRW } 4}$ & Mw,PI & 103359.9 & 41612.4 & 3687074.5 & 429443.21 & 230.1 & 200.1 & 318.1 & 320.1 & 320.3 & 120 & 4 & PVC & s & 9/28/81 & \\
\hline SRW 4BB & MW,PI & 103347.9 & 41609,2 & 3687071.16 & 429445.04 & 134.1 & 124 & 318.6 & 320.6 & 320.8 & 196.6 & 4 & PVC & s & $8 / 20 / 93$ & \\
\hline SRW 5 & $M w, P I$ & 103418.2 & 41240 & 3687022.03 & 429341.36 & 224.6 & 194.6 & 307.6 & 309.4 & 309.5 & 114.8 & 4 & $\overline{P V C}$ & s & $10 / 29 / 81$ & \\
\hline$\overline{\text { SRW } 6}$ & $\overline{M W, P I}$ & 103602.7 & 41243.9 & 3687068.83 & 429309.12 & 222.6 & 192.6 & 305.6 & 307.7 & 307.8 & 115.1 & 4 & PVC & s & $11 / 3 / 81$ & \\
\hline SRW 7 & $\overline{M w}, \overline{P I}$ & 103541.5 & 40926.2 & 3686996.14 & 429241.57 & 217.5 & 197.5 & 296.7 & 299.1 & 299.2 & 101.6 & 4 & PVC & s & $5 / 3 / 82$ & \\
\hline SRW 10 & $\mathrm{Mw}, \overline{P I}$ & 103387.9 & 40944.3 & 3686961.54 & 429273.9 & 223 & 193 & 301 & 303.4 & 303.5 & 110.4 & 4 & PVC & s & $9 / 16 / 82$ & \\
\hline SRW 10BB & Mw,PI & 103399.1 & 40940.5 & 3686963.78 & 429271.12 & 126.7 & 116.6 & 300.7 & 302.8 & 302.9 & 186.2 & 4 & PVC & s & 9/16/93 & \\
\hline SRW 11 & Mw,PI & 103693.2 & 40874.2 & 3687024.15 & 429201.75 & 220.6 & 190.6 & 293.6 & 295.8 & 296 & 105.2 & 4 & PVC & s & $9 / 20 / 82$ & \\
\hline SRW 11BB & $M w, \overline{P I}$ & 103703.4 & 40871.2 & 3687026.39 & 429198.97 & 129.5 & 119.5 & 294.5 & 296.5 & 296.7 & 177 & 4 & PVC & s & $9 / 30 / 93$ & \\
\hline SRW 14A & $M w, P I$ & 102831.3 & 41538.6 & 3686930.92 & 429520.35 & 123.7 & 113.9 & 324.9 & 327 & 327.1 & 213.1 & 4 & PVC & s & $9 / 3 / 83$ & \\
\hline SRW 14B & $M w, P I$ & 102836.1 & 41548.1 & 3686934.24 & 429521.31 & 162.9 & 153.1 & 324.9 & 326.9 & 327 & 173.8 & 4 & PVC & s & $12 / 16 / 83$ & \\
\hline SRW 14C & Mw,PI & 102824.2 & 41546.4 & 3686930.9 & 429523.15 & 228.3 & 198.6 & 325.3 & 326.0 & 327.1 & 128.3 & 4 & PVC & s & $11 / 15 / 83$ & \\
\hline SRW 15A & Mw,PI & 104778 & 41234.7 & 3687356.43 & 429096.2 & 107.6 & 97.8 & 317.4 & 319.1 & 319.3 & 221.3 & 4 & $\overline{P V C}$ & 5 & $10 / 2 / 83$ & \\
\hline SRW 15B & Mw,PI & 104772.9 & 41252.5 & 3687358.61 & 429100.87 & 161.6 & 151.8 & 317.1 & 319.1 & 319.3 & 167.3 & 4 & PVC & s & $11 / 12 / 83$ & \\
\hline SRW 15C & $M w, P \mid$ & 104774.9 & 41245.1 & 3687357.52 & 429099 & 217.3 & 187.7 & 317.3 & 319.1 & 319.2 & 131.4 & 4 & PVC & is & $10 / 18 / 83$ & \\
\hline SRW 16A & $\mathrm{Mw}, \mathrm{PI}$ & 103763.4 & 42830.9 & 3687392.16 & 429670.77 & 144.1 & 119.4 & 344.5 & 346.8 & 346.9 & 227.4 & 4 & PVC & s & $\begin{array}{l}10 / 28 / 83 \\
\end{array}$ & \\
\hline SRW 16B & Mw,PI & 103772 & 42825.8 & 3687393.29 & 429667.99 & 169.9 & 160.1 & 344.4 & 346.8 & 346.9 & 186.7 & 4 & PVC & 5 & $11 / 13 / 83$ & \\
\hline SRW $16 \mathrm{C}$ & $\mid \mathrm{Mw}, \mathrm{PI}$ & 103772.4 & 42841.8 & 3687396.59 & 429672.67 & 235.7 & 205.7 & 345.3 & 346.6 & 346.8 & 140.9 & 4 & PVC & $s$ & $7 / 4 / 84$ & \\
\hline SRW 17BB & $M w, P \mid$ & 103956.1 & 42463.8 & 3687374.22 & 429545.91 & 132.3 & 122.2 & 331.3 & 333.4 & 333.6 & 211.2 & 4 & PVC & S & $9 / 2 / 93$ & \\
\hline SRW 17C & Mw,PI & 103965.9 & 42465.5 & 3687376.45 & 429545 & 161.3 & 151.2 & 331.3 & 333.6 & 334 & 182.4 & 2 & PVC & IV & 9/13/93 & \\
\hline SRW $17 D$ & $M w, P \mid$ & 103975.9 & 42468.7 & 3687379.78 & 429544,09 & 220.4 & 200.4 & 331.4 & 333.7 & 334 & 133.3 & 2 & PVC & v & $9 / 3 / 93$ & \\
\hline UNK 7 & & 101987 & 46250 & 3687567.87 & 430831.82 & & & & & & & & Steel & & & \\
\hline & & & & & & & & & & & & & & & & \\
\hline \multicolumn{17}{|l|}{ NOTES } \\
\hline & & & & & & & & & & & & & & & & \\
\hline \multirow{2}{*}{\multicolumn{17}{|c|}{$\begin{array}{l}\text { WELL TYPES: Mw - monitor well; Sp - special Well; PI - plume definition well; PZ - pl } \\
\text { SRSN and SRS E - Well coordinates in the SRS surveying system }\end{array}$}} \\
\hline & & & & & 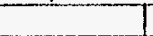 & & & & & & & & & & & \\
\hline \\
\hline \multicolumn{17}{|c|}{ SZT - Elevation of the top of the screen zone; SZ B - Elevation of the bottom of the screen zone } \\
\hline \multirow{2}{*}{\multicolumn{17}{|c|}{$\begin{array}{l}\text { GRND - Land surface elevation, in ft. above msl. } \\
\text { TOC. Top of casing elevation in } \mathrm{ft} \text { above } \mathrm{msl} \text {. }\end{array}$}} \\
\hline & & & & & & & & & & & & & & & & \\
\hline \multicolumn{17}{|c|}{$\frac{\text { IOC - Top of casing elevation, in } \mathrm{n} \text {. above msl. }}{\text { TOS - Top of standpipe elevation, in ftl above msl. }}$} \\
\hline \multicolumn{17}{|c|}{ EWD - efective well delph (ft) } \\
\hline \multicolumn{17}{|c|}{$C$ DIA - casing diameter } \\
\hline CASING $\cdot m$ & aterial, PI & Ivinyl chloride & stainless $\mathrm{s}$ & $e l_{1} C S=$ carbon & eel & & & & & & & & & & & \\
\hline \multirow{2}{*}{\multicolumn{17}{|c|}{$\begin{array}{l}\text { PUMP - pump type, } S=\text { single speed, } B \text { - bailer, } P \text { - bladder pump, } V \text { - variable speed } \\
\text { IINSTALL - date of installation }\end{array}$}} \\
\hline & & & & & & & & & & & & & & & & \\
\hline & ABAND & te abandone & bandoned) & & & & & & & & & & & & & \\
\hline
\end{tabular}


Table B. List of wells in the monitoring program 


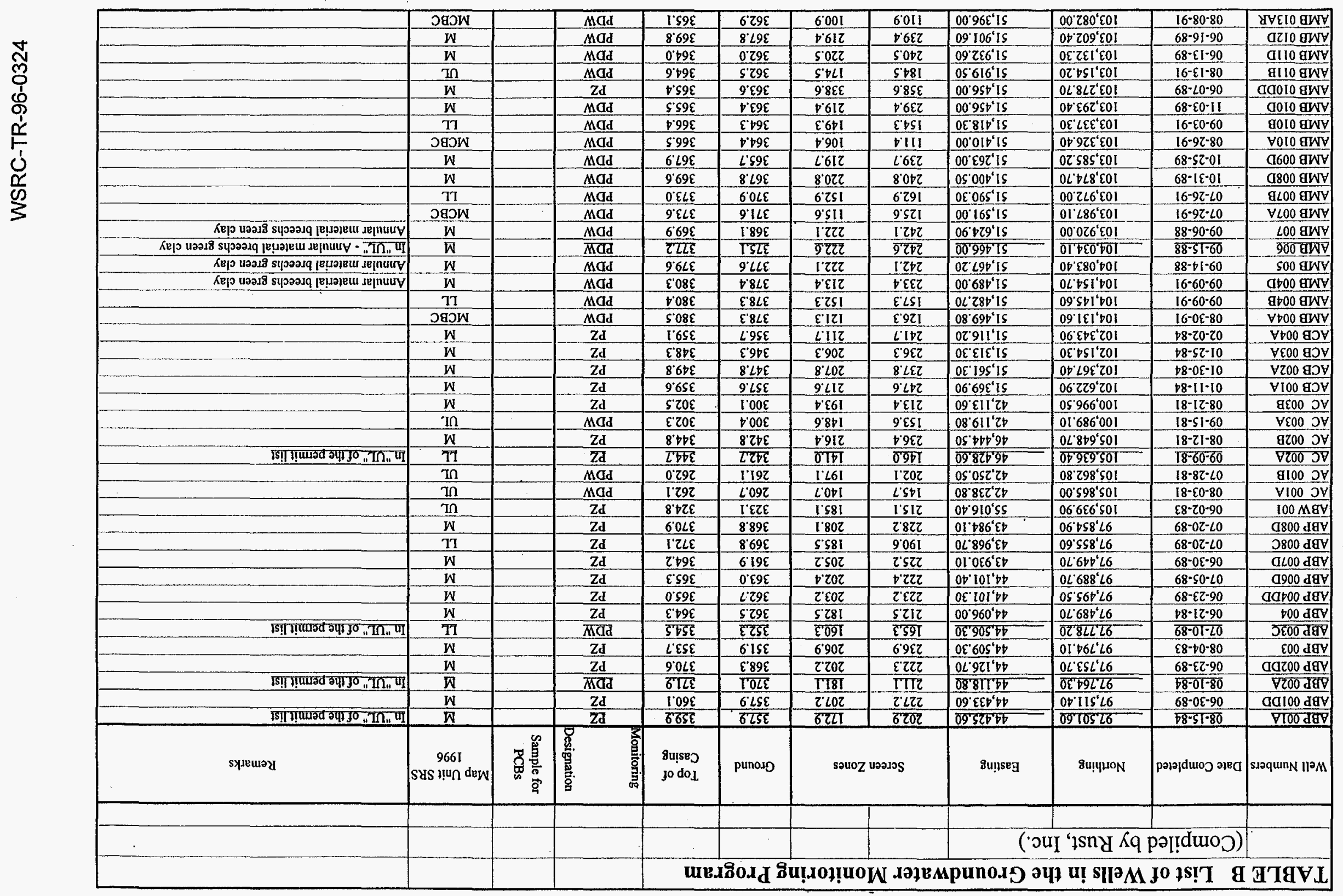




\begin{tabular}{|c|c|c|c|c|c|c|c|c|c|c|c|}
\hline AMB 014D & $09-07-90$ & $104,278.73$ & $51,360.78$ & 235.1 & 215.1 & 380.1 & 382.4 & PDW & & $\bar{M}$ & \\
\hline $\mathrm{AMB} 015 \mathrm{D}$ & $09-05-90$ & $104,500.55$ & $51,383.81$ & 236.2 & 216.2 & 381.2 & 383.4 & PDW & & M & \\
\hline AMB $016 \mathrm{D}$ & $08-08-90$ & $104,268.77$ & $51,557,53$ & 233.4 & 213.4 & 378.4 & 380.4 & PDW & & $\bar{M}$ & \\
\hline AMB 017A & $08-29-90$ & $104,056.74$ & $51,465.37$ & 125.0 & 120.0 & 377.0 & 379.1 & PDW & & MCBC & \\
\hline AMB $018 \mathrm{~A}$ & $07-27.90$ & $103,988.75$ & $51,418.79$ & 136.4 & 131.4 & 375.4 & 377.3 & PDW & & $\overline{M C B C}$ & \\
\hline $\mathrm{AMB} 018 \mathrm{C}$ & 08-02-90 & $103,983.38$ & $51,432.77$ & .214 .2 & 209.2 & 374.2 & 376.0 & PDW & & UL & \\
\hline $\mathrm{AMB} 019 \mathrm{C}$ & $07.17-90$ & $102,941.12$ & $51,503.74$ & 196.7 & 191.7 & 361.7 & 363.7 & PDW & & $\mathrm{UL}$ & \\
\hline$\overline{\mathrm{AOB} 001}$ & $05-27-83$ & $101,910.70$ & $50,485,90$ & 248.5 & 218.5 & 338.5 & 341.1 & $\overline{\mathrm{PDW}}$ & & $M$ & \\
\hline$\widehat{\mathrm{AOB} 002}$ & $05-27-83$ & $102,009,80$ & $50,724.70$ & 250.2 & 220.2 & 343.2 & 345.4 & PDW & & $\bar{M}$ & \\
\hline$\overline{\mathrm{AOB}} 003$ & $04-21-89$ & $102,164,40$ & $50,959.40$ & 243.9 & 223.9 & 350.6 & 352.6 & $\mathbf{P Z}$ & & $\mathrm{M}$ & \\
\hline$\overline{A R P \text { 001A }}$ & 02.03 .84 & $99,102.90$ & $44,317,40$ & 223.0 & 193.0 & 353.0 & 355.1 & $\mathbf{P Z}$ & & UL & \\
\hline ARP 002 & $12-22-83$ & $99,119.80$ & $44,876.10$ & 220.3 & 190.3 & 335.3 & 337.3 & $\mathrm{PZ}$ & & $\bar{M}$ & \\
\hline ARP 003 & $12-14-83$ & $98,638,20$ & $44,903.70$ & 218.2 & 188.2 & 338.2 & 339.8 & $\mathbf{P Z}$ & & $\overline{U L}$ & \\
\hline$\widehat{\text { ARP } 004}$ & $06-25-84$ & $98,567,70$ & $44,374.80$ & 227.8 & 197.8 & 346.8 & 348.4 & $\overline{\mathrm{PZ}}$ & & UL & \\
\hline ARP 005D & 03.02 .91 & $98,967.70$ & $44,530.00$ & $=$ & - & 347.3 & 350.5 & CRC & & $\mathrm{M}$ & \\
\hline ARP 008D & $08-07-90$ & $98,786.60$ & $44,132.60$ & 224.3 & 204.3 & 352.3 & 355.7 & $\mathrm{PZ}$ & & $\mathrm{M}$ & No measurements $1.4 Q 95$ \\
\hline ARP 009D & $08-08-90$ & $99,295.50$ & $44,686.60$ & 232.3 & 212.3 & 344.3 & 347.4 & $\overline{\mathrm{PZ}}$ & & $\mathrm{M}$ & No measurements 1-4Q95 \\
\hline ARP OIOD & $08-11-90$ & $98,536,50$ & $45,016.40$ & 239.3 & 219.3 & 333.5 & 336.2 & $\mathbf{P Z}$ & & $\mathbf{M}$ & No measurements $1.4 Q 95$ \\
\hline ARP011D & $08-16-90$ & $98,788.35$ & $45,081.10$ & 223.3 & 303.9 & 334.1 & 336.6 & $\mathbf{P Z}$ & & $\bar{M}$ & No measurements $1-4 Q 95$ \\
\hline ASB 001A & $01-05-84$ & $105,535.00$ & $52,614.00$ & 247.2 & 217.2 & 347.2 & 349.1 & PDW & & $\bar{M}$ & \\
\hline ASB 002A & & & & & & & & $\mathbf{P Z}$ & & M & No measurements $1-4 Q 95$ \\
\hline$\overline{A S B} 002 \mathrm{AR}$ & $02-12-93$ & $105,550.50$ & $52,881.70$ & 240.1 & 220.2 & 353.1 & 355.6 & PDW & & $\bar{M}$ & \\
\hline$\overline{\mathrm{ASB} \mathrm{002C}}$ & & & & & & & & $\overline{P Z}$ & & UL & No measurements 1-4Q95 \\
\hline ASB $002 C R$ & $01-04-93$ & $105,540.20$ & $52,862.70$ & 183.1 & 173.1 & 353.1 & 355.6 & PDW & & $\overline{\mathbf{L L}}$ & \\
\hline$\overline{\mathrm{ASB} 003 \mathrm{~A}}$ & & & & & & & & $\overline{\mathbf{P Z}}$ & & $\mathrm{M}$ & No measurements 1-4Q95 \\
\hline ASB 003AR & $01-22-93$ & $105,605.10$ & $53,115.00$ & 243.1 & 223.1 & 339.1 & 341.6 & PDW & & $\bar{M}$ & \\
\hline$\overline{\mathrm{ASB}} 003 \mathrm{C}$ & & & & & & & & $\mathbf{P Z}$ & & UL & No measurements 1-4Q95 \\
\hline ASB $003 \mathrm{CR}$ & 01.22 .93 & $105,614.50$ & $53,130.40$ & 18.4 .0 & 174.0 & 339.0 & 341.5 & PDW & & LL & \\
\hline ASB 004 & $08-20-81$ & $105,935.70$ & $53,177.20$ & 256.1 & 226.1 & 333.1 & 335.6 & PDW & & $\bar{M}$ & \\
\hline$\overline{\mathrm{ASB}} \overline{005 \mathrm{~A}}$ & & & & & & & & $\mathbf{P Z}$ & & $\mathrm{M}$ & No measurements $1-4 Q 95$ \\
\hline ĀSB 005AR & $02-01-93$ & $105,900.50$ & $52,854.40$ & 243.8 & 223.8 & 344.5 & 347.0 & PDW & & $\bar{M}$ & \\
\hline$\overline{\mathrm{ASB}} \mathbf{0 0 5 \mathrm { C }}$ & $01-19-93$ & $105,884,80$ & $52,837.80$ & 175.1 & 165.1 & 344.8 & 347.3 & PDW & & $\mathbf{L L}$ & \\
\hline ASB 006A & $02-20-84$ & $105,716.00$ & $52,675.90$ & 248.2 & 218.2 & 348.2 & 350.2 & PDW & & $\bar{M}$ & \\
\hline$\overline{\mathrm{ASB}} 006 \mathrm{AA}$ & $12-09-88$ & $105,727.00$ & $52,643.90$ & 82.8 & 78.1 & 351.8 & 354.2 & PDW & & MCBC & \\
\hline ASB 006C & $12-21-90$ & $105,736,80$ & 52.655 .90 & 178.5 & 173.8 & 351.5 & 353.6 & PDW & & $\mathbf{L L}$ & In "UL" of the permit list \\
\hline$\overline{\mathrm{ASB} \text { 006TA }}$ & $01-30-91$ & $105,749.50$ & $52,671,30$ & 40.0 & 34.5 & 351.0 & 352.9 & PDW & & $\mathrm{CBA}$ & \\
\hline ASB 007 & & & & & & & & $\mathrm{PZ}$ & & $\mathrm{M}$ & No measurements $1-4 \mathrm{Q} 95$ \\
\hline$\overline{\mathrm{ASB}} 008$ & & $106,381.60$ & $53,136.60$ & 226.6 & 206.6 & & 349.0 & PDW & & UL & Sampled 3Q95. Not on well list $3 / 13 / 95$. \\
\hline$\overline{A S B} 008 A$ & $03-26-85$ & $106,369 . \overline{30}$ & $53,117.50$ & 83.5 & 77.9 & 347.2 & 349.3 & $\overline{\mathrm{PZ}}$ & & $\mathrm{MCBC}$ & \\
\hline ASB 008B & $12-14-84$ & $106,362,30$ & 53.109 .60 & 128,4 & 122.8 & 347.6 & 342.8 & PDW & & MCBC & In "LL" of the permit list \\
\hline ASB 008C & $12 \cdot 18 \cdot 84$ & $106,354.40$ & $53,101.00$ & 188.3 & 182.7 & 347.6 & 349.7 & PDW & & $\overline{\mathrm{UL}}$ & \\
\hline ASB 008D & .. & $106,381.60$ & $53,136.60$ & 226.6 & 206.6 & 346.6 & 349.0 & $\mathrm{PZ}$ & & $\mathrm{M}$ & No measurements $1.4 \mathrm{Q} 95$ \\
\hline ASB 008TA & $10-17-84$ & $106,375.80$ & $53,124.70$ & 24.6 & 19.4 & 347.3 & 349.6 & $\overline{P D W}$ & & $\mathrm{CBA}$ & \\
\hline$\widehat{A S B} 009$ & . & $104,589.20$ & $54,226.20$ & 236.4 & 216.4 & 306.4 & 309.0 & $\mathrm{PZ}$ & & $M$ & Remote and isolated flags (suspect) \\
\hline ASB 009B & $07-16 \cdot 87$ & $104,564.70$ & $54,215,30$ & 164.4 & 158.8 & 306.6 & 309.0 & PDW & & $\overline{\mathrm{LL}}$ & \\
\hline ASB 009C & 02.16 .89 & $104,568.10$ & $54,201.10$ & 182.9 & 178.2 & 307.9 & 309.9 & PDW & & UL & \\
\hline ASB 010C & & & & & & & & $\mathrm{PZ}$ & & $\mathrm{UL}$ & No measurements $1-4 \mathrm{Q} 95$ \\
\hline ASB 010CR & 02.01 .93 & $105,655 . \overline{40}$ & $52,969.70$ & 181.7 & 171.7 & 346.7 & 349.2 & PDW & & $\mathbf{L L}$ & \\
\hline $\mathrm{MCB} 002$ & $04-13-87$ & $97,012.60$ & $45,129.00$ & 225.9 & 205.9 & 326.1 & 328.4 & $\overline{\mathrm{PZ}}$ & & $\mathbf{M}$ & \\
\hline$\overline{\mathrm{MCB}} 004$ & $04-02-87$ & $97,532.50$ & $44,705.10$ & 229.6 & 208.6 & 348.2 & 350.4 & PZ & & $\mathbf{M}$ & \\
\hline
\end{tabular}




\begin{tabular}{|c|c|c|c|c|c|c|c|c|c|c|c|}
\hline MCB 005 & $04-14-87$ & $97,335.60$ & $44,863.90$ & 226.3 & 206.3 & 337.7 & 339.6 & $\mathrm{PZ}$ & & $\mathrm{M}$ & \\
\hline MCB 005C & $07-10-89$ & $97,315.10$ & $44,862.80$ & 161.2 & 156.2 & 337.2 & 339.1 & PDW & & $\mathrm{UL}$ & \\
\hline MCB 006 & $08-10-87$ & $97,425.70$ & $45,214,00$ & 219.7 & 199.7 & 329.9 & 332.1 & $\mathbf{P Z}$ & & $\bar{M}$ & \\
\hline $\mathrm{MCB} 006 \mathrm{C}$ & $06-21-89$ & $97,413.10$ & $45,207.70$ & 170.0 & 165.0 & 330.0 & 332.1 & PDW & & $\mathrm{UL}$ & \\
\hline $\mathrm{MCB} 007 \mathrm{C}$ & $07-17-89$ & $97,139.90$ & $44,870.60$ & 160.7 & 155.7 & 335.7 & 337.7 & PDW & & UL & \\
\hline MCB 008D & $07-07-89$ & $97,180.60$ & $44,769.90$ & 225.7 & 205.7 & 337.4 & 340.7 & $\mathrm{PZ}$ & & $\mathbf{M}$ & \\
\hline MCB 009D & 07.07 .89 & $97,605.80$ & $44,858.80$ & 226.2 & 206.2 & 339.1 & 342.9 & $\mathrm{PZ}$ & & $\bar{M}$ & \\
\hline MCB OLODR & $04-24-92$ & & & & & & & PDW & & & \\
\hline $\mathrm{MCB}$ 011B & $02-11-92$ & 96361,60 & 45392.10 & 110.1 & 105.1 & 300.1 & 302.2 & CRC & & & \\
\hline $\mathrm{MCB} 011 \mathrm{C}$ & $02-12-92$ & 96373.70 & 45383,60 & 146.1 & 141.1 & 300.1 & 302.3 & CRC & & & \\
\hline MCB 011D & $02-12-92$ & 96385.70 & 45374.90 & 230.3 & 210.3 & 300.3 & 302.4 & CRC & & & \\
\hline MCB 012B & $02-21-92$ & 98326.20 & 45246.10 & 137.7 & 132.7 & 325.7 & 327.7 & CRC & & & \\
\hline MCB 012C & $02-26-92$ & 98337.70 & 45236.60 & 162.0 & 157.0 & 326.0 & 328.2 & CRC & & & \\
\hline MCB $013 \mathrm{C}$ & $03-11-92$ & 96353.40 & 43950.40 & 166.8 & 161.8 & 354.8 & 356.9 & CRC & & & \\
\hline MCB 013D & $03-11-92$ & 96366,20 & 43958.90 & 235.0 & 214.9 & 355.0 & 357.1 & CRC & & & \\
\hline MCB OI4B & $05-09.92$ & 93929.40 & 41744.60 & 131.8 & 126.8 & 304.8 & 307.2 & CRC & & & \\
\hline МСB 014C & $05-13-92$ & 93930.50 & 41759.70 & 148.2 & 143.2 & 305.2 & 307.5 & CRC & & & \\
\hline MSB 001A & $01-01-83$ & $101,833.70$ & $48,467,30$ & 253.2 & 223.2 & 352.2 & 353.2 & $\mathbf{P Z}$ & & M & Not on ' 96 permit. \\
\hline MSB 001B & $10-18-90$ & $101,833.00$ & $48,483.20$ & 142.6 & 137.9 & 352.6 & 354.8 & POC & & $\mathrm{LL}$ & \\
\hline MSB 001C & $08-07-90$ & $101,832.50$ & $48,512.70$ & 166.0 & 161.3 & 353.0 & 355.1 & POC & & $\mathrm{UL}$ & POC well \\
\hline $\mathrm{MSB} 001 \mathrm{CC}$ & $10-26-90$ & $101,832.50$ & $48,498.00$ & 192.5 & 187.8 & 352.9 & 354.9 & $\overline{P O C}$ & & UL & Duplicates $1 \mathrm{C}$ (IC is POC well) \\
\hline MSB 001D & $10-10-90$ & $101,833.40$ & $48,452.20$ & 229.8 & 210.4 & 352.8 & 354.8 & POC & $\mathrm{x}$ & $\mathbf{M}$ & \\
\hline MSB 002A & $01-01-83$ & $102,028.30$ & $48,746,40$ & 252.6 & 222.6 & 351.2 & 352.6 & PZ & & $\mathrm{M}$ & Not on 96 permit. \\
\hline MSB 002B & $08-30-90$ & $101,997.90$ & $48,748.20$ & 150.3 & 145.6 & 352.3 & 354.6 & POC & & $\mathrm{LL}$ & \\
\hline MSB 002C & $08 \cdot 30 \cdot 90$ & $101,982.50$ & $48,749.30$ & 194.7 & 190,0 & 352.7 & 354.7 & POC & & UL. & \\
\hline $\mathrm{MSB} 002 \mathrm{D}$ & $11-16-90$ & $102,014.00$ & $48,755.70$ & 230.1 & 210.7 & 351.7 & 353.8 & POC & $\bar{x}$ & $\mathrm{M}$ & \\
\hline MSB 003A & $01-01-83$ & $102,189,90$ & $48,553,70$ & 259.5 & 229.5 & 358.1 & 359.5 & $\mathbf{P Z}$ & & $\mathbf{M}$ & Not on '96 permit. \\
\hline MSB 0038 & $09-17-90$ & $102,191,70$ & $48,568.00$ & 145.8 & 141.1 & 358.8 & 361.0 & POC & & LL & \\
\hline MSB 003C & $09-20.90$ & $102,189.60$ & $48,538.50$ & 193.7 & 189.0 & 358.7 & 360.8 & POC & & UL & \\
\hline MSB 003D & $09-20-90$ & $102,188.60$ & $48,524,60$ & 230.7 & 211.2 & 358.7 & 360.2 & POC & $\mathrm{x}$ & M & POC well, replaces $3 A$ \\
\hline MSB 004A & $10-08-82$ & $101,933.40$ & $48,313.00$ & 254.8 & 224.8 & 352.9 & 354.8 & $\mathrm{PZ}$ & & $\mathbf{M}$ & Not on ' 96 permit. \\
\hline MSB 004B & $10.03-90$ & $101,978.30$ & $48,312.80$ & 143.1 & 138.4 & 353.1 & 355.3 & POC & & $\mathrm{LL}$ & \\
\hline$\overline{\mathrm{MSB}}$ 004C & $08-23-90$ & $101,963.20$ & $48,313,60$ & 168.1 & 163.3 & 353.1 & 355.2 & POC & & UL & \\
\hline MSB 004D & $09-28-90$ & $102,007.50$ & $48,311.70$ & 228.4 & 209.0 & 353.4 & 355.5 & POC & $\mathrm{x}$ & $\mathbf{M}$ & POC well, replaces $4 \mathrm{~A}$ \\
\hline MSB 005A & $10-25-82$ & $101,971.50$ & $46,998.70$ & 247.2 & 217.2 & 342.2 & 344.6 & POC & & $\mathbf{M}$ & TLDIS (see Jack Gray) \\
\hline MSB 005B & $05-25-90$ & $101,971.10$ & $46,983.60$ & 136.1 & 131.4 & 343.1 & 345.0 & POC & & $\mathrm{LL}$ & \\
\hline MSB 005C & $05-25-90$ & $101,970.40$ & $46,968.60$ & 188.1 & 183.4 & 343.1 & 345.2 & POC & & UL & \\
\hline MSB 006A & $10-01-82$ & $101,133,80$ & $46,319.90$ & 241.9 & 211.9 & 341.9 & 343.8 & POC & & $\mathbf{M}$ & Remote and no flags \\
\hline MSB 006B & 05.09 .90 & $101,148.50$ & $46,321.60$ & 129.8 & 125.1 & 341.8 & 343.9 & POC & & $\overline{\mathrm{LL}}$ & \\
\hline MSB 006C & $05 \cdot 10-90$ & $101,169.10$ & $46,324.10$ & 194.0 & 189.3 & 342.0 & 343.8 & POC & & $\overline{\mathbf{U L}}$ & \\
\hline$\overline{\mathrm{MSB} 007 \mathrm{~A}}$ & $10-01-82$ & $100,585.70$ & $46,726.10$ & 242.0 & 212.0 & 342.0 & 344.3 & POC & & $\mathbf{M}$ & Remote and isolated flags (suspect) \\
\hline$\overline{\mathrm{MSB}} \mathbf{0 0 7 \mathrm { B }}$ & $04-18-90$ & $100,597.60$ & $46,718.10$ & 147.5 & 142.7 & 342.1 & 344.1 & POC & & $\mathrm{LL}^{-}$ & \\
\hline MSB 007C & $04-18-90$ & $100,609.20$ & $46,709.10$ & 200.1 & 195.4 & 342.1 & 344.5 & POC & & $\mathrm{UL}$ & \\
\hline MSB 008A & $10-01-82$ & $100,815,10$ & $47,293.20$ & 242.4 & 212.4 & 342.4 & 344.2 & POC & & $\mathrm{M}$ & Fine Sand in well water \\
\hline$\overline{\mathrm{MSB}}$ 008B & $04-05-90$ & $100,805.80$ & $47,281.90$ & 150.8 & 146.1 & 341.8 & 343.9 & POC & & LL & \\
\hline MSB 008C & $04-18-90$ & $100,793.20$ & $47,264,60$ & 195.9 & 191.2 & 341.9 & 344.0 & $\overline{P O C}$ & & $\mathrm{UL}$ & \\
\hline MSB 009A & $07-28-81$ & $-102,236,70$ & 48.242 .50 & 144.2 & 139.2 & 357.2 & 359.1 & PDW & & $\underline{L L}$ & In "UL" of the permit list \\
\hline MSB 009B & 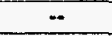 & $102,239.40$ & $48,251.70$ & 209.3 & 204.3 & 357.3 & 359.3 & $\mathbf{P Z}$ & & $\mathbf{U L}$ & \\
\hline $\mathrm{MSB} 009 \mathrm{C}$ & $12-18 \cdot 81$ & $102,245.60$ & $48,273,00$ & 241.6 & 221.6 & 357.6 & 359.6 & PDW & $\mathrm{x}$ & $\mathrm{M}$ & \\
\hline$\overline{\mathrm{MSB} 010 \mathrm{~A}}$ & $09-03-81$ & $102,451.80$ & $47,954.40$ & 125.2 & 120.2 & 355.2 & 357.2 & PDW & & MCBC & \\
\hline
\end{tabular}




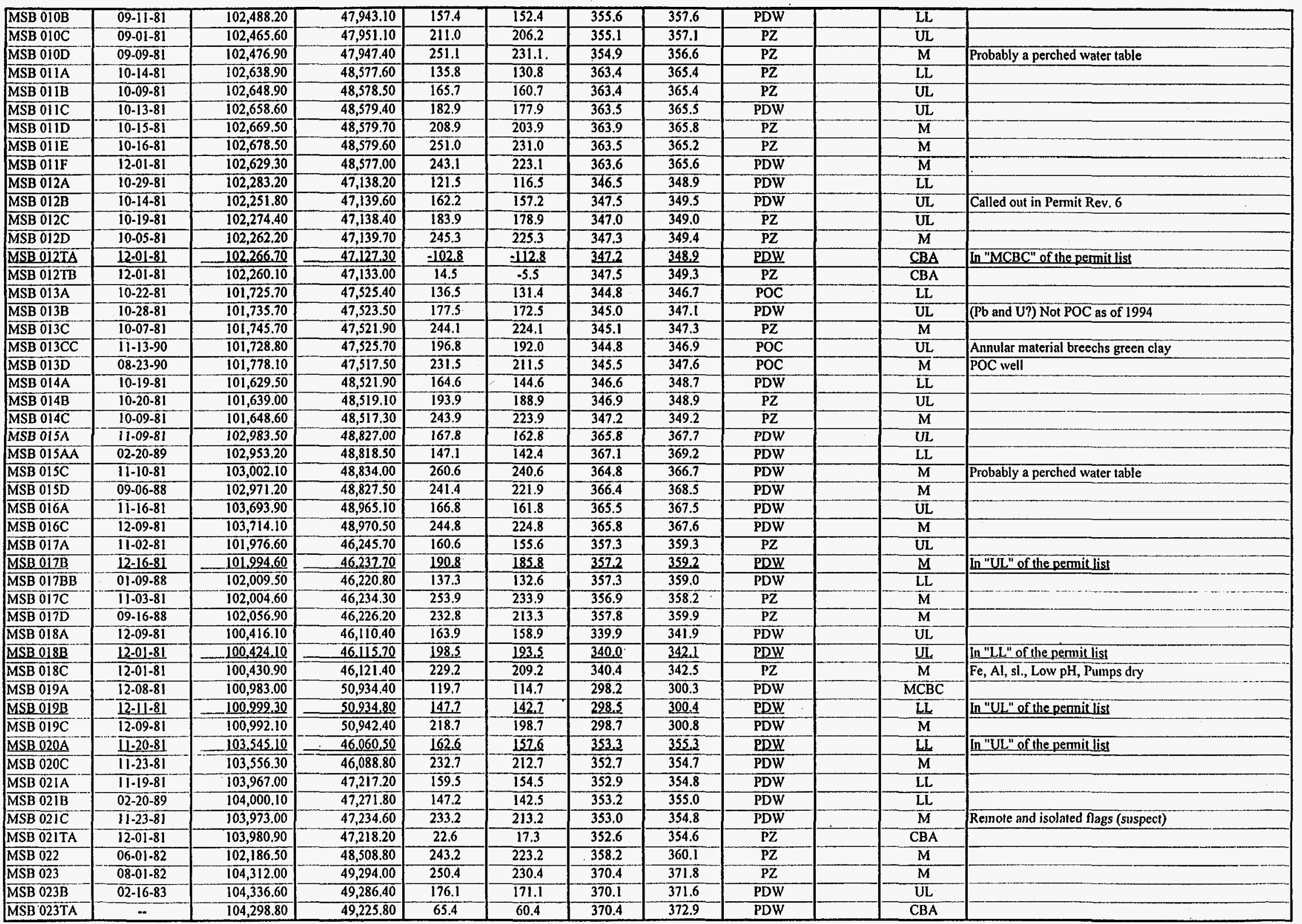




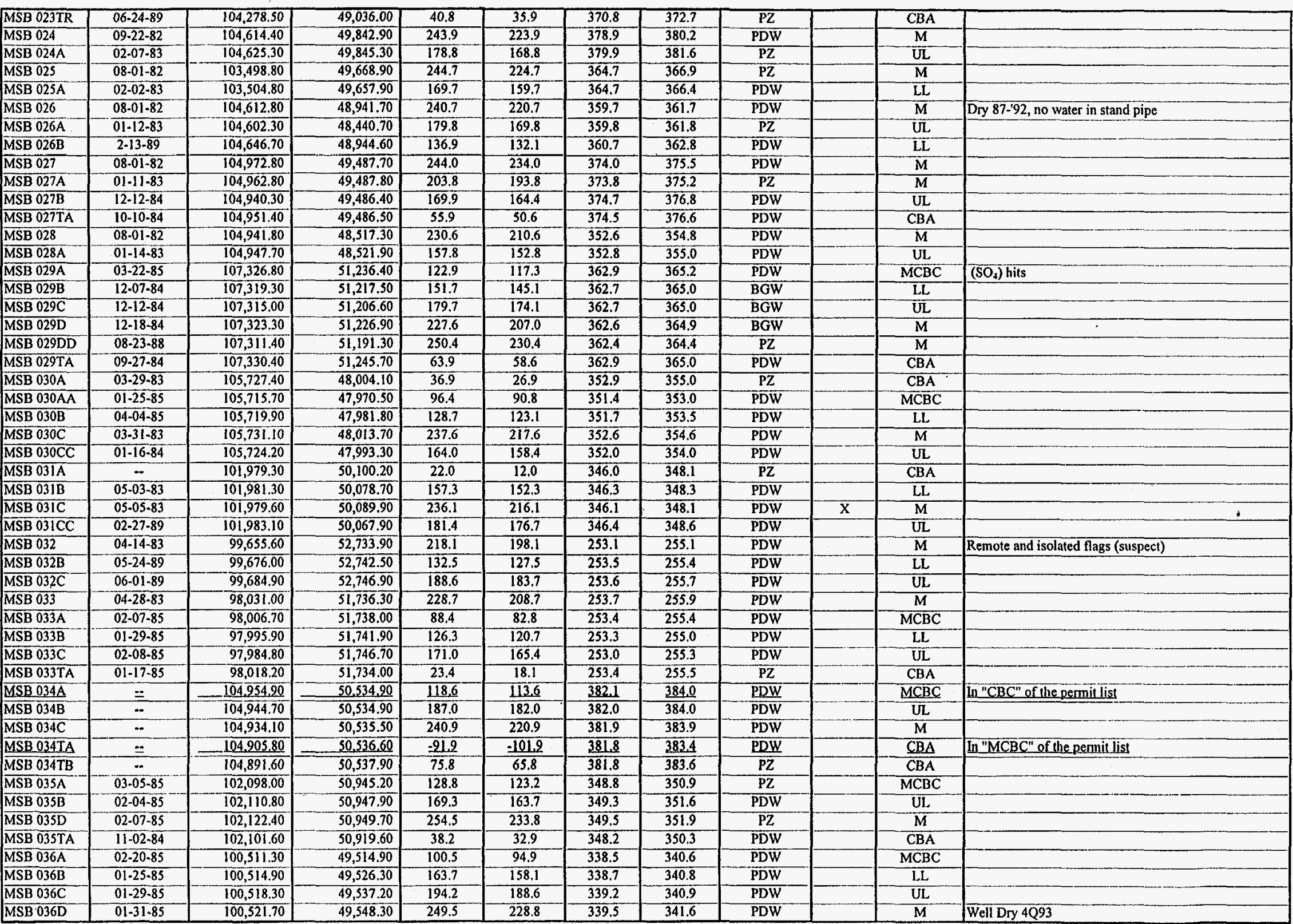




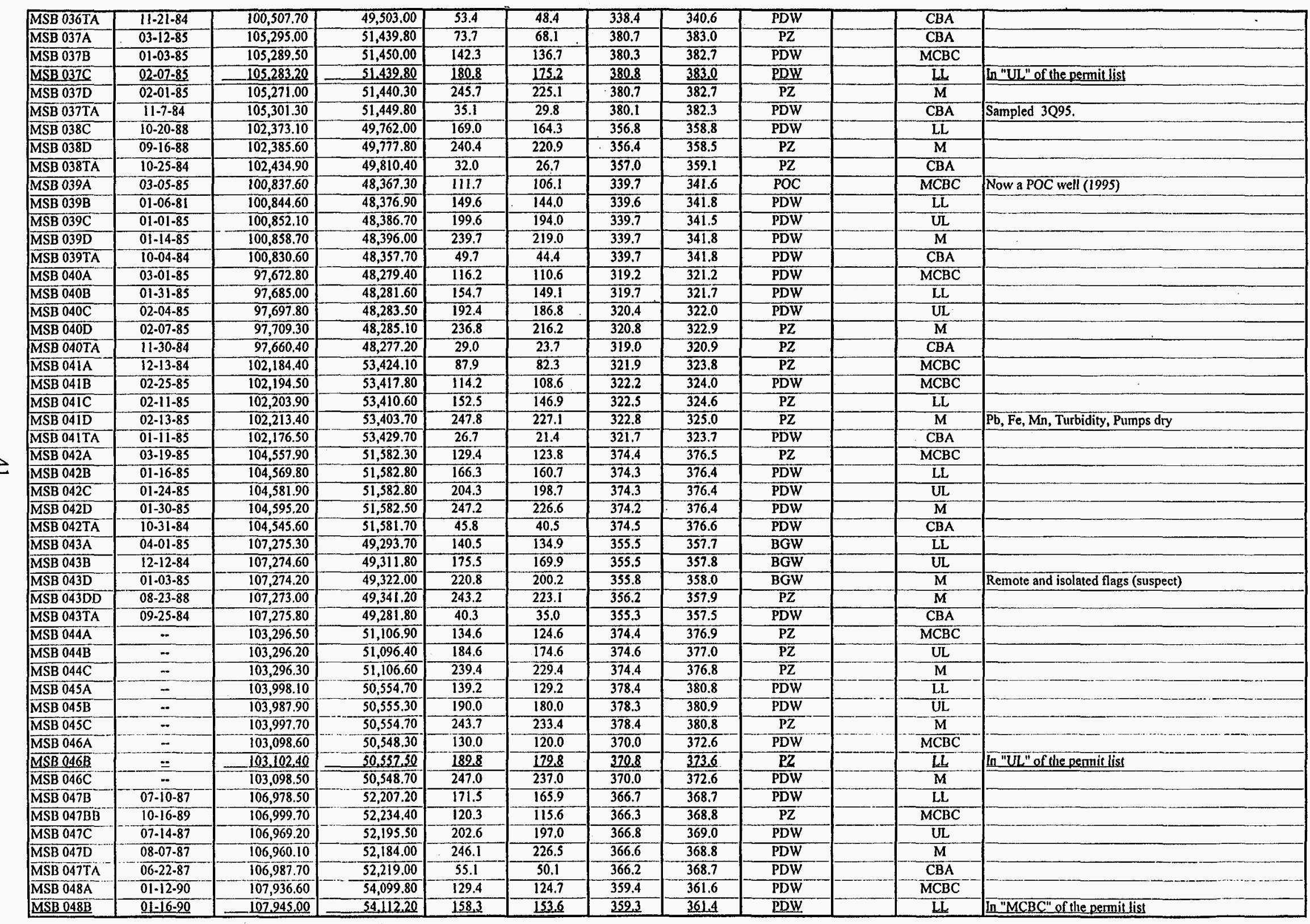




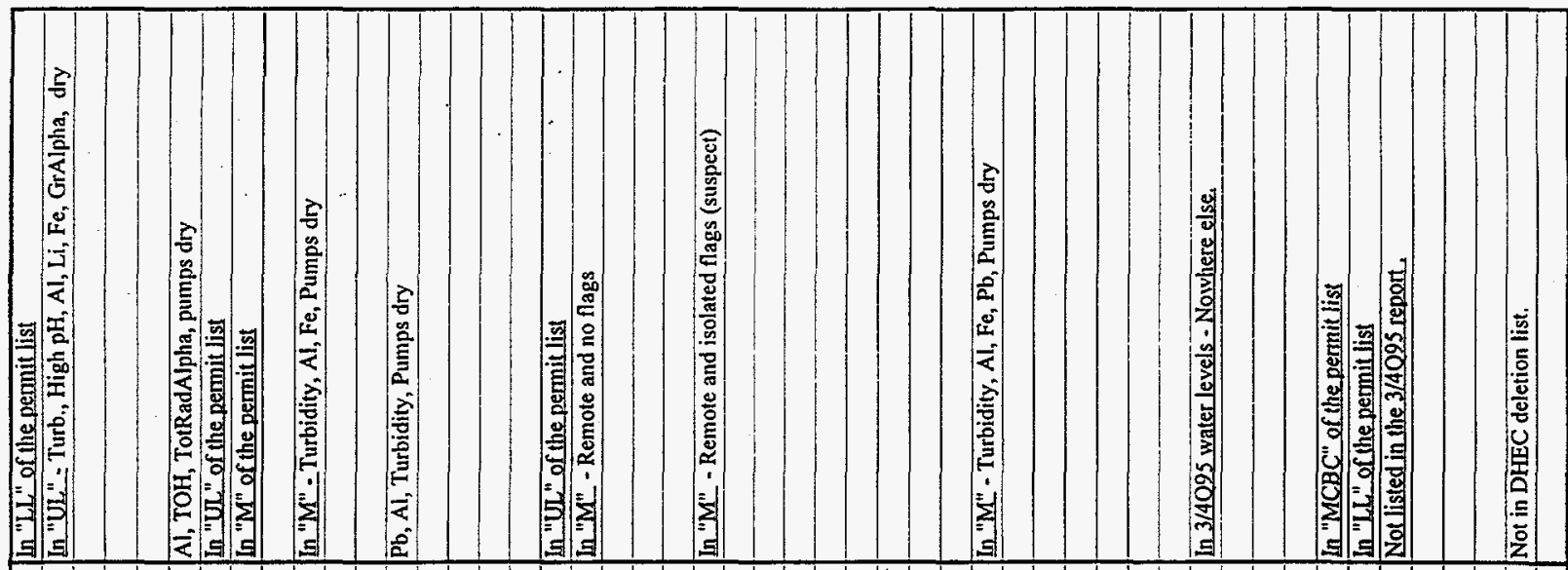

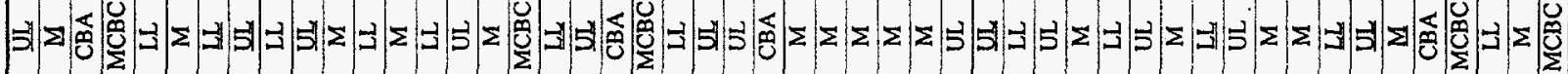
$x \times x \mid x$

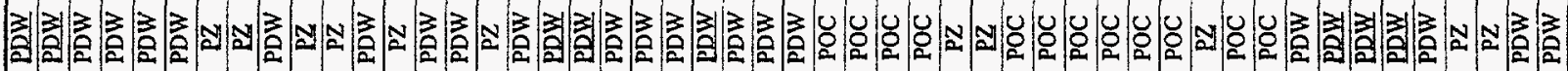

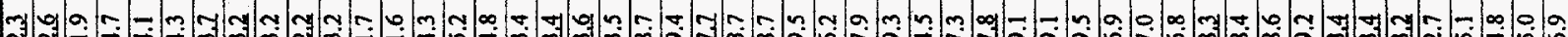

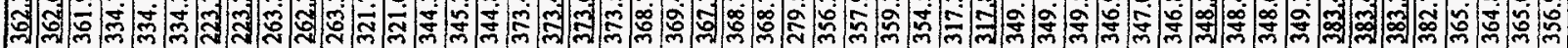

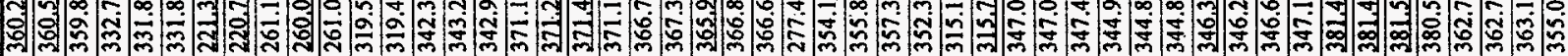

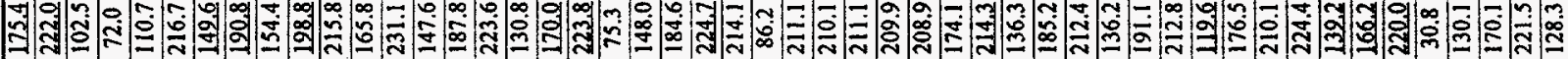

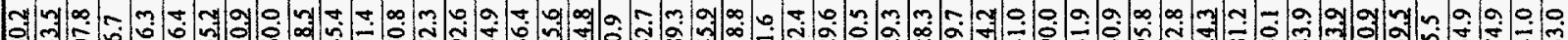

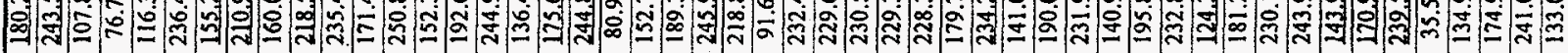

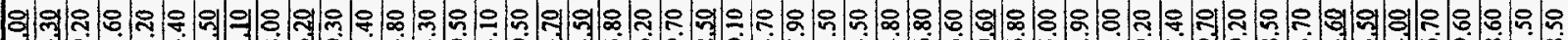
A जी

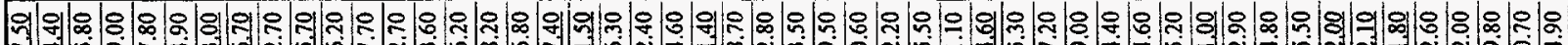

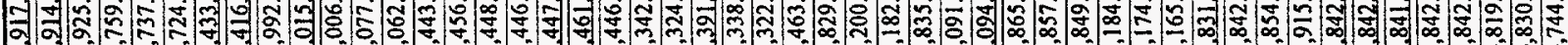
:

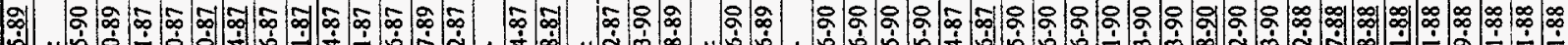

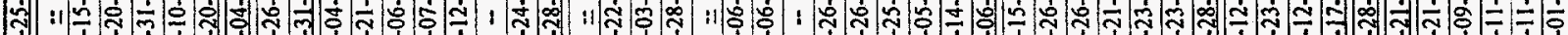
की

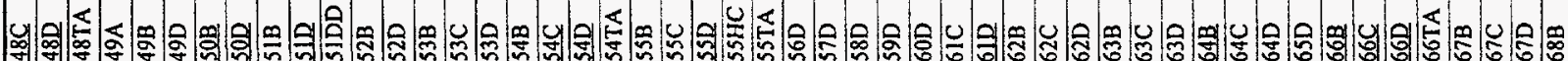

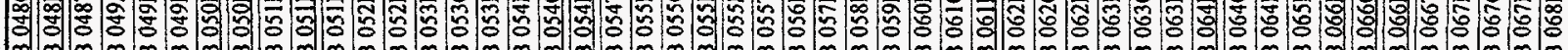

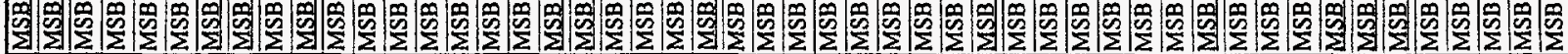




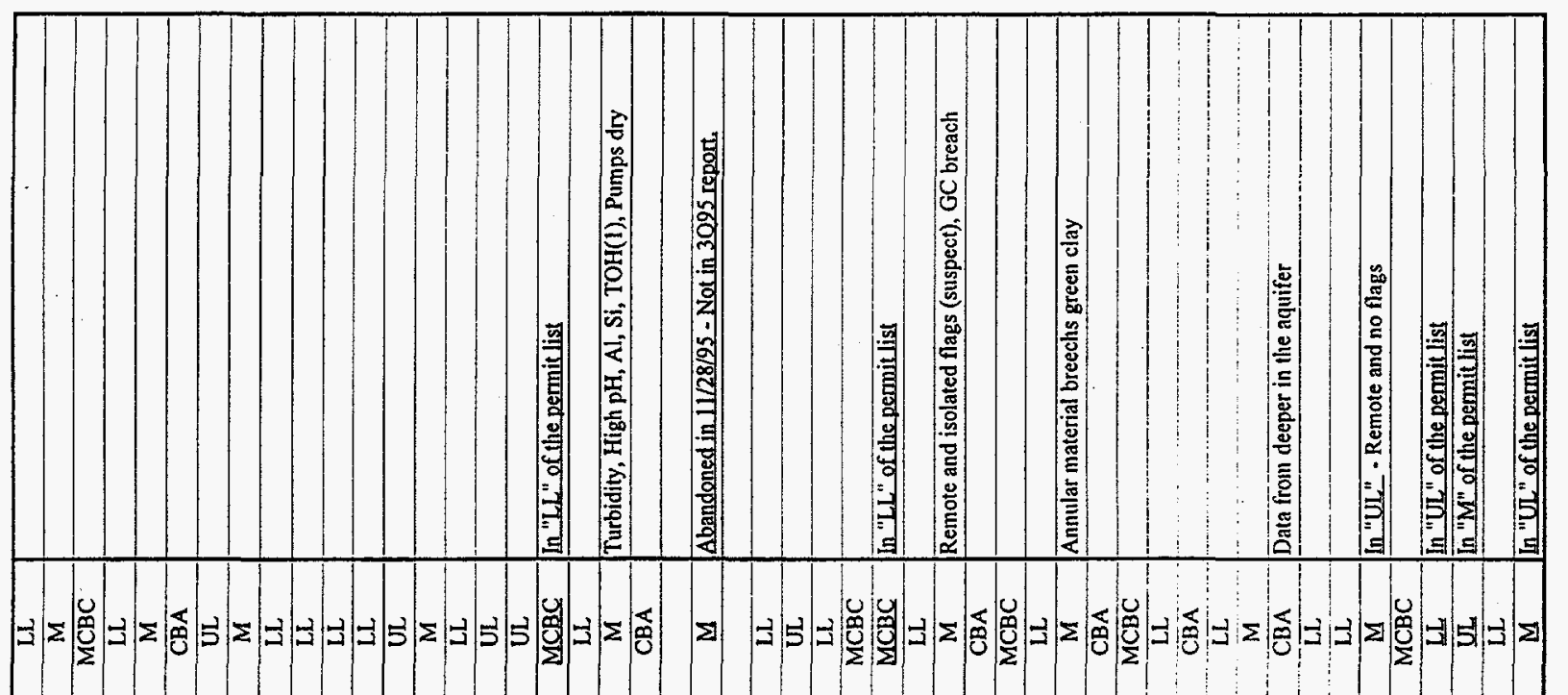

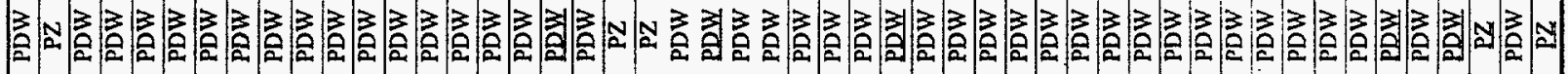

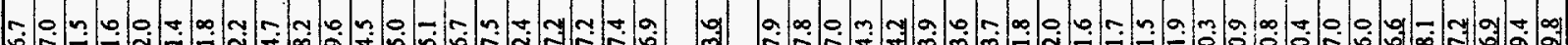

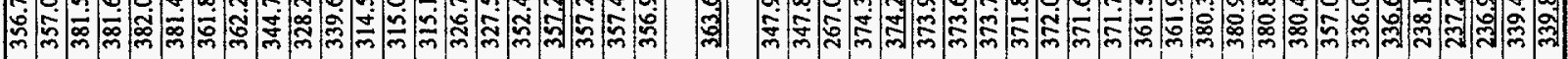

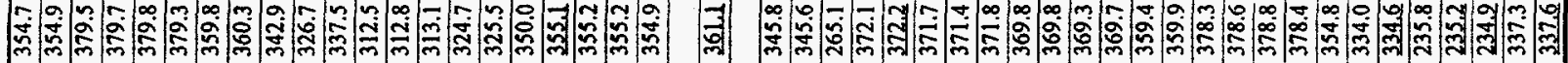

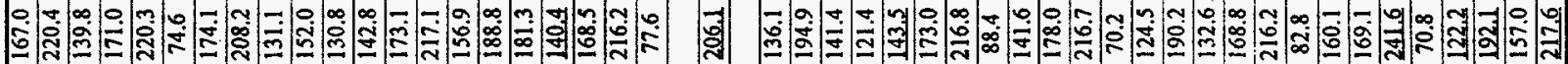

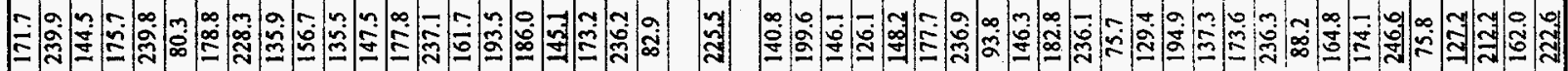

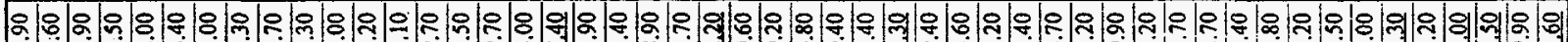

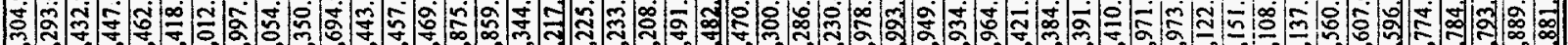

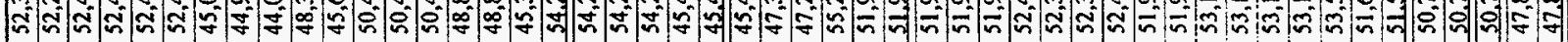

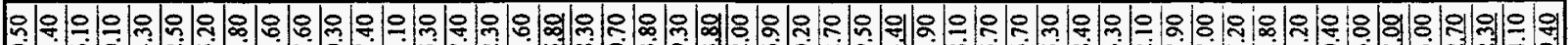

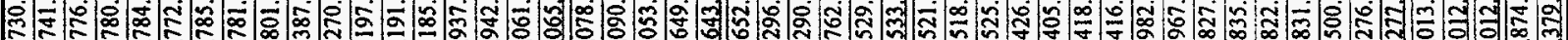
:-

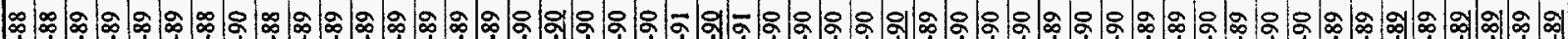

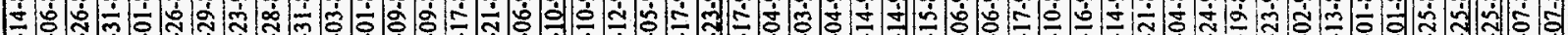

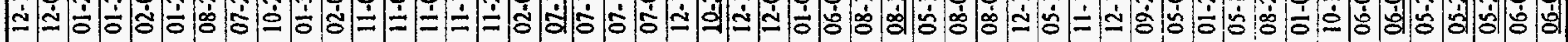

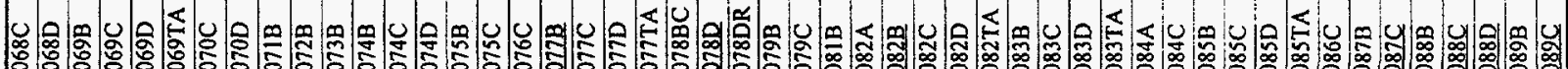

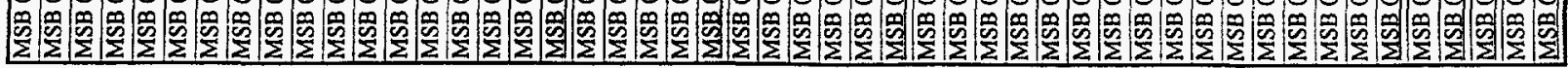




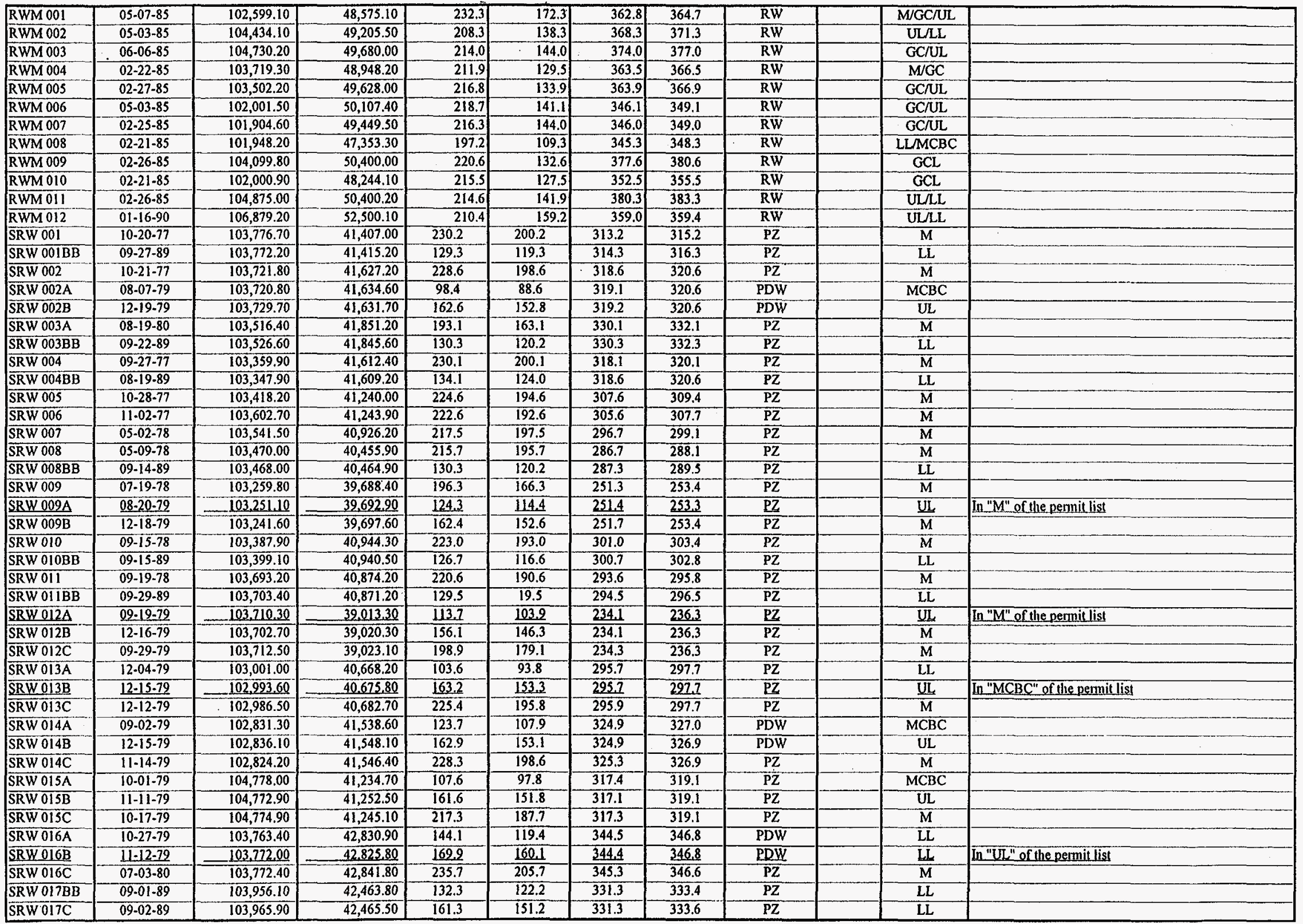




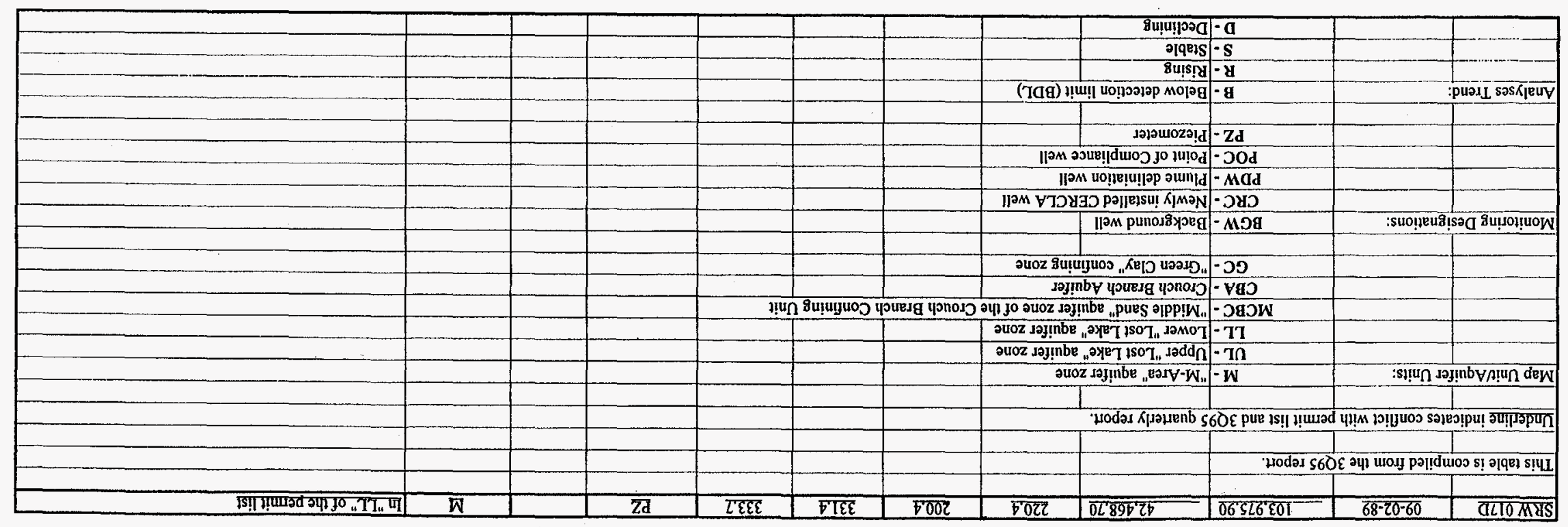


WSRC-TR-96-0324

Table C Partial List of Annular Material ARC/INFO coverage point attribute table (PAT) 


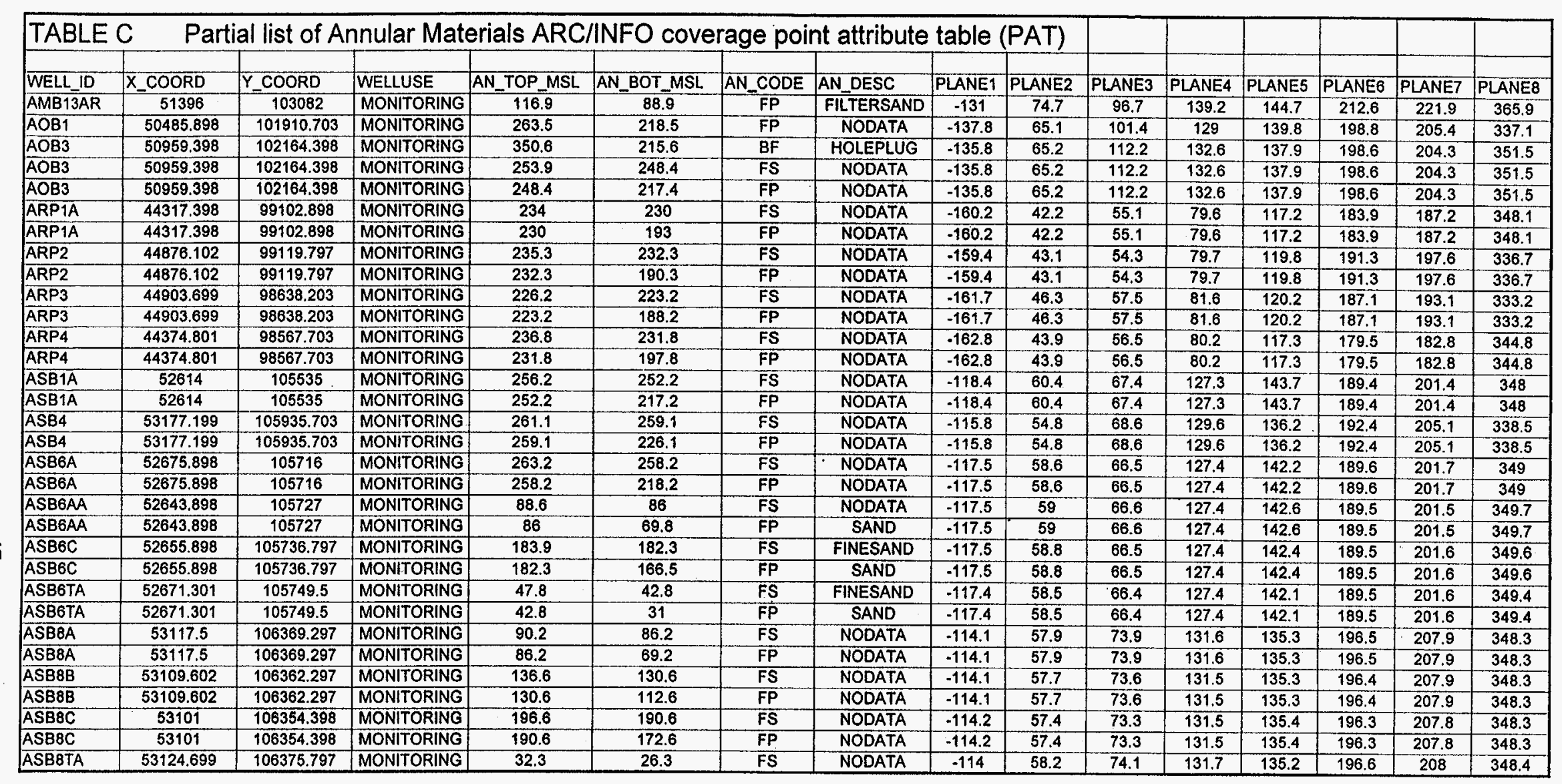




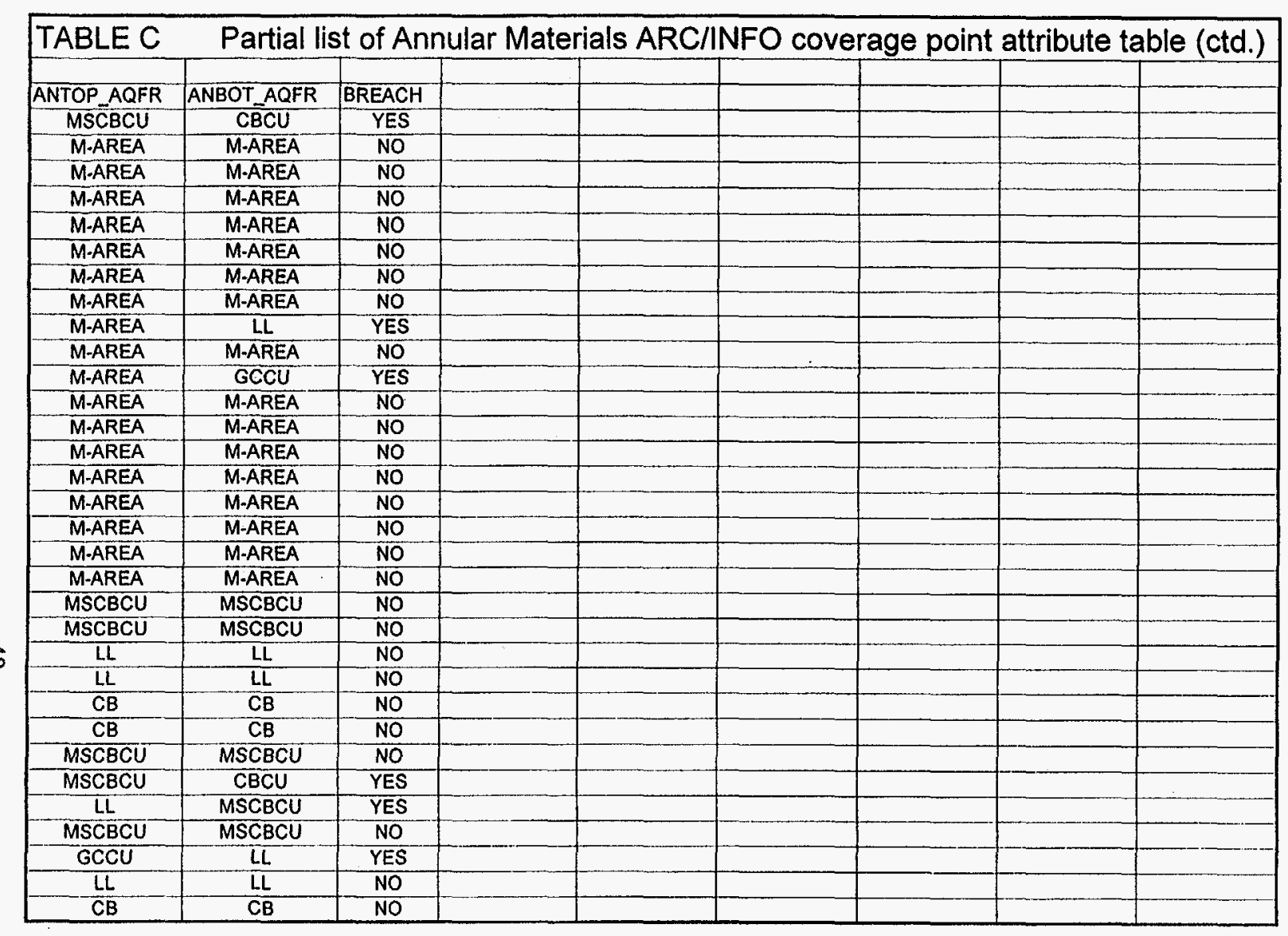


TABLE D Partial listing of Screen Zone ARC/INFO coverage point attribute table (PAT) 


\begin{tabular}{|c|c|c|c|c|c|c|c|c|c|c|c|c|c|c|c|}
\hline \multirow[t]{2}{*}{ TABLE D } & \multicolumn{11}{|c|}{ Partial listing of Screen Zone ARC/INFO coverage point attribute table (PAT) } & & & & \\
\hline & & & & & & & & & & & & & & & \\
\hline WELLNAME & TYPE1 & TYPE2 & SRS_N & SRS_E & SZ__TOP & SZ_BOT & GROUND & TOC & TOS & DEPTH & CASEDIA & CASEMATL & PUMP & INSTALL & ABANDON \\
\hline$\overline{A B P I A}$ & $\overline{M w}$ & PI & 97501.6 & 44425.6 & 202.9 & 172.9 & 357.9 & 359.9 & 360 & 187 & 4 & PVC & $S$ & $8 / 15 / 84$ & \\
\hline ABP1DD & $P_{2}$ & & 97511.4 & 44433.6 & 227.2 & 207.2 & 357.9 & 380.1 & 0 & 152.9 & 2 & PVC & & $6 / 30 / 89$ & \\
\hline ABP2A & $\mathrm{Mw}$ & PI & 97764.3 & 44118.8 & 211.1 & 181.1 & 370.1 & 371.9 & 372 & 190.8 & 4 & PVC & $S$ & $8 / 10 / 84$ & \\
\hline$A B P 2 D D$ & $\mathrm{Pz}_{2}$ & & 97753.7 & 44126.7 & 222.3 & 202.2 & 368.3 & 370.6 & 0 & 168.4 & 2 & PVC & & $6 / 23 / 89$ & \\
\hline$A B P 3$ & $M w$ & PI & 97794.1 & 44509.3 & 236.9 & 206.9 & 351.9 & 353.7 & 353.8 & 146.8 & 4 & PVC & $S$ & $8 / 4 / 83$ & \\
\hline ABP3C & $\mathrm{Mw}$ & $\mathrm{PI}$ & 97778.2 & 44506.3 & 165.3 & 160.3 & 352.3 & 354.5 & 354.8 & 194.2 & 4 & PVC & $S$ & $7 / 10 / 89$ & \\
\hline$\overline{\mathrm{ABP} 4}$ & $M w$ & PI & 97489.7 & 44096 & 212.5 & 182.5 & 362.5 & 364.3 & 364.5 & 181.8 & 4 & PVC & $\mathrm{s}$ & $6 / 21 / 84$ & \\
\hline ABP4DD & $\mathrm{Pz}$ & & 97495.5 & 44101.3 & 223.2 & 203.2 & 362.7 & 365 & 0 & 161.8 & 2 & PVC & & $6 / 23 / 89$ & \\
\hline ABPGD & $\mathrm{Pz}$ & & 97888.7 & 44101.4 & 222.4 & 202.4 & 363 & 365.3 & 0 & 162.9 & 2 & PVC & & $7 / 5 / 89$ & \\
\hline ABP7D & $\overline{P_{z}}$ & & 97449.7 & 43930.1 & 225.2 & 205.2 & 361.9 & 364.2 & 0 & 159 & 2 & PVC & & $6 / 30 / 89$ & \\
\hline$\overline{\mathrm{ABPBC}}$ & $\mathrm{Mw}$ & PI & 97855.6 & 43968.7 & 190.6 & 185.5 & 369.8 & 372.1 & 372.3 & 186.6 & 4 & PVC & S & $7 / 20 / 89$ & \\
\hline ABP8D & $\mathrm{Mw}$ & $\mathbf{P I}$ & 97854.9 & 43984.1 & 228.2 & 208.1 & 368.8 & 370.9 & 371.1 & 162.8 & 4 & PVC & $S$ & $7 / 20 / 89$ & \\
\hline$\overline{A B W 1}$ & $\mathrm{Mw}$ & PI & 105939.9 & 55016.4 & 215.1 & 185.1 & 323.1 & 324.8 & 325 & 139.7 & 4 & PVC & 5 & $6 / 2 / 83$ & \\
\hline$A C 1 A$ & $\mathrm{Mw}$ & $\mathrm{PI}$ & 105865 & 42238.8 & 145.7 & 140.7 & 260.7 & 262.1 & 262.4 & 121.4 & 4 & Steel & s & $8 / 3 / 81$ & \\
\hline AC18 & $\mathrm{Mw}$ & $\mathrm{PI}$ & 105862.8 & 42250.5 & 202.1 & 197.1 & 261.1 & 262 & 262.2 & 64.9 & 4 & Steel & $S$ & $7 / 28 / 81$ & \\
\hline$\overline{A C 2 A}$ & $\overline{M w}$ & $\mathrm{PI}$ & 105636.4 & 46428.6 & 146 & 141 & 342.7 & 344.7 & 344.9 & 203.7 & 4 & $\overline{P V C}$ & $S$ & $9 / 9 / 81$ & \\
\hline$A C 2 B$ & $\overline{M w}$ & $\mathrm{PI}$ & 105648.7 & 46444.5 & 236.4 & 216.4 & 342.8 & 344.8 & 345 & 128.4 & 4 & PVC & $s$ & $8 / 12 / 81$ & \\
\hline$A C 3 A$ & $\overline{M w}$ & $\mathrm{PI}$ & 100989.1 & 42119.8 & 153.6 & 148.6 & 300.4 & 302.3 & 302.5 & 153.7 & 4 & PVC & $\mathrm{S}$ & $9 / 15 / 81$ & \\
\hline$\overline{A C 3 B}$ & $M w$ & PI & 100996.5 & 42113.6 & 213.4 & 193.4 & 300.1 & 302.5 & 302.8 & 109.1 & 4 & PVC & $\mathbf{S}$ & $8 / 21 / 81$ & \\
\hline ACB1A & $\mathrm{Mw}$ & $\overline{\mathrm{PI}}$ & 102622.9 & 51369.9 & 247.6 & 217.6 & 357.6 & 359.6 & 359.7 & 142 & 4 & PVC & $s$ & $1 / 11 / 84$ & \\
\hline ACB2A & $\mathrm{Mw}$ & PI & 102367.4 & 51561.3 & 237.8 & 207.8 & 347.8 & 349.8 & 350 & 142 & 4 & PVC & $S$ & $1 / 30 / 84$ & \\
\hline$\overline{A C B 3 A}$ & $\mathrm{Mw}$ & PI & 102154.3 & 51313.3 & 236.3 & 206.3 & 346.3 & 348.3 & 349.5 & 142 & 4 & PVC & $\mathrm{S}$ & $1 / 25 / 84$ & \\
\hline ACB4A & $\overline{M w}$ & PI & 102343.9 & 51116.2 & 241.7 & 211.7 & 356.7 & 359.1 & 0 & 147.4 & 4 & PVC & $s$ & $2 / 2 / 84$ & \\
\hline$\overline{A M B 4 A}$ & $M w$ & $\mathrm{PI}$ & 104131.6 & 51469.8 & 126.3 & 121.3 & 378.3 & 380.5 & 380.7 & 259.2 & 4 & PVC & $\mathbf{S}$ & $8 / 30 / 91$ & \\
\hline AMB4B & $\overline{M w}$ & $\mathrm{PI}$ & 104145.6 & 51482.7 & 157.3 & 152.3 & 378.3 & 380.4 & 380.6 & 228.1 & 4 & PVC & $S$ & $9 / 9 / 91$ & \\
\hline AMB4D & Mw & $\mathrm{PI}$ & 104154.7 & 51489 & 233.4 & 213.4 & 378.4 & 380.3 & 0 & 166.9 & 4 & PVC & $S$ & $9 / 9 / 91$ & \\
\hline AMB5 & $M w$ & $\mathrm{PI}$ & 104083.4 & 51467.2 & 242.1 & 222.1 & 377.6 & 379.6 & 379.8 & 157.5 & 4 & PVC & $S$ & $9 / 14 / 88$ & \\
\hline$\overline{A M B} 6$ & $M w$ & PI & 104034.1 & 51466 & 242.6 & 222.6 & 375.1 & 377.2 & 377.4 & 154.6 & 4 & PVC & $S$ & $9 / 15 / 88$ & \\
\hline AMB7 & $\mathrm{Mw}$ & $\mathrm{PI}$ & 103920 & 51624.9 & 242.1 & 222.1 & 368.1 & 369.9 & 370.1 & 147.8 & 4 & PVC & $s$ & $9 / 6 / 88$ & \\
\hline AMB7A & $M w$ & $\mathrm{PI}$ & 103987.1 & 51591 & 125.6 & 115.6 & 371.6 & $373 . \overline{6}$ & 373.8 & 258 & 4 & $\overrightarrow{P V C}$ & $S$ & $7 / 26 / 91$ & \\
\hline AMB7B & $\overline{M w}$ & $\mathrm{PI}$ & 103972 & 51590.3 & 162.9 & 152.9 & 370.9 & 373 & 373.1 & 220.1 & 4 & PVC & $S$ & $7 / 26 / 91$ & \\
\hline AMBBD & $\overline{M w}$ & PI & 103874.7 & 51400.5 & 240.8 & 220.8 & 367.8 & 369.6 & 369.9 & 148.8 & 4 & PVC & $\mathrm{s}$ & $10 / 31 / 89$ & \\
\hline$\overline{A M B 9 D}$ & $\overline{M w}$ & $\mathrm{Pl}$ & 103585.2 & 51263 & 239.7 & 219.7 & 365.7 & $367 . \overline{9}$ & 368.1 & 148.2 & 4 & $\bar{P} V \bar{C}$ & $\ddot{s}$ & $10 / 25 / 89$ & \\
\hline AMB10A & $\mathrm{Mw}$ & PI & 103326.4 & 51410 & 111.4 & 106.4 & 364.4 & 366.5 & 366.6 & 260.1 & 4 & $\overline{\mathrm{PVC}}$ & $\mathrm{s}$ & $8 / 26 / 91$ & \\
\hline AMB10B & $\mathrm{Mw}$ & PI & 103337.3 & 51418.3 & 154.3 & 149.3 & 364.3 & 366.4 & 366.6 & 217.1 & 4 & PVC & $S$ & $9 / 3 / 91$ & \\
\hline
\end{tabular}




\begin{tabular}{|c|c|c|c|c|c|c|c|c|c|c|c|}
\hline \multicolumn{12}{|c|}{ TABLE D Partial listing of Screen Zone ARC/INFO coverage point attribute table (ctd.) } \\
\hline & & & & & & & & & & & \\
\hline PLANE1 & PLANE2 & PLANE3 & PLANE4 & PLANE5 & PLANE6 & PLANE7 & PLANE8 & SZTOP_AQFR & SZBOT AQFR & BREACH & \\
\hline-168 & 43.4 & 60.5 & 82.3 & 116.7 & 169.3 & \begin{tabular}{|l|}
170.4 \\
\end{tabular} & 356.3 & M-AREA & M-AREA & NO & \\
\hline .168 & 43.4 & 60.5 & 82.3 & 116.7 & 169.4 & 170.6 & 356.1 & M-AREA & M-AREA & NO & \\
\hline .167 .1 & 43.1 & 58.3 & 80.6 & 115.3 & 188.7 & 169.9 & 360 & M-AREA & M-AREA & NO & \\
\hline-167.2 & 43.1 & 58.4 & 80.7 & 115.3 & 168.7 & 169.9 & 359.9 & M.AREA & M-AREA & NO & \\
\hline-166.5 & 44.3 & 59.9 & 82.2 & 117.5 & 172.7 & 174.7 & 350.5 & M-AREA & M-AREA & NO & \\
\hline .168 .5 & 44.2 & 59.9 & 82.2 & 117.5 & 172.5 & 174.5 & 350.9 & $\mathrm{LL}$ & $\mathrm{LL}$ & NO & \\
\hline-168.5 & 42.3 & 58.7 & 80.7 & 114.8 & 166.2 & 166.9 & 361.7 & M-AREA & M-AREA & NO & \\
\hline-168.5 & 42.3 & 58.8 & 80.7 & 114.8 & 166.3 & 167 & 361.7 & M-AREA & M-AREA & NO & \\
\hline-166.5 & 43.4 & 58 & 80.5 & 115.4 & 169.6 & 170.9 & 359.9 & M-AREA & M-AREA & NO & \\
\hline .169 & 41.6 & 58 & 80 & 113.8 & 164.6 & 165.3 & 363.8 & M-AREA & M-AREA & NO & \\
\hline-166.9 & 43 & 57.6 & 80 & 114.6 & 168.2 & 169.1 & 363.6 & M-AREA & M-AREA & NO & \\
\hline .166 .8 & 43 & 57.6 & 80.1 & 114.7 & 168.3 & 169.2 & 363.1 & M-AREA & M-AREA & NO & \\
\hline .112 .4 & 90.6 & 97.9 & 133.2 & 138.3 & 195.9 & 212.2 & 325.9 & M-AREA & $\mathrm{LL}$ & YES & \\
\hline-130.5 & 73.2 & 86.6 & 107.2 & 118.2 & 189.7 & 194.5 & 277.1 & $\mathrm{LL}$ & $\overline{L L}$ & NO & \\
\hline-130.5 & 73.1 & 86.5 & 107.2 & 118.2 & 189.7 & 194.5 & 277.4 & M-AREA & M-AREA & NO & \\
\hline .126 .8 & 38.2 & 65.3 & 107.6 & 127.8 & 185.4 & 191.6 & 345.5 & LL & LL & NO & \\
\hline .126 .7 & 38.3 & 65.4 & 107.8 & 127.8 & 185.3 & 191.5 & 345.2 & M-AREA & M-AREA & NO & \\
\hline-153.7 & 65 & 75 & 93.2 & 113,6 & 170.9 & 171.9 & 298.9 & LL & LL. & NO & \\
\hline-153.6 & 65.1 & 75.1 & 93.3 & 113.6 & 170.9 & 171.9 & 298.9 & M-AREA & M-AREA & NO & \\
\hline-133.1 & 69.7 & 105.6 & 936.5 & 140.6 & 205.7 & 212.8 & 357.3 & M-AREA & M-AREA & NO & \\
\hline-133.9 & 67.2 & 107.7 & 134 & 138.7 & 201.8 & 208.1 & 348.6 & M-AREA & GCCU & YES & \\
\hline-135.3 & 65.5 & 111.5 & 132.5 & 137.6 & 198,4 & 204.3 & 348 & M-AREA & M-AREA & NO & \\
\hline-134.8 & 66.8 & 110.9 & 134.3 & 138.5 & 201.2 & 207.3 & 354.9 & M-AREA & M-AREA & NO & \\
\hline-126.3 & 73.9 & 94.4 & 131.4 & 149.3 & 213.6 & 220.5 & 382 & MSCBCU & MSCBCU & NO & \\
\hline .126 .2 & 73.8 & 94.4 & 131.3 & 149.4 & 213.4 & 220.3 & 382 & LL & $\mathrm{LL}$ & NO & \\
\hline-126.2 & 73.7 & 94.4 & 131.2 & 149.5 & 213.3 & 220.1 & 381.9 & M-AREA & GCCU & YES & \\
\hline-126.5 & 74.1 & 94.2 & 131.7 & 149.1 & 213.8 & 221 & 382 & M-AREA & M-AREA & NO & \\
\hline-126.7 & 74.4 & 94 & 132.1 & 149 & 214.1 & 221.5 & 381.8 & M-AREA & M-AREA & NO & \\
\hline-127 & 73.4 & 92.5 & 132.9 & 149 & 213.1 & 221 & 377.4 & M-AREA & M-AREA & NO & \\
\hline-126.7 & 73.5 & 92.8 & 132.3 & 149.2 & 213.2 & 220.9 & 379.1 & MSCBCU & $\mathrm{MSCBCU}$ & NO & \\
\hline .126 .8 & 73.6 & 92.8 & 132.5 & 149.1 & 213.3 & 221 & 379 & $\mathrm{LL}$ & LL & NO & \\
\hline-127.5 & 75.5 & 93.9 & 133.8 & 148.2 & 214.8 & 223 & 380.1 & M-AREA & GCCU & YES & \\
\hline-129 & 77.4 & 93.5 & 137.1 & 147 & 216 & 225.5 & 376.5 & M-AREA & GCCU & YES & \\
\hline .129 .9 & 75.9 & 94.4 & 138.5 & 146.3 & 214,3 & 223.9 & 370 & MSCBCU & MSCBCU & NO & \\
\hline-129.8 & 75.9 & 94.2 & 138.4 & 146.4 & 214.4 & 223.9 & 370.1 & $\mathrm{LL}$ & LL & NO & \\
\hline
\end{tabular}


WSRC-TR-96-0324

TABLE E Description of attributes of Screen Zones coverage PAT 
Table E. Description of Attributes for the Screen Zone Coverage Point Attribute Table (PAT)

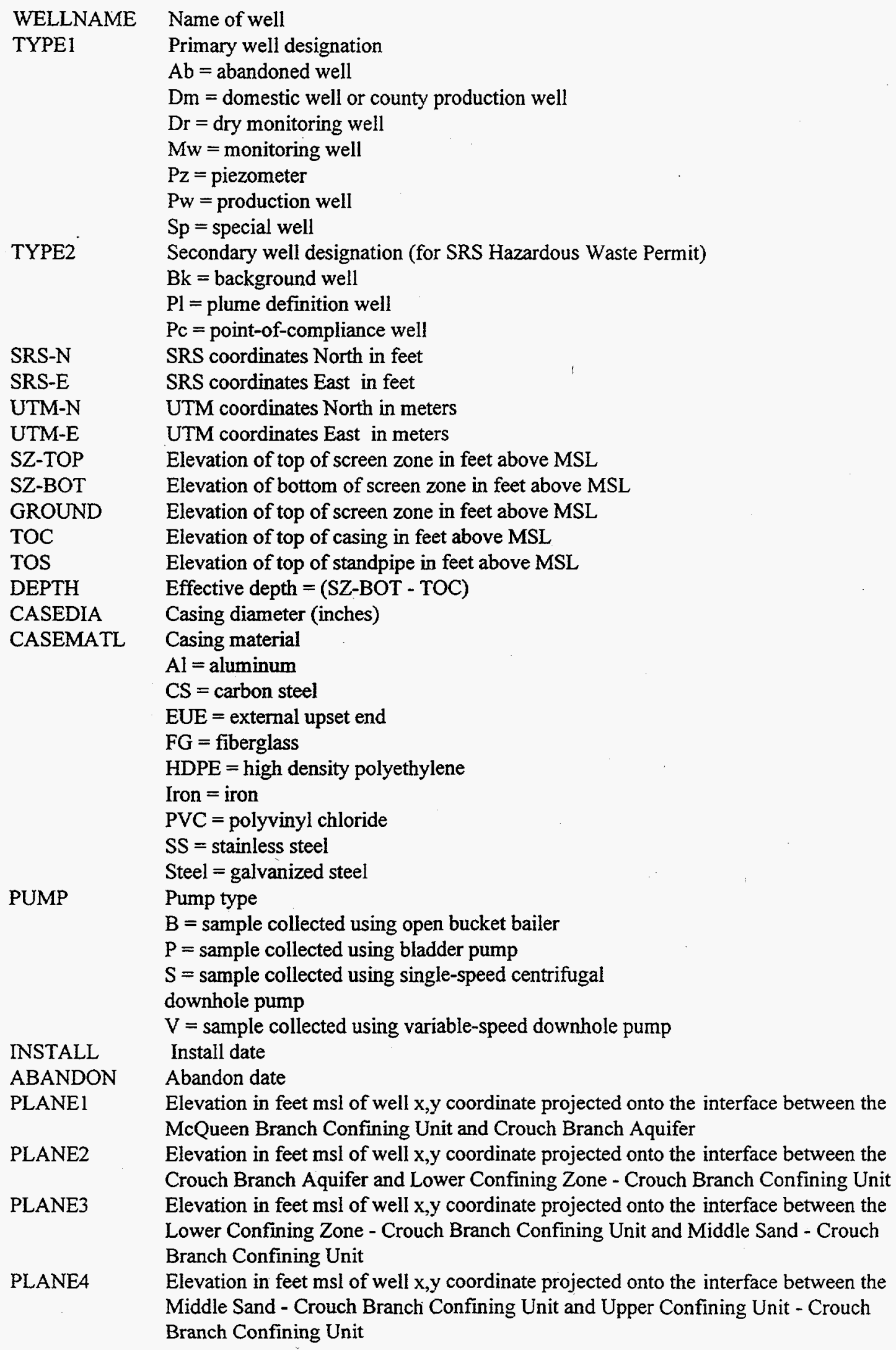


Table E Continued. Description of Attributes for the Screen Zone Coverage

PLANE5 Elevation in feet msl of well $x, y$ coordinate projected onto the interface between the Upper Confining Zone - Crouch Branch Confining Unit and Lost Lake Aquifer

PLANE6 Elevation in feet msl of well $x, y$ coordinate projected onto the interface between the Lost Lake Aquifer and Green Clay ConfiningUnit

PLANE7 Elevation in feet msl of well $x, y$ coordinate projected onto the interface between the Green Clay Confining Unit and M-Area Aquifer

PLANE8 Elevation in feet msl of well $x, y$ coordinate projected onto the Land Surface

SZTOP-AQFR Hydrostratigraphic unit containing the top of the screen:

CB - Lower Confining Zone - Crouch Branch Aquifer

$\mathrm{CBCU}$ - Crouch Branch Confining Unit

GCCU - Green Clay Confining Unit

LL - Lost Lake

M-Area - M-Area Aquifer

MCQUEEN - Below the Crouch Branch Aquifer

MSCBCU - Middle Sand - Crouch Branch Confining Unit

UCCBCU - Upper Confining Zone - Crouch Branch Confining Unit

SZBOT-AQFR Hydrostratigraphic unit containing the bottom of the screen:

$\mathrm{CB}$ - Lower Confining Zone - Crouch Branch Aquifer

$\mathrm{CBCU}$ - Crouch Branch Confining Unit

GCCU - Green Clay Confining Unit

LL - Lost Lake

M-Area - M-Area Aquifer

MCQUEEN - Below the Crouch Branch Aquifer

MSCBCU - Middle Sand - Crouch Branch Confining Unit

BREACH

UCCBCU - Upper Confining Zone - Crouch Branch Confining Unit Indicates potential breach of confining unit:

YES - potential breach

NO - potential breach not present 
WSRC-TR-96-0324

TABLE F Description of attributes for the annular material coverage PAT 
Table F. Description of Attributes for the Annular Materials Coverage Point Attribute Table (PAT)

X-COORD: SRS coordinates East in feet

Y-COORD: $\quad$ SRS coordinates North in feet

WELL-ID: Name of well

WELLUSE: Use of well

AN_TOP_MSL Elevation of top of annular materials in feet above mean sea level

AN_BOT_MSL Elevation of bottom of annular materials in feet above mean sea level

AN_CODE Primary description of well annular materials:

BF - Back Fill

FP - Filter Pack

FS - Fine Sand Seal

AN_DESC Specific description of AN_CODE material:

Cuttings

Filtersand

Finesand

Holeplug - Material placed at the bottom of the well hole

Nodata - annular materials data not in GIMS

Sand

Sand/Bentonite

PLANE1 Elevation in feet msl of well $x, y$ coordinate projected onto the interface between the McQueen Branch Confining Unit and Crouch Branch Aquifer

PLANE2 Elevation in feet msl of well $x, y$ coordinate projected onto the interface between the Crouch Branch Aquifer and Lower Confining Zone - Crouch Branch Confining Unit

PLANE3 Elevation in feet msl of well $\mathrm{x}, \mathrm{y}$ coordinate projected onto the interface between the Lower Confining Zone - Crouch Branch Confining Unit and Middle Sand - Crouch Branch Confining Unit

PLANE4 Elevation in feet $\mathrm{msl}$ of well $\mathrm{x}, \mathrm{y}$ coordinate projected onto the interface between the Middle Sand - Crouch Branch Confining Unit and Upper Confining Unit - Crouch Branch Confining Unit

PLANE5 Elevation in feet msl of well $\mathrm{x}, \mathrm{y}$ coordinate projected onto the interface between the Upper Confining Zone - Crouch Branch Confining Unit and Lost Lake Aquifer

PLANE6 Elevation in feet msl of well $\mathrm{x}, \mathrm{y}$ coordinate projected onto the interface between the Lost Lake Aquifer and Green Clay Confining Unit

PLANE7 Elevation in feet msl of well $\mathrm{x}, \mathrm{y}$ coordinate projected onto the interface between the Green Clay Confining Unit and M-Area Aquifer

PLANE8 Elevation in feet msl of well $\mathrm{x}, \mathrm{y}$ coordinate projected onto the Land Surface

ANTOP-AQFR Hydrostratigraphic unit containing the top of the annular materials zone:

$\mathrm{CB}$ - Lower Confining Zone - Crouch Branch Aquifer

$\mathrm{CBCU}$ - Crouch Branch Confining Unit

GCCU - Green Clay Confining Unit

LL - Lost Lake

M-Area - M-Area Aquifer

MCQUEEN - Below the Crouch Branch Aquifer

MSCBCU - Middle Sand - Crouch Branch Confining Unit

UCCBCU - Upper Confining Zone - Crouch Branch Confining Unit 
Table F Continued. Description of Attributes for the Annular Materials Coverage

ANBOT-AQFR Hydrostratigraphic unit containing the bottom of the annular materials zone:

$\mathrm{CB}$ - Lower Confining Zone - Crouch Branch Aquifer

$\mathrm{CBCU}$ - Crouch Branch Confining Unit

GCCU - Green Clay Confining Unit

LL - Lost Lake

M-Area - M-Area Aquifer

MCQUEEN - Below the Crouch Branch Aquifer

MSCBCU - Middle Sand - Crouch Branch Confining Unit

UCCBCU - Upper Confining Zone - Crouch Branch Confining Unit

BREACH Indicates potential breach of confining unit

YES - potential breach

NO - potential breach not present 
WSRC-TR-96-0324

Table G Partial listing of records for combined annular materials 


\begin{tabular}{|c|c|c|c|c|c|c|c|c|c|c|c|c|c|c|}
\hline \multicolumn{8}{|c|}{ TABLE G } & & & & & & & \\
\hline Well-id & Welluse & An top ms/1 & An bot msl1 & An code1 & An desc1 & Antop_aqfr1 & Anbot_aqfr1 & An top $\mathrm{ms} / 2$ & $\mathrm{An}$ bot $\mathrm{ms} / 2$ & An code? & An desc? & & & \\
\hline$A B P 3 C$ & MONITORING & $\begin{array}{r}172.7 \\
\end{array}$ & 170.3 & FS & FINESAND & GCCU & LL & 170.3 & 144.3 & FP & SAND & $\mathrm{LL}$ & Anvo__aqir & \begin{tabular}{|l} 
Breach \\
YES
\end{tabular} \\
\hline$A B P 8 C$ & MONITORING & 196.9 & 194.9 & FS & FINESAND & M-AREA & M-AREA & 194.9 & 149.8 & FP & SAND & M-AREA & $\mathrm{LL}$ & YES \\
\hline$\overline{\mathrm{ABW} 1}$ & MONITORING & 229.1 & 185.1 & FP & NODATA & M-AREA & $\mathrm{LL}$ & -999 & .999 & & & & & YES \\
\hline $\mathrm{ACB2A}$ & MONITORING & 242.8 & 207.8 & FP & NODATA & M-AREA & GCCU & -999 & -999 & & & & & YYES \\
\hline AMB10B & MONITORING & 162.7 & 159.7 & FS & FINESAND & $L L$ & LL & 159.7 & 141.3 & FP & FILTERSAND & $\mathrm{LL}$ & UCCBCU & YES \\
\hline AMB12D & MONITORING & 249.2 & 245.3 & FS & NODATA & M-AREA & M-AREA & 245.3 & 208.7 & FP & SAND & M-AREA & LL & YES \\
\hline AMBAA & MONITORING & 132.8 & 130,3 & $\overline{F S}$ & FINESAND & UCCBCU & MSCBCU & 130.3 & 114.3 & FP & FILTERSAND & MSCBCU & MSCBCU & YES \\
\hline AMB $\bar{B}$ & MONITORING & 163.8 & 161.3 & FS & FINESAND & $\overline{L L}$ & $L L$ & 161.3 & 145.3 & FP & FILTERSAND & LL & UCCBCU & YES \\
\hline AMB4D & MONITORING & 240.4 & 212.4 & FP & FILTERSAND & M-AREA & LL & -999 & -999 & & & & & YYES \\
\hline AMB7A & MONITORING & 132.6 & 110.6 & FP & FILTERSAND & UCCBCU & MSCBCU & -999 & -999 & & & & & YES \\
\hline AMB7B & MONITORING & 170.3 & 145.9 & FP & FILTERSAND & LL & UCCBCU & -999 & .999 & & & & & YES \\
\hline ARP2 & MONITORING & 235.3 & 232.3 & FS & NODATA & M-AREA & M-AREA & 232.3 & 190.3 & FP & NODATA & M-AREA & LL & YES \\
\hline ARP3 & MONITORING & 226.2 & 223.2 & FS & NODATA & M-AREA & M-AREA & 223.2 & 188.2 & FP & NODATA & M-AREA & GCCU & YES \\
\hline ASB $8 A$ & MONITORING & 90.2 & 86.2 & FS & NODATA & MSCBCU & MSCBCU & 86.2 & 69.2 & FP & NODATA & MSCBCU & CBCU & YES \\
\hline ASB8B & MONITORING & 136.6 & 130.6 & FS & NODATA & $\mathrm{LL}$ & MSCBCU & 130.6 & 112.6 & FP & NODATA & MSCBCU & MSCBCU & YYES \\
\hline$A S B B C$ & MONITORING & 198.6 & 190.6 & FS & NODATA & GCCU & LL & 190.6 & 172.6 & FP & NODATA & $\overline{\mathrm{LL}}$ & LL & YES \\
\hline MHT10B & MONITORING & 203.9 & 201.8 & FS & FINESAND & GCCU & GCCU & 201.8 & 186.7 & FP & SAND & GCCU & $\mathrm{LL}$ & YES \\
\hline MHT10C & MONITORING & 215.1 & 213.9 & FS & FINESAND & M-AREA & M-AREA & 213.9 & 203.9 & FP & SAND & M-AREA & GCCU & YES \\
\hline MHT11C & MONITORING & 222.3 & 219.6 & FS & FINESAND & M.AREA & M-AREA & 219.6 & 200.2 & FP & SAND & M-AREA & GCCU & YES \\
\hline MHT12C & MONITORING & 220.8 & 218.4 & FS & FINESAND & M-AREA & M-AREA & 218.4 & 202.9 & FP & SAND & M-AREA & GCCU & YES \\
\hline MHT13D & MONITORING & 237.6 & 235.7 & FS & FINESAND & M-AREA & M-AREA & 235.7 & 208.4 & FP & SAND & M-AREA & GCCU & YES \\
\hline MHT14D & MONITORING & 238.4 & 236.1 & FS & FINESAND & M-AREA & M-AREA & 236.1 & 206.6 & $\mathrm{FP}$ & SAND & M-AREA & GCCU & YES \\
\hline MHT17C & MONITORING & 209.6 & 199.4 & FP & SAND & M-AREA & GCCU & -999 & .999 & & & & & YES \\
\hline MHTIC & MONITORING & 214.4 & 211.6 & FS & FINESAND & M-AREA & M-AREA & 211.6 & 200.7 & FP & SAND & M-AREA & GCCU & YES \\
\hline MHT20C & MONITORING & 208.3 & 207.9 & FS & FINESAND & M-AREA & M-AREA & 207.9 & 201.4 & $F P$ & SAND & M-AREA & GCCU & YES \\
\hline MHT2C & MONITORING & $\quad 217.7$ & 215.5 & FS & FINESAND & M-AREA & M-AREA & 215.5 & 202.1 & FP & SAND & M-AREA & GCCU & YES \\
\hline MHT3C & MONITORING & 213.9 & 212.9 & FS & FINESAND & M-AREA & M-AREA & 212.9 & 200.6 & FP & SAND & M-AREA & GCCU & YES \\
\hline MHT4C & MONITORING & 217.8 & 216.5 & FS & FINESAND & M-AREA & M-AREA & 216.5 & 203.4 & FP & SAND & M-AREA & GCCU & YES \\
\hline MHT5C & MONITORING & 217.5 & 215.4 & FS & FINESAND & M-AREA & M-AREA & 215.4 & 202.1 & $\mathrm{FP}$ & SAND & M-AREA & GCCU & YES \\
\hline MHTGC & MONITORING & 216.8 & 215.6 & FS & FINESAND & M-AREA & M-AREA & 215.6 & 201.6 & $F P$ & SAND & M-AREA & GCCU & YES \\
\hline MHT7C & MONITORING & 217.6 & 216.8 & FS & FINESAND & M-AREA & M-AREA & 216.9 & 201 & $F P$ & SAND & M-AREA & GCCU & YES \\
\hline MHTBC & MONITORING & 216.6 & 215 & FS & FINESAND & M-AREA & M-AREA & 215 & 202.3 & FP & SAND & M-AREA & GCCU & YES \\
\hline MHT9B & MONITORING & 203 & 201 & FS & FINESAND & GCCU & $\overline{L L}$ & 201 & 185.3 & FP & SAND & $\mathbf{L L}$ & LL & YES \\
\hline MHT9C & MONITORING & 217.7 & 216.1 & FS & FINESAND & M-AREA & M-AREA & 216.1 & 206.2 & $\mathrm{FP}$ & SAND & M-AREA & GCCU & YES \\
\hline$\overline{M S B 1 B}$ & MONITORING & 147.8 & 146 & $\overline{F S}$ & FINESAND & $\overline{\mathrm{LL}}$ & LL. & 146 & 131.9 & FP & SAND & $\overline{\mathrm{LL}}$ & UCCBCU & YES \\
\hline $\mathrm{MSB} 21 \mathrm{~B}$ & MONITORING & 154.4 & 151.5 & FS & NODATA & LI & $\mathrm{LL}$ & 151.5 & 133.4 & FP & SAND & LL & UCCBCU & YES \\
\hline$\overline{\mathrm{MS}} \overline{\mathrm{B}} 29 \mathrm{~A}$ & MONITORING & $\overline{134.9}$ & 128.9 & FS & NODATA & UCCBCU & UCCBCU & 128.9 & 112.9 & $F \bar{P}$ & NODATA & UCCBCU & $\overline{M S C B} \overline{C U}$ & YES \\
\hline$\overline{M S B} 29 D$ & MOONITORING & 236.6 & 233.6 & $\overline{F S}$ & NODATA & M-AREA & M-AREA & 233.6 & 197.6 & $\overline{F P}$ & NODATA & M-AREA & $\mathrm{LL}$ & YES \\
\hline
\end{tabular}


Table $\mathrm{H} \quad$ List of analytes used in screening 


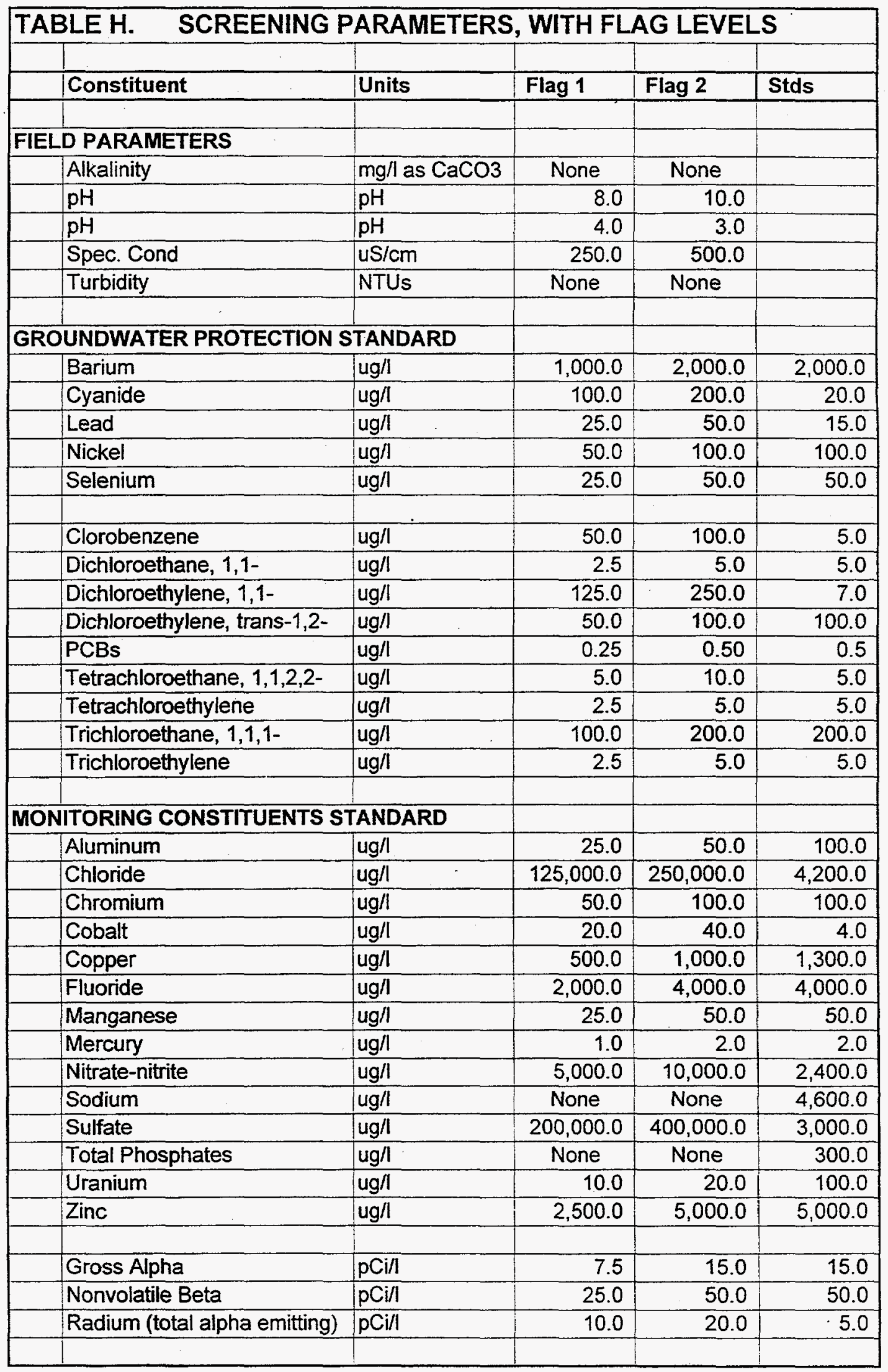

